David Neild

\title{
Vindicatory Damages in the Child Welfare Tort Cases
}

\author{
LLM THESIS \\ LAWS 591
}

FACULTY OF LAW

TE WHARE WĀNANGa O TE ŪPOKO O TE IKA A MĀUI

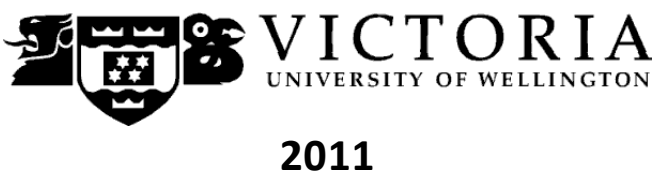




\section{Acknowledgements}

This thesis marks the end of a wonderful year of study to which a number of people have contributed. Lukas Schroeter first suggested I enroll in Victoria's LLM course, and parts of the thesis continue conversations we had when students in Geoff's advanced torts class. Frances Gush, Zoe Lawton and Anna Skellern all read parts of the thesis and their comments and our discussions were invaluable. I am indebted to my sister Susannah for making sure I ate during the last month before hand in.

I was fortunate to study at Victoria while Tracy Thomas was subject librarian at the law library. The hours spent in her office discussing Westlaw and Lexis were an unlikely highlight during my years at law school. Her knowledge of legal databases is matched by her enthusiasm and generosity in imparting it to students.

During most of my masters I shared a study room with Danica McGovern. Sharing an office with a friend and getting work done is not easy but somehow Danica managed to keep me on track, and over the year we lived through each others' theses. She now knows much more about vicarious liability than she ever wanted to, while I often startle friends with my knowledge of the effects of sexual violence and the way in which victim impact statements might empower victims. It was usually Danica who suffered the first draft of anything I wrote, most of which got deleted before anyone else saw it.

My greatest debt is to my two sterling supervisors: Professors Geoff McLay and Bill Atkin. I worked for both of them as a research assistant, and this thesis is really one project among many on which we worked together in one capacity or another over the last year and a half, including textbook chapters on NZBORA and tort damages and a case book on tort law. Their approach to the projects for which I was research assistant was always generously collaborative. I was able to learn from the approach they took to research, writing, and deadlines - there were lessons on what to do and what not to do. A great part of this thesis developed during conversations over sausage rolls and coffee or through discussions concerning other projects I happened to be working on. Of their many beyond the call of duty kindnesses two stand out: Geoff letting me housesit while he was away (chapter VI was written in the company of his very friendly shih tzu poodle Cocoa); and Bill driving me to and from the printers on the day it was due (it was handed in with twenty minutes to spare). 
Table of Contents

I Introduction

A The Original Contribution of this Thesis........................................................................

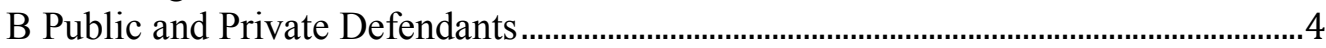

C Structure of this Thesis ..................................................................................................

II Vindication as an Alternative to Compensation.................................................................

A Are These Cases about shifting loss?........................................................................

B The Compensation Conception of Tort Law ...................................................................

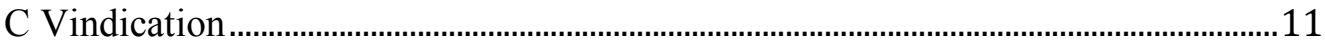

1 Damages for the wrong rather than the loss …...........................................................12

2 The public law aspect of vindication ………................................................................14

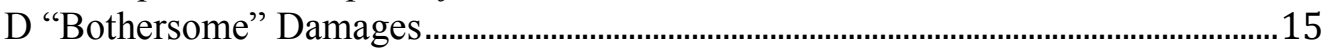

E Can Vindication be Achieved through Litigation?......................................................17

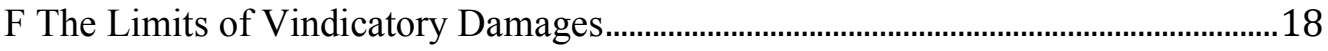

G The Accident Compensation Bar................................................................................20

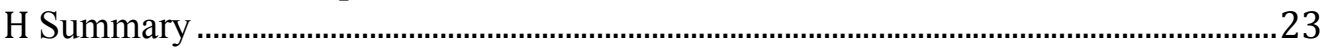

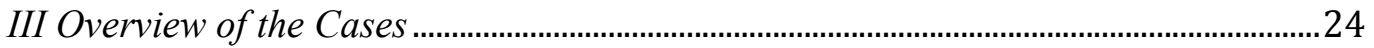

A Overview of New Zealand Cases ............................................................................. 24

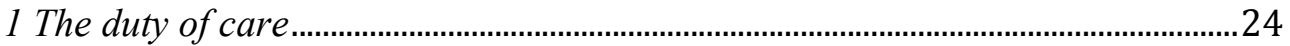

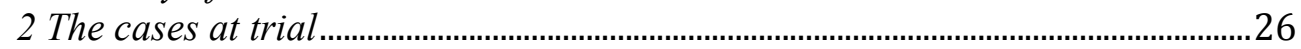

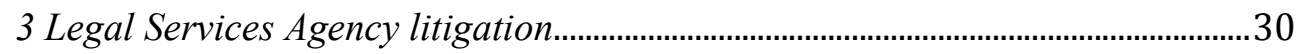

B The English Cases ...................................................................................................... 31

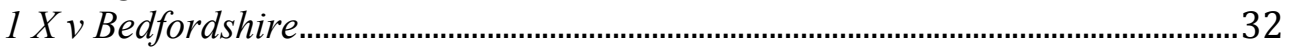

2 The European Court of Human Rights' decision on damages .............................. 33

3 The English development of the duty of care after Z .................................................35

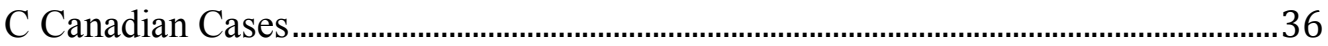

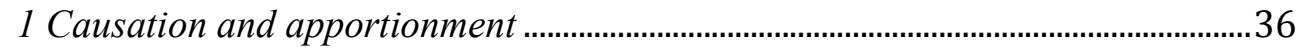

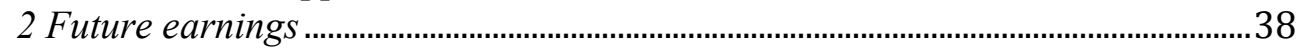

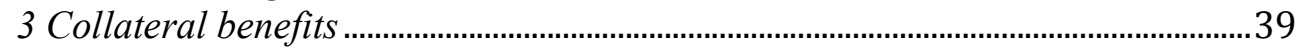

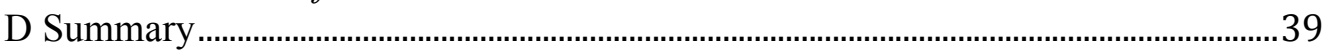

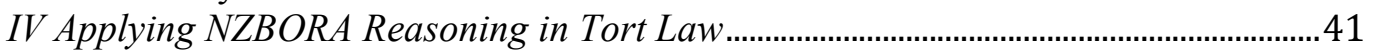

A The Line between "Public" and "Private" Law ............................................................. 42

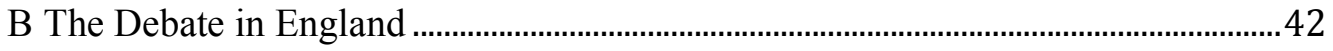

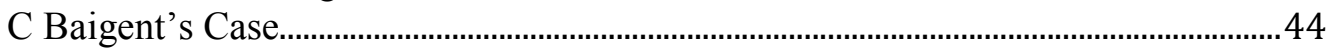

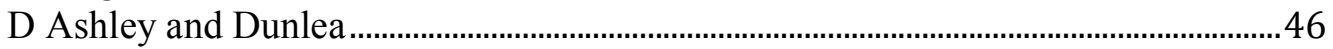

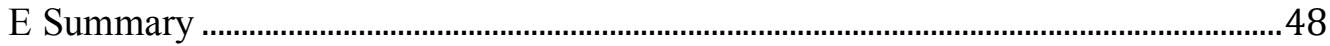

V Support for Vindicatory Damages within Existing Tort Law .......................................50

A: Trespass to the Person and Negligence.....................................................................50

B Support for a Non-compensatory Approach in Negligence...........................................53

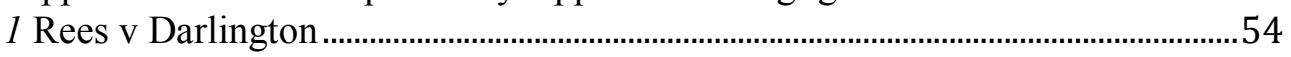

2 The advantages of Nolan's approach ………….........................................................55

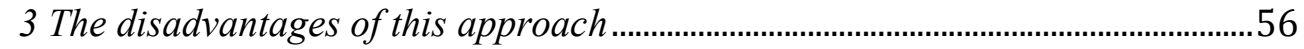

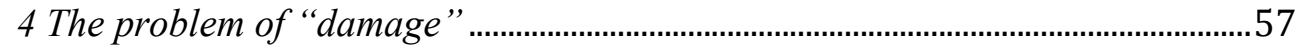

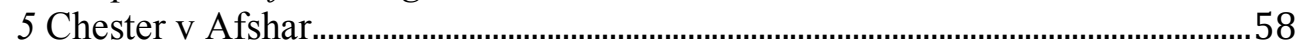

C Existing Separate Awards of Non-compensatory Damages in Tort Law................60

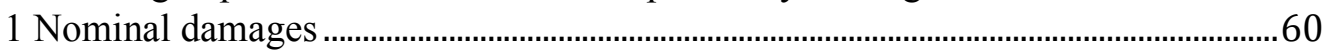

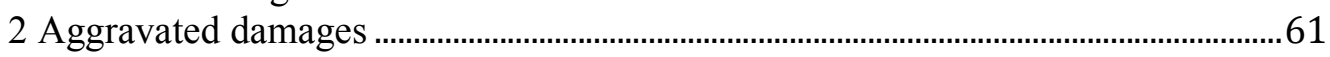

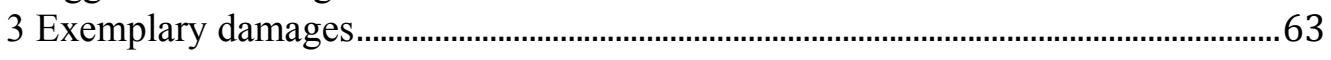

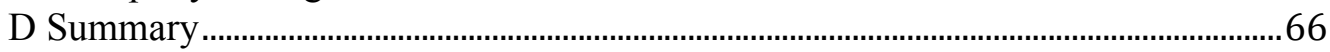




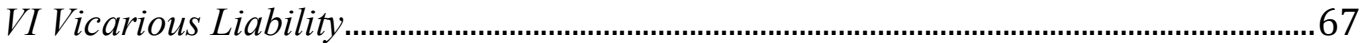

A The Argument Against Vindicatory Damages for Vicarious Liability ...................67

B Two Counter-arguments...............................................................................................68

C The Child Welfare Cases and Fault ..........................................................................69

D The Original Test: the Relationship between the Defendant and Wrongdoer.......70

E Course of Employment ...................................................................................................... 71

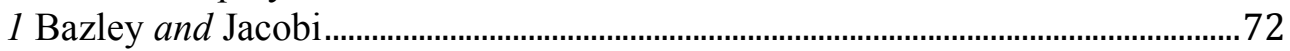

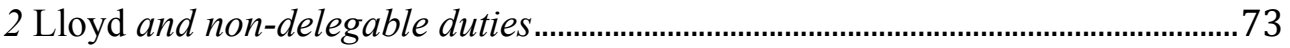

3 Lewis and independent contractors..................................................................... 74

4 Bazley and Jacobi explained with non-delegable duties .........................................75

5 Lister and assumption of responsibility ...................................................................... 76

F Stretching the Employment Relationship: S v Attorney-General..............................77

1 Is agency an established ground of vicarious liability? .........................................78

2 Non-delegable duties applied to S v Attorney-General ..........................................79

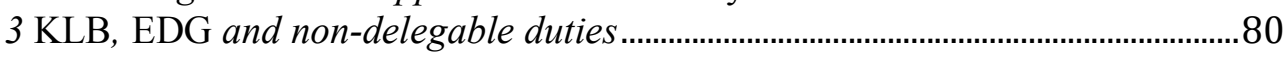

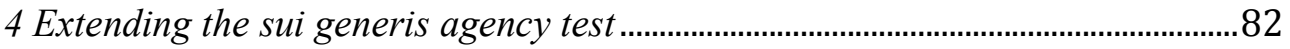

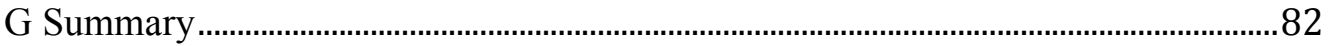

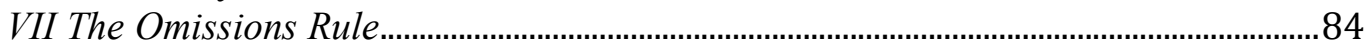

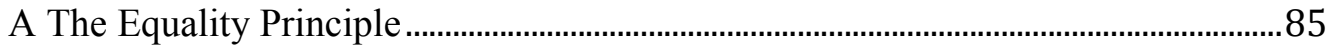

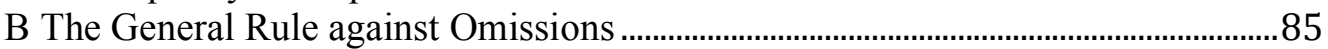

C The Difficulty of Distinguishing between an Act and an Omission.........................86

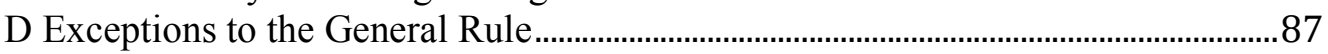

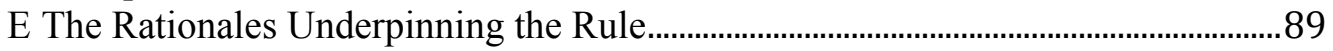

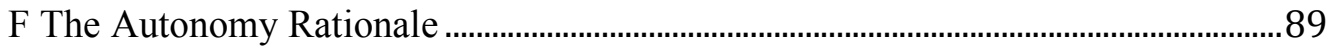

G The Loss Distribution Rationale and Cost-benefit Analyses .................................... 94

H Does the End Justify the Means?................................................................................ 97

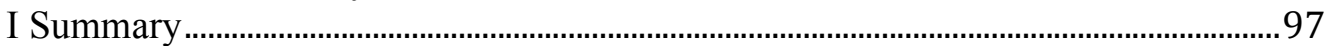

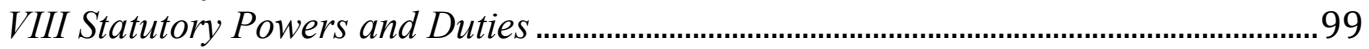

A The East Suffolk or Private Law Approach.................................................................. 100

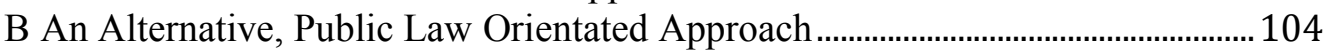

C The New Zealand Approach: an Uneasy Compromise .............................................. 105

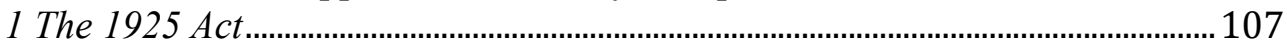

2 The 1989 Act ................................................................................................................... 107

D The Disagreement about Anns and the Private Law Remedy for a Public Law

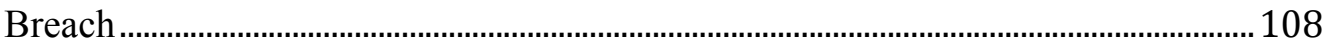

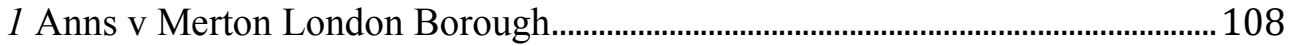

2 Stovin v Wise and Gorringe .................................................................................. 109

E The East Suffolk Approach and Parliamentary Intention......................................... 111

F Vindicating the Negligent Exercise of Statutory Power through Tort Law......... 113

G Justiciability......................................................................................................................... 114

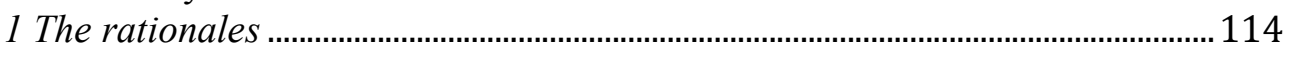

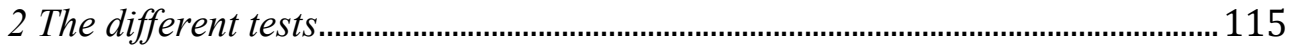

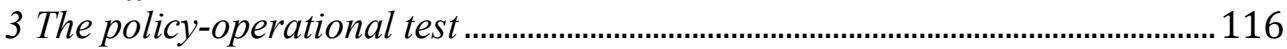

4 Wednesbury unreasonableness ..............................................................................117

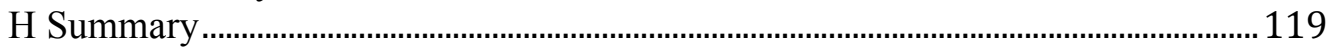

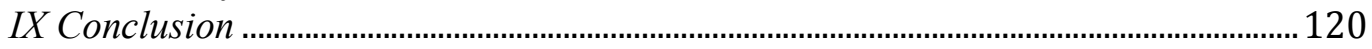




\begin{abstract}
This thesis argues that vindicatory damages should be available in the child welfare tort cases against public authorities. These are cases in which the plaintiffs sue public authorities either for not protecting them from harm when they were children, or where it is alleged that the authority's employees abused the children while in its care. Vindicatory damages would be intended to mark the wrong to the plaintiff, rather than attempting to compensate the consequences. This thesis argues in support of the availability of a separate head of vindicatory damages in tort law, including negligence, and explores some of the liability issues which arise in these cases, including vicarious liability, liability for omissions and liability in negligence for the way in which a statutory power is exercised or for a breach of a statutory duty. New Zealand's accident compensation scheme is also discussed: it is argued that vindicatory damages in tort law should not be barred by the scheme.
\end{abstract}

\title{
Word length
}

The text of this paper (excluding abstract, table of contents, footnotes and bibliography) comprises approximately 46,200 words.

\section{Subjects and Topics}

Tort Damages

Vindicatory Damages

NZBORA Damages

Crown Liability

Vicarious Liability 


\section{Introduction}

This thesis argues that non-loss based vindicatory damages should be available in tort law. It does this by analysing cases in which children have sued public authorities, either for failing to protect them, or because the authority's employees abused them. The reason for using these cases is that they do not fit the way in which tort law is most often thought of, as a vehicle for shifting loss from the plaintiff to the defendant. ${ }^{1}$ In these cases, therefore, an award to mark but not to compensate the wrong is appropriate.

One example of the difficulty which arises from thinking of these cases as concerned with shifting loss is the 2005 Supreme Court of Canada case $H L .^{2}$ The plaintiff had been sexually abused as a child on a federal reserve by the government's residence administrator. The plaintiff claimed that his inability to maintain employment as an adult had been caused by his alcoholism, which the trial judge found was caused by the abuse. The Court upheld the judge's award for loss of income, although it set aside the part of the award for the lost income which might have been earned had the plaintiff not been incarcerated.

$H L$ was analysed by the Court as a typical tort case, in which damages are intended to put the plaintiff in the position in which he or she would have been "but for" the abuse. In New Zealand, of course, loss caused by sexual abuse is usually recoverable under New Zealand's statutory compensation scheme, and the plaintiff is barred from suing for additional compensatory damages in tort. $^{3}$ However, even in the Canadian case the plaintiff had received social assistance payments while he was unemployed, which were deducted as a "collateral benefit" from the damages award.

Rather than allocating loss, the child welfare cases are better analysed as addressing public law concerns: the relationship between the state and vulnerable individuals, the role of the state as representative of the community, and the duties of the community to its children. In order to reflect these public law concerns, separate non-compensatory damages should be available in tort law to "vindicate" the underlying obligation to protect children, without focusing on the loss caused by the wrong and, in New Zealand, without being barred by the statutory compensation scheme.

It is not argued that tort law is the best mechanism for providing compensation against the state for child abuse, and this thesis does not deal with the claim that narrating their story in

\footnotetext{
${ }^{1}$ This paradigm is explained in more detail in chapter two.

${ }^{2}$ HL v Canada (Attorney-General) 2005 SCC 25, [2005] 1 SCR 401. This case is discussed is more detail in chapter three, at the text to footnote 69.

${ }^{3}$ Discussed in chapter two.
} 
court might be therapeutic for victims. ${ }^{4}$ Government controlled schemes such as the Care Claim and Resolution team (discussed below) and the more independent ombudsman, are arguably better methods for dealing with the cases discussed. ${ }^{5}$ This thesis makes the more modest claim that there is a place within tort law for an award through which the judiciary can recognise government wrongs, and mark them with an award of damages. These damages would not be calculated by analysing the loss which the claimant suffered, but would be designed to vindicate the rights of the plaintiff or the duties of the defendant.

This approach is consistent with Linden's description of tort law as, among other things, an ombudsman: ${ }^{6}$

Tort law is an ombudsman. It can be used to apply pressure upon those who wield political, economic or intellectual power; in short, it empowers the injured ... The damage sought in such a case may not be of primary concern to the plaintiff; the main goal may be to stimulate administrative action or expose wrongdoing. Recent evidence of this tendency is that some of the 9/11 families, who rejected the US government compensation, and chose instead to sue, were partially motivated, at least, "by a strong sense of duty to act as an agent of the community to gain information about what happened, to hold people accountable and to play a role in prompting responsive change."

Tort law can be used to reveal facts, and through exposing wrongdoing may even prompt government inquiries, arguably a more useful way of addressing historic abuse. It is the utility of tort law in uncovering wrongdoing and providing a marker through an award of damages which underpins the approach in this thesis. Some wrongs need to be vindicated even though there is no loss, or the loss is impossible to quantify.

\section{A The Original Contribution of this Thesis}

The contribution of this thesis concerns the public law aspect of damages rather than the way tort law might help child abuse victims. The child welfare cases are analysed as examples of the way tort actions, including negligence, fulfil a public law role within the common law. This raises the question whether tort law includes an appropriate remedy to reflect this public law approach. Vindicatory damages have the potential to avoid problems associated with

\footnotetext{
${ }^{4}$ There is a separate literature on whether tort law can be therapeutically beneficial to child abuse victims: see Bruce Feldthusen, Olena Hankivsky and Lorraine Greaves "Therapeutic Consequences of Civil Actions for Damages and Compensation Claims by Victims of Sexual Abuse" (2000) 12 Can J Women \& L 66.

${ }^{5}$ A number of writers have suggested that the ombudsman is a more effective provider of remedies: Carol Harlow State Liability: Tort Law and Beyond (Oxford, Oxford University Press, 2004) at 122; Lord Hoffmann "Reforming the Law of Public Authority Negligence" (2009) The Bar Council <www.barcouncil.org.uk> at [15]. On the role of ombudsmen in general see Richard Moules Actions against Public Officials: Legitimate Expectations, Misstatement and Misconduct (Sweet \& Maxwell, London, 2009), at ch 10.

${ }^{6}$ Allen M Linden and Bruce Feldthusen Canadian Tort Law $\left(9^{\text {th }}\right.$ ed, LexisNexis, Markham, Ontario, 2011) at 22-23, citing G Hadfield "Framing the Choice Between Cash and the Courthouse" (2008) 42 Law \& Soc'y Rev 645, at 673. An earlier edition of this chapter was cited by Cooke P in Re Chase [1989] 1 NZLR 325 (CA).
} 
causation and bringing the plaintiff's suffering within a recognised head of "damage." They are not compensatory, and therefore should not be barred by the accident compensation legislation.

In New Zealand, damages for personal injury are barred by the accident compensation scheme. ${ }^{7}$ This statutory scheme provides compensation for most personal injuries, and those who have "cover" under the scheme are barred from suing in tort. The problem with this is that tort law has functions that cannot be replaced by a statutory compensation scheme, such as the way it enables child abuse victims to find out through discovery how the government failed to protect them.

In removing personal injury claims from tort law, the accident compensation scheme also removed that part of tort law which helped control the relationship between public authorities and individuals. As Carol Harlow has written, "public lawyers ... have tended to overlook the significance of the transfer." ${ }^{8}$ Gault $J$ has described how before the New Zealand Bill of Rights Act 1990 (NZBORA) was enacted, the rights in that Act were protected in the common law, including tort: ${ }^{9}$

In our system, at least in the past, it has generally been the exception for rights to be defined solely in terms of the individual person's relationship with the state. So the tort of trespass applies equally to the citizen as to the state. Many of the fundamental cases establishing the principles of tort arose from the actions of government. The great trespass case of Entick $v$ Carrington (1765) 19 State Tr 1029 concerned a warrant under the hand of the Secretary of State. That the Bill of Rights Act is limited to the actions of government and its agencies does not deny the fact that many of the rights enumerated are already protected in the general law.

In this thesis it is argued that like cases brought under NZBORA, the child welfare decisions are about public wrongs. Underpinning the cases are community duties to protect children. The New Zealand Court of Appeal in $S v$ Attorney-General imposed liability on the Crown for the abuse of foster parents partly because: ${ }^{10}$

... recognition of the special obligation of protection of children imposed on the superintendent as a surrogate of the New Zealand community, renders it fair that compensation for the innocent victim's serious and long-lasting injury should be borne by and distributed amongst the community; or else it will not be compensated at all and the community obligation will not have been recognised.

\footnotetext{
${ }^{7}$ This is discussed in more detail in chapter two.

${ }^{8}$ Carol Harlow, above n 5, at 92.

${ }^{9}$ Simpson v Attorney-General [1994] 3 NZLR 667 (CA) [Baigent's Case], at 710. Gault J was dissenting. See also his judgment in Attorney-General v Chapman [2011] NZSC 110.

${ }^{10} S$ v Attorney-General [2003] 3 NZLR 450, at [70], emphasis added.
} 
In both New Zealand and in England there are statutory duties placed on public authorities to protect children. For example it is the duty of the Chief Executive of Child Youth and Family Services in New Zealand "to take such positive and prompt action and steps" as will "promote the well-being of children, young persons, and their families and family groups". ${ }^{11}$

Vindicatory damages would be intended to mark the importance of this underlying community obligation, rather than attempting to compensate the loss caused by the breach.

\section{B Public and Private Defendants}

The child welfare cases analysed in this thesis involve both public defendants, in New Zealand usually the Crown, and private defendants such as the Catholic Social Services (although this is arguably public). ${ }^{12}$ Given the limits of this thesis, the arguments concentrate on public authority liability. There are three reasons for this.

First, much of the support for the vindicatory approach advanced in this thesis comes from the developments in the jurisprudence on damages for breaches of the New Zealand Bill of Rights Act 1990 (NZBORA). It is argued that explicitly vindicatory damages should be available in tort law in the same way these are available for breaches of NZBORA partly because similar interests underpin both actions. This is most obvious when the defendant is a public authority, although vindicatory damages may also be useful to mark wrongs between private individuals.

Secondly, where the defendant is a public authority, this raises a number of distinct issues. For example, in some of the cases, it is alleged that the defendant authority failed to investigate complaints it received that the plaintiff was suffering abuse. ${ }^{13}$ This involves an exercise of statutory power which is usually associated with public authorities. It also concerns an omission, for which the common law does not usually impose liability. There may be good reasons for this rule in relation to private defendants, but the issue is different where the defendant is a public authority. This is discussed in chapter six.

Thirdly, the state is representative of the community in a way which is not typical of private defendants. When a public authority like New Zealand's Child Youth and Family Services negligently fails to prevent child abuse, it arguably breaches not only its statutory duties, but

\footnotetext{
${ }^{11}$ Children, Young Persons, and their Family Act 1989 (NZ) ss 7 and 4 (s 7 provides that it is the duty of the Chief Executive to promote the objects of the Act, which are in s 4). See also the Children Act 1989 (UK) ss 22 and 47. The Crimes Act 1961 (NZ), s 152 includes a duty on parents and persons in the place of a parent to provide necessaries for any child in their actual custody and to take reasonable steps to protect that child from injury. See also ss 150A, 195 and 195A. The relationship between the statutory duties and liability in tort law is explored in chapter eight.

${ }^{12}$ See for example $A v$ Roman Catholic Archdiocese of Wellington [2008] NZCA 49, [2008] 3 NZLR 289.

${ }^{13}$ Attorney-General v Prince and Gardner [1998] 1 NZLR 262 (CA), D v East Berkshire Community NHS Trust [2003] EWCA Civ 1151, [2004] QB 558.
} 
the duties of the wider community to look after children. ${ }^{14}$ In England the provider of child welfare services is the local council, rather than central government, but this still has a representative function. This "public" aspect of the cases is reflected in the role of vindication: it is not just the defendant's wrongs which are being vindicated, but the failure of the community as a whole to look after its children.

However, many of the arguments in favour of a vindicatory approach apply whether the defendant is private or public. For example, it is argued that a non-compensatory award is useful where the claim would otherwise be struck out because there is no "loss" (especially in negligence), because litigation can help to reveal facts about how the wrong was caused: ${ }^{15}$

The adversarial process performs a valuable function in allowing individual victims - and the public, vicariously - an opportunity to confront large social institutions, express moral indignation, and achieve clear-cut vindication of rights.

This applies whether the defendant is the Crown or the Catholic Social Services. Some of the cases relied on as support for a vindicatory approach within tort law are also private. ${ }^{16}$ Therefore it is not argued that a vindicatory approach should be applied only where the defendant is a public authority, but merely that these cases present a good example of where such an approach is appropriate.

\section{Structure of this Thesis}

The structure of this thesis is somewhat counter-intuitive. The remedy is discussed before the liability issues (although they inevitably overlap). In the next four chapters, it is argued that the child welfare cases do not sit comfortably within the compensatory principle: the damages are better seen as vindicatory, awarded for the wrong rather than the consequences. There is a discussion whether the development of this approach in NZBORA damages can be incorporated into tort law (chapter four) and whether there is support within existing tort law for such an approach (chapter five).

The remaining chapters focus on the wrong which is being vindicated. In chapter six the developments in vicarious liability are discussed. These have allowed child abuse victims to sue the employers of their abusers in tort, and in New Zealand for child abuse victims to sue the Crown for the torts of foster parents. Although non-loss based damages may seem

\footnotetext{
${ }^{14}$ For the argument that community does have duties to look after children, see John Eekelaar "Parental responsibility: State of Nature or Nature of the State? (1991) 13 JSWFL 37, "Are Parents Morally Obligated to Care for Their Children? (1991) 11 OJLS 340.

${ }^{15}$ David Rosenberg “The Dusting of America: a Story of Asbestos - Carnage, Cover-up, and Litigation” (1968) 99 HLR 1693, at 1705. See also Scott Hershovitz "Harry Potter and the Trouble with Tort Theory" (2010) 63 Stan L Rev 67, at 72.

${ }^{16}$ For example Rees $v$ Darlington Memorial Hospital NHS Trust [2004] 1 AC 309(HL). Chapter five analyses whether there is support for a vindicatory approach within existing tort law.
} 


\section{Chapter I Introduction}

incongruous for vicarious liability because it is usually regarded as strict (non-fault), it is argued that vindicatory damages should be awarded where there is a relationship between the plaintiff and defendant.

Chapters seven and eight deal with issues which arise when the public authority is sued directly, for example for failing to prevent the abuse which the plaintiff suffered as a child. The allegation in such cases often concerns an omission (chapter seven) and the way in which a statutory power is exercised (chapter eight). An orthodox application of negligence rules might prevent liability being established in these cases, partly because it requires treating public authorities differently from private individuals (something not traditionally done in tort law). However, this recognises the special position of such authorities, which are entrusted with powers specifically designed to help prevent the wrongs which the plaintiffs are complaining about. The development of negligence law in these cases can be helpfully understood as vindicating the underlying obligations discussed in the first half of the thesis. 


\section{Vindication as an Alternative to Compensation}

In 1997, the New Zealand Court of Appeal in Prince refused to strike out a claim that the Department of Social Welfare had negligently failed to investigate a complaint they received that the plaintiff was being ill-treated by his adoptive parents. ${ }^{1}$ This decision marked the beginning of what is arguably a sui generis body of tort case law concerning child welfare. The English Court of Appeal made a similar decision in 2003 in D vast Berkshire. ${ }^{2}$

As well as claims like Prince which allege that a public authority through its own negligence failed to prevent the plaintiff from being neglected or abused, many cases have been brought alleging that the defendant's employees abused the plaintiff. ${ }^{3}$ These last cases are usually brought vicariously. In New Zealand, cases in tort against the Crown must be brought vicariously, under s 6 of the Crown Proceedings Act 1950. This means that a particular wrongdoer must be identified, making systemic negligence claims problematic. However, in practice New Zealand courts have not always strictly applied the Act, and in some cases, including some of the child protection cases, they appear to have allowed claims brought directly against the Crown. ${ }^{4}$

In both the direct negligence cases like Prince and East Berkshire and the employee abuse cases the allegations are difficult to frame in orthodox tort law terms. The traditional focus of tort law damages is predominantly compensatory: the damages are intended to put the plaintiff in the position he or she would have been but for the wrong. In this chapter an alternative approach is developed, in which damages would be intended to mark the wrong rather than to compensate the loss caused by the abuse.

\section{A Are These Cases about shifting loss?}

So far, the child welfare cases have mostly been brought as loss-based claims. This fits with a widespread ideal that tort law is primarily focused on shifting loss between parties. $^{5}$ Under this paradigm, child abuse victims bring complaints against the state

\footnotetext{
${ }^{1}$ Attorney-General v Prince and Gardner [1998] 1 NZLR 262 (CA).

${ }^{2}$ D v East Berkshire Community NHS Trust [2003] EWCA Civ 1151, [2004] QB 558.

${ }^{3} S v$ Attorney-General [2003] 3 NZLR 450 (CA) is an example of this, although in that case the Crown was held liable for the torts of foster parents, not employees. This issue is discussed in chapter six.

${ }^{4}$ Stuart Anderson "'Grave injustice': the insecure foundations of crown liability for torts in New Zealand" (2009) 12 Otago LR 1, at 20. Anderson cites Prince, above n 1, as an example of direct liability against a government department.

${ }^{5}$ Adherents of this ideal include Allan Beever Rediscovering the Law of Negligence (Hart Publishing, Oxford, 2007) and Lord Hoffmann "Reforming the Law of Public Authority Negligence" (2009) The

Bar Council <www.barcouncil.org.uk>. For an argument to the opposite effect, see Dan Priel "A Public Role for the Intentional Torts" (2011) Social Science Research Network <www.ssrn.com>.
} 
for having failed to protect them, claiming damages representing the loss that they suffered. For example, in a 2008 English case $B v$ London Borough of Ealing the judge calculated that the plaintiff's loss caused by the abuse she had suffered as a child totalled $£ 50,372$, divided into the following heads: past loss of earnings, future loss of earnings, medical expenses for therapy (including travel) and pain and suffering. ${ }^{6}$ He also awarded $£ 1,072$ for a proportion of the money spent on alcohol caused by the plaintiff's alcohol addiction which the judge held was partly caused by the abuse.

There are at least three difficulties with this loss-based approach. First, it is not clear that tort law does this very well. Such loss is often deducted anyway for benefits received through social welfare, which arguably represents a better means of compensating such harm. ${ }^{7}$

Secondly, cases like Prince and East Berkshire are brought in negligence, and it is arguable that child abuse victims have not suffered the type of "damage" necessary to establish a claim in this tort. For example Henaghan has criticised those involved in Prince for not asking whether there was the type of damage required to establish an action in negligence: ${ }^{8}$

A big gap in how this case was argued is that the Crown seems to have overlooked that for an action in negligence there must be some recognisable damage. The only specific damage that was claimed here was "impairment of personal and intellectual development" and "emotional abuse". Neither of these are currently recognisable damages for a tort action in negligence. Unwittingly, the majority of the Court of Appeal by not striking out the action have opened up the doors to new areas of claim in negligence -- areas which are wide and vague that will create a field day for social scientists debating the nature/nurture argument in Courts and trying to quantify "impairment" and "emotional abuse".

This criticism might seem odd when applied to the victims of abuse or neglect: it should be possible to develop the tort of negligence sufficiently so that child abuse, for example, can form a "recognisable damage". However, Henaghan's observation hints at a more fundamental problem with these cases. The effects of child abuse are life-long and complex. It may impair the intellectual and emotional development of the victim, as the plaintiff in Prince alleged, in ways which are impossible to disentangle from personality traits passed down in the gene pool or attributable to

\footnotetext{
${ }^{6}$ B v London Borough of Ealing [2008] EWHC 1262 (QB).

${ }^{7}$ For a critique of the way tort law deals with compensation for personal injuries generally, see Peter Cane Atiyah's Accidents, Compensation and the Law (7th ed, Cambridge University Press, Cambridge, 2006).

${ }^{8}$ Mark Henaghan "Editorial: Suing for an appalling childhood" (1997) 2 BFLJ 174, at 175.
} 
other factors in the child's environment. Should these effects of abuse be categorised as "loss" to be compensated by negligence, and how might the courts quantify this?

The third problem with these cases is that the whole claim is usually barred in New Zealand by its statutory compensation scheme. ${ }^{9}$ If the child welfare cases are only about loss, this suggests that there may be no claim at all in New Zealand, where loss caused by sexual abuse and child abuse is usually compensated under the statutory scheme, and tort claims for additional compensation are therefore barred. However, if it is recognised that the child welfare cases are not really concerned with shifting loss from one party to another but rather with the recognition of an important wrong, the argument that the accident compensation bar should not apply to this aspect of the damages award becomes more compelling.

If the child abuse cases are not about "loss" in the tort law sense, should they be brought in tort law at all? In this thesis it is argued that because tort law is not always about loss, non-loss based damages may be appropriate as a marker that an important community obligation has been breached. Lord Wilberforce made a similar observation, in the context of a discussion whether exemplary damages are appropriate in "private" tort law: ${ }^{10}$

It cannot lightly be taken for granted, even as a matter of theory, that the purpose of the law of tort is compensation, still less that it ought to be, an issue of large social import, or that there is something inappropriate or illogical or anomalous (a questionbegging word) in including a punitive element in civil damages, or, conversely, that the criminal law, rather than the civil law, is in these cases the better instrument for conveying social disapproval, or for redressing a wrong to the social fabric, or that damages in any case can be broken down into the two separate elements. As a matter of practice English law has not committed itself to any of these theories: it may have been wiser than it knew.

\section{B The Compensation Conception of Tort Law}

Despite Lord Wilberforce's words, there is a widely held assumption now that tort law is chiefly concerned with compensating loss. That assumption underpins two of the most important conceptions of tort law: the corrective and the distributive justice theories.

\footnotetext{
${ }^{9}$ Discussed below in the last main section of this chapter.

${ }^{10}$ Cassell \& Co Ltd v Broome [1972] AC 1027 (HL), at 1114; quoted with approval by Richardson J in Taylor v Beere [1982] 1 NZLR 81 (CA), at 90, Cooke P in Re Chase [1989] 1 NZLR 325 (CA), at 332, and Elias CJ (dissenting) in Couch v Attorney-General (No 2) (on appeal from Hobson v AttorneyGeneral) [2010] NZSC 27; [2010] 3 NZLR 149, at [20]. However, Tipping J in the majority in Couch (No 2) was critical of this passage, at [142].
} 
In the first theory, tort law is described as a way of protecting certain interests, such as bodily integrity or the right not to be lied to. When those rights or interests are violated by the defendant, he or she must compensate the plaintiff for the loss which that violation has caused. Beever has written that: ${ }^{11}$

... when one of the rights of the wrong-sufferer is violated, corrective justice sees this as an injustice and aims to correct the injustice ... the wrong consists in the wrongdoer interfering with the wrong-sufferer's right, the remedy in requiring the wrongdoer to undo that wrong, typically by compensating the wrong-sufferer.

An alternative conception of tort law, distributive justice, views tort law as allocating loss to those who can best pay for it or who enjoy the benefit of the risk which led to the loss. Fleming described this approach as "not simply a redirection of losses from the victim to the wrongdoer [but rather] the allocation of risks and losses according to broader utilitarian goals." 12

In both theories, the focus is on the loss suffered by the victim. This is consistent with the rule that tort law puts plaintiffs in the position they would have been in if the tort had never occurred. ${ }^{13}$ This is the foundation for the distinction often drawn between tort and contract damages, that in contract the plaintiff "is entitled to be put into the position he would have been in if the contract ... had been performed" but in tort the plaintiff is only entitled to be put in the position he or she would have been had there been no tort. ${ }^{14}$ However, the compensatory rule of tort law does not give the whole picture.

Beever's approach can be compared to that adopted by Cane, who has also analysed tort law in terms of protected interests but does not argue, as Beever does, that damages for a violation of an interest must be compensatory. The difference between the two writers is highlighted by the way they treat exemplary damages, which are not compensatory, but are intended to punish the defendant. ${ }^{15}$ Beever would abolish exemplary damages because "punishment is foreign to the structure of private law". ${ }^{16}$ This reflects his belief that tort law is solely private law, focused on the relationship

\footnotetext{
${ }^{11}$ Beever, above $\mathrm{n} 5$, at 45 .

12 John G Fleming The Law of Torts (9th ed, Sweet \& Maxwell, London, 1998) at 11; see also the discussion of Fleming's theory by Harold Luntz in "Liability of statutory authorities for omissions" (1998) 6 TLJ 107.

${ }^{13}$ Livingstone v Reywards Coal Co (1880) LR 5 App Cas 25 (HL).

${ }^{14}$ McGregor on Damages (18th ed Sweet \& Maxwell, London, 2009) at 766. An earlier wording of this passage was approved by Gault J in Cox \& Coxon Ltd v Leipst [1999] 2 NZLR 15 (CA) at pp 1920, see McGregor on Damages (16th ed Sweet \& Maxwell, London, 1997) at 810.

${ }^{15}$ Couch (No 2), above n 10. Exemplary damages are discussed in chapter five.

${ }^{16}$ Allan Beever "The Structure of Aggravated and Exemplary Damages" (2003) 23 OJLS 87, at 105.
} 
between the plaintiff and defendant, to the exclusion of the interests of the wider community, which may include seeing the defendant punished. Cane writes, however, that arguments to abolish exemplary damages are based on a fundamental mistake: ${ }^{17}$

[This] is an assumption that compensation for loss is the only function of tort law [however] tort law is not just about making good losses, but is also concerned to protect certain rights irrespective of whether interference with the right causes damage.

As this debate suggests, the difference in approach is more fundamental than whether tort law remedies are chiefly compensatory: it concerns the issue whether tort law can include public law purposes. Beever might argue that private law has no place for a non-loss based remedy such as vindicatory damages, because they do not relate to the relationship between the parties but to public law notions such as vindicating rights and duties in the sight of the community. Such a remedy has one eye to the audience: it ensures that others outside the relationship between the plaintiff and defendant realise how important the right is. In chapter three, the child welfare cases are analysed in respect of how the plaintiffs have tried to frame the "loss" which they have suffered. It is argued that their suffering does not fit easily into the traditional tort conceptions of "damage", and that the compensatory principle should not control these cases.

The problem is not simply that the loss is difficult to calculate: that is a familiar issue in tort law. There is a more fundamental problem with these cases: they are concerned with the wrong suffered, rather than the subsequent loss. Tort law, however, has usually been developed as a response to the loss caused by the wrong. An alternative non-loss based approach in which damages could be awarded to mark the wrong rather than to compensate would be controversial. However, in this thesis it is argued that the advantages of such an approach outweigh this difficulty.

\section{Vindication}

Vindication as a purpose of a damages award has begun to be explored in the last twenty years, particularly in the human rights damages context. ${ }^{18}$ It has at least two meanings, both of which can be utilised in the search for an appropriate remedy for the breach of a community obligation to protect children. The first is that vindication

\footnotetext{
${ }^{17}$ Peter Cane The Anatomy of Tort Law (Oxford University Press, Oxford, 1997) at 116.

${ }^{18}$ See Vancouver (City) v Ward 2010 SCC 27; [2010] 2 SCR 28 (Charter damages); Taunoa v AttornyGeneral [2007] NZSC 70, [2008] 1 NZLR 429 (NZBORA damages). See also Fose v Minister of Safety and Security, [1997] 3 SA 786 (CC).
} 
focuses on the wrong suffered rather than the consequences. A vindicatory remedy will be designed to remedy the wrong whether or not the plaintiff suffers loss: ${ }^{19}$

Essentially, the word 'vindication' is used to mean making good the plaintiff's rights. To do that, a person whose claim has been upheld will need to be granted an effective remedy.

A second meaning is found in the judgments on damages for breaches of human rights legislation. This is that when human rights are breached (and arguably the logic extends to important community obligations) the whole community suffers, as a secondary victim. ${ }^{20}$

\section{Damages for the wrong rather than the loss}

Vindication in the first sense implies a focus on the wrong rather than the subsequent loss. The emphasis is on the public recognition that the defendant has wronged the plaintiff, rather than any loss which the wrongdoer has caused the victim. Priel has written that vindication provides "a public and impartial ... forum for declaring that a claimant's rights ... have been infringed." 21

The difference between damages which are awarded to recognise a wrong and those which compensate a loss became important in Donselaar $v$ Donselaar, when the New Zealand Court of Appeal had to decide whether New Zealand's accident compensation scheme barred claims for exemplary damages. ${ }^{22}$ While exemplary damages are usually described as concerned with punishment rather than vindication, the case is useful for the way the judges distinguished between the wrong and its consequences, and held that the accident compensation bar applied only to damages for the latter.

Donselaar concerned a long-running feud between two brothers, one of whom had hit the other across the head with a hammer. The Accident Compensation Act 1972 barred "proceedings for damages arising directly or indirectly out of the injury or death" of the victim. ${ }^{23}$ Although the Court of Appeal held that the provocation which led to the assault made exemplary damages inappropriate, they ruled that such damages were available for personal injury in New Zealand despite the accident compensation bar, partly because of the distinction between the wrong and the

\footnotetext{
${ }^{19}$ Norman Witzleb and Robyn Carroll "The role of vindication in torts damages" (2009) 17 Tort L Rev 16, at 18. See also David Pearce and Roger Halson "Damages for Breach of Contract: Compensation, Restitution and Vindication" (2008) 28 OJLS 73.

${ }^{20}$ Taunoa v Attorney-General, above n 18, at [317] per Tipping J.

${ }^{21}$ Dan Priel, above n 5, at 20, emphasis in original.

${ }^{22}$ Donselaar v Donselaar [1982] 1 NZLR 97 (CA).

${ }^{23}$ Section 5.
} 
consequence. Richardson $\mathrm{J}$ said that "it is the quality of the defendant's conduct which is in question not whether the plaintiff has suffered a particular type of harm." 24 Cooke $\mathrm{J}$ quoted from O'Regan $\mathrm{J}$ in Howse $v$ Attorney-General, that exemplary damages could be awarded because they arose "from the acts done contrary to law and not from the harm caused to the plaintiffs by such acts." 25

Like exemplary damages, it has been held that vindicatory NZBORA damages are not necessarily barred by accident compensation because they are not loss-based. In Wilding, the New Zealand Court of Appeal decided that although NZBORA damages for personal injury were barred by the accident compensation scheme, there could be an award beyond compensation to recognise the affront to the plaintiff's rights. ${ }^{26}$ The plaintiff in Wilding alleged that police had ordered a police dog to bite him while he was lying on the ground hand cuffed. Blanchard J, writing for the Court, observed that any compensation: "would be for the affront, not for its physical consequences. Putting it another way, there could be damages for the assault, but not for the battery." 27 Damages would be "directed at compensating only for the breach of the right." 28 The remedy would focus on the wrong, not the consequences.

Damages which are awarded for the wrong rather than the consequential loss are usually thought of as vindicating the plaintiff's rights, as occurs when the concept is used in the jurisprudence on the NZBORA. A vindicatory award could also be used to mark the importance of the defendant's duty, however. There is a suggestion of this in the reasoning of the New Zealand Court of Appeal's decision in $S v$ AttorneyGeneral. The Court held that the Crown was vicariously liable when foster parents abused the foster children in its care because otherwise "the community obligation will not have been recognised." 29 The English judge Sir John Laws has written extrajudicially of the importance of duties as well as rights: ${ }^{30}$

A society whose values are defined by reference to individual rights is by that very fact already impoverished. Its culture says nothing about individual duty - nothing about virtue ... Accordingly rights must be put in their proper place.

\footnotetext{
${ }^{24}$ Ibid, at 109 , emphasis added.

${ }^{25}$ Howse v Attorney-General SC Palmerston North, A 132/75, 22 December 1977, quoted in Donselaar, above n 22, at 102, per Cooke J. Emphasis added.

${ }^{26}$ Wilding v Attorney-General [2003] 3 NZLR 787 (CA).

${ }^{27}$ Ibid, at [16].

${ }^{28}$ Ibid.

${ }^{29} S v$ Attorney-General, above n 3, at [70].

${ }^{30}$ Sir John Laws "The limitations of human rights" [1998] PL 254, at 255.
} 
Rights and duties might simply be two sides of the same coin: a plaintiff's right to physical integrity is the defendant' duty not to hit him. ${ }^{31}$ However, it may be more useful to describe the protected interest in the child welfare cases as an obligation or duty, as the Court of Appeal in $S$ did, rather than arguing that the action vindicates the child's right to protection. This shifts the focus onto the way the community failed in its obligation to take care of children, instead of children's rights, which present difficulties because of children's lack of autonomy. ${ }^{32}$ The focus on community obligation reflects a widely felt sentiment in New Zealand that child abuse is something which the government must take responsibility for, and a sense of nationwide guilt at the high statistics of child abuse in New Zealand. ${ }^{33}$

\section{The public law aspect of vindication}

Vindicatory damages cases often have a public aspect to them. This is implicit in Wilding with the focus on the breach of NZBORA rights. This public law aspect has been made more explicit in later NZBORA cases such as Taunoa and in the human rights damages jurisprudence overseas, which this thesis draws on in support of a vindicatory remedy. In Taunoa the plaintiffs were prisoners who had been put under a "behavioural modification scheme", which included unlawful solitary confinement, strip searching in prison corridors, and a lack of time and space to exercise. Tipping $\mathrm{J}$ identified vindication as a distinct purpose of NZBORA damages, which focused on the wider context beyond the dispute between the plaintiff and defendant: ${ }^{34}$

... when there is a breach of human rights there are two victims. First there is an immediate victim. The interests of that victim require the court to consider what, if any, compensation is due. But, because the breach also tends to undermine the rule of law and societal norms, society as a whole becomes a victim too. Hence, the court must also consider what is necessary by way of vindication in order to protect society's interests in the observance of fundamental rights and freedoms.

\footnotetext{
${ }^{31}$ The classic discussion of this issue is WN Hohfeld "Some Fundamental Legal Conceptions as Applied in Judicial Reasoning” (1913) 23 Yale LJ 16.

${ }^{32}$ Of course, autonomy is not the only possible reason for having rights, and several authors have offered explanations why children have rights despite a lack of autonomy, see Michael Freeman "Taking Children's Rights More Seriously" in Michael Freeman (ed) The moral status of children: Essays on the Rights of the Child (Kluwer Law International, The Hague, 1997); John Eekelaar: "The Importance of Thinking that Children Have Rights" in Philip Alston, Stephen Parker and John Seymour (eds) Children, Rights and the Law (Oxford University Press, Oxford, 1992) 221. The importance of children's rights in New Zealand is underscored by its commitment to the Convention on the Rights of the Child (opened for signature 20 November 1989, entered into force 2 September 1990).

${ }^{33}$ See The Green Paper for Vulnerable Children Every child thrives, belongs, achieves (2011) $<$ www.msd.govt.nz>.

${ }^{34}$ Taunoa, above n 18, at [317].
} 
This two victim explanation of vindication helps explain the child abuse cases. When children suffer neglect or abuse, the wider community suffers as a secondary victim and has an interest in seeing the primary victim's wrong vindicated through an award of damages.

In Ward the Supreme Court of Canada also identified vindication as a distinct purpose of Charter damages. ${ }^{35}$ The plaintiff had been detained because he was suspected of planning to throw a pie at the Prime Minister. He was strip-searched in breach of his rights under the Charter. The Supreme Court upheld the trial judge's award of $\$ 5000$ and identified three purposes of Charter damages: compensation, deterrence, and vindication. It described the latter as follows: ${ }^{36}$

Vindication focuses on the harm the infringement causes society ... violations of constitutionally protected rights harm not only their particular victims, but society as a whole. This is because they "impair public confidence and diminish public faith in the efficacy of the [constitutional] protection". While one may speak of vindication as underlining the seriousness of the harm done to the claimant, vindication as an object of constitutional damages focuses on the harm the Charter breach causes to the state and to society.

\section{D “Bothersome” Damages}

One of the reasons for developing a vindicatory remedy is to enable tort law to fulfil what Linden calls its ombudsmen role. ${ }^{37}$ Like an ombudsman, tort law can reveal how the plaintiff's wrong occurred: ${ }^{38}$

A tort suit can challenge the decision-making power of the omnipotent and omnipresent managers of modern society. In a world dominated increasingly by distant, elite decision-makers, this watchdog role is becoming more and more necessary.

Building on the analogy with the ombudsman, support for the availability of vindicatory damages in tort law is found in the development by the United Kingdom Parliamentary Commission for Administration's development of what appears to be a vindicatory remedy to mark government maladministration, which the Commission described as "bothersome damages". 39 They are awarded when government maladministration has caused exceptional distress or worry. The damages are intended to mark the wrong rather than to provide compensation: as Harlow has

\footnotetext{
${ }^{35}$ Charter, above n 18.

${ }^{36}$ Ibid, [28], citing Fose, above n 18, at [82].

${ }^{37}$ AM Linden “Tort Law as Ombudsman” (1973) 51 Can B Rev 155.

${ }^{38}$ Ibid, at 159.

${ }^{39}$ Parliamentary Commissioner for Administration, Maladministration and Redress, HC 112 (1994-5).
} 
argued they represent a "manifestation of sympathy and solace" rather than full redress. $^{40}$

The Commission's 2011 report "A Breach of Confidence" is a good example of its approach. $^{41}$ A number of government departments mistakenly changed Ms M's address in their computer system to the new address of her ex-partner, from whom she had recently separated. This led to a number of documents containing personal information about her finances being sent to his house. When she complained, none of the departments (including HM Revenue \& Customs, the Child Support Agency and the Department for Work and Pensions) accepted responsibility, instead directing her to other departments. The Commissioner found: ${ }^{42}$

Each of the agencies blamed another for the original mistake and took the view that, as the mistake had been disseminated by 'the system' it was not their responsibility and there was nothing they could do.

Ms M, said that she felt humiliated that her ex-partner knew that she was in financial difficulty. ${ }^{43}$ The Commissioner held that there was maladministration and injustice, causing Ms M anxiety and distress. She recommended that HM Revenue \& Customs pay Ms M $£ 2,000$ "in recognition of all the injustice flowing from the maladministration identified in [the] report." 44 While this took into account costs incurred by Ms M as a result of the wrong, such as taking time off work to meet with her MP ${ }^{45}$ the payment is not described in compensatory terms: it is to vindicate the wrong rather than to compensate it.

The New Zealand ombudsmen do not seem to have developed a practice of recommending "bothersome" damages. However, there is a somewhat similar head of damages available in New Zealand's Human Rights Act 1993, which protects the right not to be discriminated against. Section $92 \mathrm{M}(1)(\mathrm{c})$ provides for damages for "humiliation, loss of dignity, and injury to the feelings of the complainant."

Such damages are similar to those awarded for breach of the rights in NZBORA, and should be available in tort law. They are potentially a useful remedy through which New Zealand courts could recognise the wrong done to the plaintiff when the claim

\footnotetext{
${ }^{40}$ Carol Harlow State Liability: Tort Law and Beyond (Oxford, Oxford University Press, 2004) at 123.

${ }^{41}$ Parliamentary and Health Service Ombudsman "A Breach of Confidence: A report by the Parliamentary Ombudsman on an investigation of a complaint about HM Revenue \& Customs, the Child Support Agency and the Department for Work and Pensions" (2011)

$<$ www.ombudsman.org.uk>.

42 Ibid, at [84].

43 Ibid, at [98].

${ }^{44}$ Ibid, at [109] emphasis added.

${ }^{45}$ The Parliamentary ombudsman in the UK can only receive complaints from MPs.
} 
would otherwise be barred in New Zealand because of the accident compensation scheme. Vindicatory damages would enable tort law to fulfil its ombudsman role.

\section{E Can Vindication be Achieved through Litigation?}

While accepting that Parliamentary ombudsmen might mark wrongs through "bothersome" damages, some might argue that litigation is an inappropriate way of achieving vindication. In a 2011 child abuse case against the Legal Services Agency, Dobson $\mathrm{J}$ requested that such complaints be dealt with outside the judicial process: ${ }^{46}$

The judgments in many of the decided cases have included observations about the inappropriateness of these historic abuse claims being addressed in conventional litigation form ...To the extent that many of these claimants place a priority on vindication of their complaints rather than financial success, then pursuit of litigation is likely to expose them to substantial on-going stress, in many cases the high prospects of failure and, for those who proceed to trial, the additional stress of having the accounts of their tragic pasts tested in what cannot be other than an unsympathetic forum. In many situations, vindication is achieved by an acknowledgement of wrongdoing by those with responsibility for having caused the wrong in the first place. That is not an outcome that is achievable in litigation.

However, while executive-controlled non-adversarial proceedings may be more suitable for child abuse claims, the judiciary should not abdicate its responsibility in providing a forum for vindicating rights against the Crown. Where the rights are claimed against the state, it is constitutionally troubling to argue that plaintiffs should be discouraged from bringing their complaints to court, even where a better outcome might be obtained in a process controlled by the executive. ${ }^{47}$ The complaint is that the executive harmed the plaintiff (or failed to prevent the plaintiff from being harmed): it is therefore important to provide the opportunity of a forum which is not controlled by the executive, even if it is expected that most claims are dealt with in an alternative process. It is not the claim of this thesis to demonstrate that litigation is the best place for child welfare claims. Rather, the thesis attempts to show how a claim to vindicate community obligations to protect children might work. This has an importance beyond cases about children, concerning non-loss based remedies more generally.

\footnotetext{
${ }^{46} J M M v$ Legal Services Agency HC Wellington CIV-2010-485-1306, CIV-2010-485-1375, CIV-2010485-1630, CIV-2010-485-1740, CIV-2010-485-1961, CIV-2010-485-2527, CIV-2010-485-1559, 14 April 2011, at [301-307].

${ }^{47}$ Cooper Legal, counsel for the plaintiff in many of the historic child abuse claims in New Zealand, makes a similar point on its website: Cooper Legal " $2^{\text {nd }}$ Quarter 2011" (2011)

$<$ www.sonjacooperlaw.co.nz>.
} 
In New Zealand the Ministry of Social Development provides an alternative to litigation for abuse victims through the Care, Claims and Resolution Team. This involves meetings with Social Work Advisors employed by the Ministry, and may result in answers to questions such as why the claimant was taken into care, a formal apology for a failure in care from the Ministry, and a possibility of financial redress. While this might meet Dobson J's demand for a government-controlled process leading to "an acknowledgement of wrong-doing by those with responsibility for having caused the wrong" there remains an important role for the courts in forcing acknowledgments of wrong-doing through "vindicatory" awards of damages.

\section{F The Limits of Vindicatory Damages}

The possibility of vindicatory damages in tort law should not be seen as a gratuitous top-up for occasions when the plaintiff feels compensatory damages are inadequate, or as a convenient award for when the plaintiff has suffered no loss. They should only be awarded where there is an important underlying right or duty which needs to be protected, and where the normal measure of damages is inappropriate or inadequate. This is consistent with the approach to NZBORA damages, as outlined by Tipping $\mathrm{J}$ in Taunoa: ${ }^{48}$

... whether more than a declaration is required to vindicate the breach is to be assessed primarily on the basis of [the following] factors: (1) the nature of the right which has been breached; and (2) the circumstances and seriousness of the breach ... (3) the seriousness of the consequences of the breach; (4) the response of the defendant to the breach; and (5) any relief awarded on a related cause of action..

In the child welfare cases the underlying duty is the obligation to protect children. The duties are found in statutes which provide public authorities with special powers to comply with them. For example it is the duty of the Chief Executive of Child Youth and Family Services in New Zealand "to take such positive and prompt action and steps" as will "promote the well-being of children, young persons, and their families and family groups". ${ }^{49}$ The duties reflect the obligations of the community, whom the public authorities represent. ${ }^{50}$ When the consequence is neglect or child abuse the seriousness is obvious. The normal tort measure of damages in these cases is inappropriate because the loss is impossible to quantify and largely dealt with by social welfare, even in countries that lack New Zealand's statutory compensation

\footnotetext{
${ }^{48}$ Taunoa, above n 18, at [305].

${ }^{49}$ Children, Young Persons, and their Family Act 1989 (NZ) ss 7 and 4 (s 7 provides that it is the duty of the Chief Executive to promote the objects of the Act, which are in s 4). See also the Children Act 1989 (UK) ss 22 and 47. The Crimes Act 1961 (NZ), s 152 includes a duty on parents and persons in the place of a parent to provide necessaries for any child in their actual custody and to take reasonable steps to protect that child from injury. See also ss 150A, 195 and 195A.

${ }^{50} S v$ Attorney-General, above n 3, at [70].
} 
scheme. However the importance of the underlying duty and the consequences of the breach make vindicatory damages to mark the wrong appropriate.

Vindicatory damages will often be unnecessary. In most tort actions, for example, compensatory damages, or other remedies such as injunctions, will be sufficient to vindicate the right. Sometimes an action for damages in NZBORA will be available if the defendant is part of the Crown. ${ }^{51}$ However, plaintiffs in the child welfare cases may struggle to find a right in NZBORA to peg their claim to. Unlike the Human Rights Act 1998 (UK), NZBORA lacks a right to family life and, unlike the Canadian Charter of Rights and Freedoms (1982), the right not to be deprived of life in s 8 is negative. This makes it difficult to infer a more positive right that the plaintiff's health must be protected, as developed in other jurisdictions. ${ }^{52}$ One of the important roles of vindicatory damages in tort law is that they allow judges to use tort actions to protect rights which are not part of NZBORA.

In chapter five other tort cases are discussed in which the award might be described as vindicating a particular right or duty. For example, in the wrongful birth case Rees the plaintiff's sterilisation was negligent and she conceived a child. ${ }^{53}$ The House of Lords awarded a "conventional award" of $£ 15,000$ to recognise the breach of the plaintiff's right to choose whether or not to have children. In Chesterv Afshar the House of Lords adapted the causation test in order to vindicate the plaintiff's right to consent to medical treatment, when her doctor had negligently failed to warn her of a small risk of surgery which eventuated. ${ }^{54}$

The right to decide whether or not to have children and the right to consent to medical treatment are good examples of interests which the law should vindicate though damages. Others, not discussed in this thesis, include the duty to look after elderly persons. By analogy with the child welfare cases analysed in this thesis, it could well be argued that when a residential care facility abuses its elderly residents, vindicatory damages should be awarded. Like children, elderly people are vulnerable, and their "damage" may be especially difficult to quantify. For example, it might be hard to argue that their career prospects have been damaged by the abuse suffered (an argument common in the child welfare cases, as discussed in chapter three).

The precise parameters of vindicatory damages would need to be worked out as where new cases come before the courts. However, the child welfare cases are a

\footnotetext{
${ }^{51}$ New Zealand Bill of Rights Act 1990, s 3. See Attorney-General v Chapman [2011] NZSC 110.

${ }^{52}$ See Andrew Butler and Petra Butler The New Zealand Bill of Rights Act: a commentary (LexisNexis, Wellington, 2005) at ch 9.

${ }^{53}$ Rees v Darlington Memorial Hospital NHS Trust [2004] 1 AC 309, [2004] 1 AC 309.

${ }^{54}$ Chester v Afshar [2004] UKHL 41, [2005] 1 AC 134: the House of Lords choose to do this through compensation rather than separate vindicatory damages, this issue is discussed in chapter five.
} 
paradigmatic example where they would be appropriate. The underlying duty to look after children is important, the loss is unsuitable for an application of the orthodox compensatory doctrines (this is explored more in chapter three) and the consequences of the breach are serious. In addition, there may sometimes be useful information to be gained about how the abuse occurred (or how the government failed to prevent it) which might be obtained through litigation.

\section{G The Accident Compensation Bar}

Vindicatory damages would be of little use in New Zealand if they were barred under the accident compensation scheme; it is argued in this section that the bar should not apply to these damages.

The accident compensation bar is unique to New Zealand: it prevents plaintiffs from bringing proceedings for personal injuries that are covered by the accident compensation scheme. ${ }^{55}$ This scheme, which came into force in 1974 , created a statutory compensation regime which provides compensatory payments for personal injuries caused by accidents. "Accident" has been broadly defined so that it includes intentional wrongs such as physical abuse. ${ }^{56}$

Court proceedings for damages for personal injuries covered by the scheme are barred ${ }^{57}$ with the important exception of exemplary damages. ${ }^{58}$ Since 1992, psychiatric injuries which are not the consequence of a physical injury have not been covered unless the psychiatric illness is caused by certain specified criminal acts. ${ }^{59}$ These include, significantly for child abuse cases, sexual abuse, and assault on a child, even where there is no criminal charge or conviction. ${ }^{60}$

For historical abuse occurring before the scheme came into force, there are complex transitional provisions which may bring the victims into the scheme. If the abuse happened before 1974 but the victim received treatment for the consequential mental injury after 1 July 1999 then cover is available and the action is statute-barred. ${ }^{61}$

\footnotetext{
${ }^{55}$ There have been a number of amendments and from time to time the whole statute has been replaced. The current Act is the Accident Compensation Act 2001. Harlow compares it to a number of less comprehensive schemes in the United Kingdom in Harlow, above n 40, at ch 3.

${ }^{56}$ Accident Compensation Act 2001 s 20; G v Auckland Hospital Board [1976] 1 NZLR 638 (SC).

${ }^{57}$ Accident Compensation Act 2001, s 317.

${ }^{58}$ Accident Compensation Act 2001, s 319; Couch v Attorney-General (No 2) [2010] NZSC 27; [2010] 3 NZLR 149.

${ }^{59}$ Accident Compensation Act 2001, s 21.

${ }^{60}$ Accident Compensation Act 2001, s 21(5) and Schedule 3.

${ }^{61}$ These provisions and the legislative history is helpfully explained by Frater $\mathrm{J}$ in the High Court decision in A Catholic Social Services [2007] 1 NZLR 536 (HC), at [500] ff, especially at [515].
} 
Compensatory damages for breach of a right in NZBORA are barred by the accident compensation scheme, but where it is necessary to vindicate the right by additional damages, these non-compensatory damages are not barred. ${ }^{62}$ This raises the question whether similarly vindicatory tort awards should also be barred. Since the courts have been prepared to split the vindicatory aspect of NZBORA damages from the compensatory element, it should be possible to do the same in tort. So far, however, the tendency has been to view all actions involving personal injury as barred, even those such as battery which it is less controversial to describe as vindicatory.

Like exemplary and NZBORA damages, vindicatory damages in tort law should not be caught by the accident compensation scheme. While accident compensation is focused on compensating the victim's loss, vindicatory damages are noncompensatory and are intended to mark a wrong. As with exemplary ${ }^{63}$ and the vindicatory aspect of NZBORA damages, a vindicatory remedy wold not be intended to compensate loss, which is achieved through the accident compensation scheme. Vindicatory damages in tort law would be intended to serve similar purposes to the public law orientated NZBORA and English ombudsman damages.

The fact that vindicatory damages arise from the wrong, not the consequential loss, is arguably consistent with the way the accident compensation bar was applied in Sivasubramaniam $v$ Yarrall. ${ }^{64}$ In this case Heath $\mathrm{J}$ held that it is possible to apportion the damages for mental injury caused by the physical injury and those caused by the accident itself. While the distinction between the different injuries might seem arbitrary, the emphasis on the difference between the accident and the personal injury caused by the accident is useful. The plaintiff was a passenger in a car accident in which her mother had also died. She suffered physical injuries, and Heath J struck out the pleadings in relation to the plaintiff's own injuries. However, he refused to strike out any trauma caused by the accident which could be separated from the mental injury caused by the physical injuries. The mental injury suffered as a secondary victim from watching her mother die was also severable.

Heath $\mathbf{J}$ acknowledged that apportioning mental injury caused by the accident and mental injury caused by the physical injury arising from the accident was difficult. However, he concluded that dual causes were common in many areas of the law and that the courts could not avoid this problem. It was consistent with the Court of Appeal decision Brownlie, in which the plaintiffs had been negligently diagnosed that they did not have cancer. They found out that they may have been misdiagnosed,

\footnotetext{
${ }^{62}$ Wilding, above $\mathrm{n} 26$.

${ }^{63}$ Donselaar, above n 22, at 109.

${ }^{64}$ Sivasubramaniam v Yarrall [2005] 3 NZLR 268 (HC). This case was applied in Comerford-Parker $v$ Accident Compensation Corporation [2011] NZAR 481 (HC).
} 
which was confirmed by subsequent testing. The Court held that any mental injury suffered in between finding out about the negligent diagnoses and the subsequent confirmation was not barred by the accident compensation scheme.

The distinction between compensatory damages for physical injury caused by the wrong and compensatory damages for other consequences of the wrong is open to criticism. It can lead to arbitrary distinctions between, for example, the trauma the plaintiffs in Brownlie suffered on finding out that they may have been negligently misdiagnosed, and the trauma suffered when they found out that they did have cancer. However, the distinction between damages arising from the wrong itself and damages arising from the consequences of the wrong is a useful one. The difficulty with Brownlie and Yarrall is that a line is drawn between different consequences which all stem from the same wrong. Vindicatory damages arise from the wrong itself, not the consequences, and should therefore not be barred by the accident compensation scheme, which focuses on the subsequent loss.

The distinction between damages for consequence, which are barred, and damages for the wrong itself, is supported by the legislative changes since the accident compensation scheme was first enacted in 1972. In the original legislation, proceedings were barred for "damages arising ... out of the injury or death" for which the victim had cover under the Act. ${ }^{65}$ This meant that all proceedings were barred, whether for the wrong (the "accident") or the resulting loss. However, in 1992 the scheme was restricted. Cover for mental injuries not caused by a physical injury was excluded from the scheme (with the exception of psychiatric illness caused by certain criminal acts) and the statutory bar was changed: ${ }^{66}$

No proceedings for damages arising directly or indirectly out of personal injury covered by this Act ... that is suffered by any person shall be brought in any Court in New Zealand independently of this Act, whether by that person or any other person, and whether under any rule of law or any enactment.

Therefore the bar now applies to the harm caused by the personal injury, not the accident itself. Vindicatory damages should therefore not be barred by accident compensation because they arise from the accident, not the personal injury, applying the reasoning in Yarrall. This accords with the different purposes of the accident compensation scheme and vindicatory damages. The latter are intended to mark wrongs, not to compensate loss. They enable tort law to fulfil its ombudsman role, and are analogous to NZBORA damages which are also not barred. Accident

\footnotetext{
${ }^{65}$ Accident Compensation Act 1972, s 5(1). Emphasis added.

${ }^{66}$ Accident Rehabilitation and Compensation Insurance Act 1992, s 14. This is substantially the same as the current s 317 in the Accident Compensation Act 2001.
} 
compensation, however, is squarely focused on compensation, and does not have a vindicatory role like tort law.

\section{H Summary}

Tort law has an important role as an ombudsman, revealing the facts which led to the plaintiff's wrong through discovery, and marking the wrong through damages. One way in which this role can be effected is through vindicatory damages, a separate, non-loss based award to mark wrongs rather than to compensate them.

The wrong in the child welfare cases often reflects a public law aspect of tort law. The cases often concern government action, and damages would vindicate the underlying duty to protect children in the same way NZBORA damages mark the breach of the underlying NZBORA right. The public law aspect of the damages award addresses the interest of the public in having the wrong vindicated.

Vindicatory damages do not fit with the most common role of tort damages, which is compensatory. However, tort law has purposes beyond compensation, and vindicatory damages enable it to achieve some of these non-compensatory purposes. Since accident compensation is restricted to remedying loss, the scheme should not bar vindicatory damages in tort law, in the same way that similar awards under NZBORA and in cases like Yarrall are not barred. 


\section{Overview of the Cases}

This chapter outlines the development of the child welfare cases in New Zealand, England and Canada in light of the vindicatory approach outlined in chapter two. It is argued that the cases are ill-suited to the compensatory principle which has ruled them so far.

There are, broadly, two types of cases analysed in this thesis. In some, it is alleged that the public authority failed through its own negligence to protect the plaintiff from abuse. This chapter includes an analysis of the leading cases in which the courts in New Zealand and England have recognised a duty of care in negligence to protect children. The other main type of case discussed in this thesis concerns children who have been abused by the employees of public authorities, for example where the authority runs a child care facility. The development of vicarious liability to fit these cases is analysed in chapter six, and the leading cases in this area do not feature in this chapter. ${ }^{1}$ However, some of the cases discussed below, particularly the Canadian decisions, fall into this vicarious liability category. They are discussed because they raise issues to do with the way the loss is analysed by the judges.

\section{A Overview of New Zealand Cases}

The child abuse cases in New Zealand fall naturally into three groups. First, Prince ${ }^{2}$ and $B v$ Attorney-General, ${ }^{3}$ both strike out actions, established a duty of care to protect children at risk of harm where the relevant government department had received a complaint concerning the child. Secondly, a group of cases were litigated at trial between 2005 and 2010. These cases all failed, for a number of reasons but chiefly because of limitation period problems. Finally, New Zealand's Legal Services Agency has refused legal aid in response to these unsuccessful cases, in decisions which have been largely upheld in appeal to the Review Panel and the High Court.

\section{The duty of care}

In Prince, the New Zealand Court of Appeal refused to strike out a claim that the Department of Social Welfare had negligently failed to investigate a complaint they received that the plaintiff was not being looked after properly by his adoptive parents. ${ }^{4}$ At the time the case was brought the Department of Social Welfare was responsible for the provision of child welfare; responsibility is now with Child Youth

\footnotetext{
${ }^{1}$ Including $S$ v Attorney-General [2003] 3 NZLR 450 (CA).

${ }^{2}$ Attorney-General v Prince and Gardner [1998] 1 NZLR 262 (CA).

${ }^{3}$ B v Attorney-General [2004] 3 NZLR 145 (PC).

${ }^{4}$ Prince, above n 2.
} 
and Family Services, which is part of the Ministry of Social Development. The focus of the Court's decision in Prince was on whether there could be a duty of care. There was no pre-existing relationship between the plaintiff and defendant, as there usually is in the arguably more classic child abuse cases analysed elsewhere in this thesis, where the plaintiff sues a child care facility in which he or she was abused.

In $B v$ Attorney-General, two girls were removed from their widower father when accusations were made that he was abusing them. ${ }^{5}$ This was in some ways the opposite of a child abuse case: the complaint was that the defendant had negligently failed to return the children to their father when there was no danger of abuse. Both the children and the father sued, alleging that the defendant owed them a duty in the way the investigation was conducted after the children were removed. The Court of Appeal held that the Prince duty only extended to the decision whether or not to investigate, not the way in which the investigation was conducted. ${ }^{6}$ The Privy Council disagreed with the Court on this point, although it upheld the Court's decision that no duty could be owed to the father because it would create a conflict of duties not to harm the father's and the children's best interests. ${ }^{7}$

In both Prince and $B v$ Attorney-General the focus was on the duty of care, and the problems of establishing a remedy are only hinted at. In Prince the majority conceded that causation would raise "obvious difficulties" at trial, ${ }^{8}$ while Henry $\mathrm{J}$ in the minority would have struck out the alleged duty of care because, among other reasons, "the problems of linking the damage claimed to any breach of duty must be substantial, if not in many cases overwhelming". " Apart from causation, it may have been difficult to establish the necessary kind of injury in negligence. It is difficult not to sympathise with the children in $B$, who through the alleged negligence of the defendant were delayed from being reunited with their father. The threshold for nonphysical personal injuries is high, however: the children may have needed to establish at trial that they had suffered a recognised psychiatric injury, as opposed to "mere distress". 10

\footnotetext{
${ }^{5}$ B v Attorney-General, above n 3.

${ }^{6}$ B v Attorney-General [1999] 2 NZLR 296 (CA). For a discussion of the Court of Appeal decision see Bill Atkin and Geoff McLay "Suing Child Welfare Agencies: A Comparative View from New Zealand"in John Dewar and Stephen Parker (eds) Family Law: processes practices pressures (Hart Publishing, Oxford, 2003) 161.

${ }^{7}$ B v Attorney-General, above n 3. For a discussion of the duty owed to the parents, see Hanna Wilberg, arguing that parents should not be owed a duty of care, "Defensive practice or conflict of duties? Policy concerns in public authority negligence claims” (2010] 126 LQR 420.

${ }^{8}$ Prince, above at 2, at 285.

${ }^{9}$ Ibid, at 280.

${ }^{10}$ White and Others $v$ Chief Constable of South Yorkshire [1992] 2 AC 455 (HL) p 491, Mustaphav Culligan of Canada Ltd 2008 SCC 27, [2008] 2 SCR 114. In New Zealand the recognised psychiatric injury test applies to secondary victims, see van Soest v Residual Health Management Unit [2000] 1
} 


\section{The cases at trial}

Prince and $B v$ Attorney-General were both strike out actions: the Courts did not need to deal with potential problems concerning damages. Between 2005 and 2010, four cases raising similar issues reached trial in the High Court of New Zealand, two of which continued on to the Court of Appeal.

In 2006 Frater $\mathrm{J}$ delivered the High Court decision in $A$, in which the plaintiff sued the Catholic Social Services for the way she had been treated during her years at St Joseph's Orphanage and School, and then later at St Mary's College as a border. ${ }^{11}$ Some of the pleadings failed because of accident compensation issues. However, the plaintiff was unable to establish the alleged facts, except for some abuse perpetrated by foster parents for whom Catholic Social Services was not vicariously liable, and the use of force by the teachers, which fell within the standards of corporal punishment which were accepted at the time. Both Frater $\mathrm{J}$ at first instance and William Young P who delivered the judgment of the Court of Appeal observed that the plaintiff's complaint concerned the quality of parenting which the orphanage and boarding school had offered. However, all the judges held that the defendants owed no duty "to maximise (or enhance) the emotional well-being" of the children within their care. ${ }^{12}$ The vindicatory approach in this thesis should not change the result in this case. Although what is arguably a private defendant like the Catholic Social Services has an important duty to protect those children in its care which could be appropriately vindicated through tort damages, that duty was not breached in $A$.

In the White case, the two plaintiffs were brothers, part of a large family whose father was abusive. ${ }^{13}$ Among other things he beat the children for getting caught when stealing on his instructions. The Department of Social Welfare knew about the family and monitored them, eventually obtaining court-ordered supervision over the boys. The Crown accepted that the Child Welfare Branch was under a duty of care. In the High Court Miller J held that this "duty to inquire" was breached during a three year period when the social worker in charge of the boys' file failed to speak alone to them, several years later when staff at the institution where the boys were placed encouraged bullying and also when the staff held one of the boys, Paul, in secure detention for three days on his arrival.

NZLR 179 (CA), but possibly not to primary victims, see $J v$ Crown Health Financing Agency HC Wellington CIV-2000-485-876, 8 February 2008, discussed below at text to footnote 30 .

${ }^{11}$ A v Roman Catholic Archdiocese of Wellington [2007] 1 NZLR 536 (HC).

${ }^{12}$ A v Roman Catholic Archdiocese of Wellington [2008] NZCA 49, [2008] 3 NZLR 289, at [118], see also the High Court decision, ibid, at [550].

${ }^{13}$ White v Attorney-General HC Wellington CIV-1999-485-85, CIV-2001-485-864, 28 November 2008; White v Attorney-General [2010] NZCA 139. Leave to appeal was refused by the Supreme Court: Wv Attorney-General [2010] NZSC 69, (2010) 19 PRNZ 921. 
Since the children were left in the care of their parents by the Child Welfare Branch while under supervision, the plaintiffs also pleaded vicarious liability for the intentional torts of their biological parents. However, Miller $\mathrm{J}$ refused to extend vicarious liability that far, although the defendants unsurprisingly accepted vicarious liability for the torts of its employees at the residential institutions, where one of the boys was sexually assaulted.

All the claims were subject however to a limitation defence, which the judge upheld. The limitation problems are beyond the scope of this thesis, (which is focused on damages issues) but they have been a significant feature of the child abuse cases. For cases after 2011, they are dealt with under the Limitation Act 2010, but for earlier cases the Limitation Act 1950 still applies. There are two main exceptions to the limitation period: where there is a relevant disability, and where the injury was not "reasonably discoverable".

The reasonable discoverability doctrine was first applied to building cases, in which latent damages to buildings had not been discovered until years afterwards. The doctrine was based on the provision of the 1950 Act that limitation periods began when the cause of action "accrued", together with the rule that damage is the "gist" of the action in negligence. ${ }^{14}$ Therefore until damage was reasonably discoverable, it could not be said that a cause of action in negligence had accrued, because there had not been any damage yet. This doctrine was extended to victims of sexual abuse, ${ }^{15}$ but not to victims of other, non-sexual abuse. ${ }^{16}$ While this doctrine may be open to a number of criticisms ${ }^{17}$ that is not the purpose of this thesis. Instead, the focus is on some of the other problems which plaintiffs may come up against in these cases, which have often been overshadowed by the limitation defence.

For some of the claims in White, such as the sexual abuse, the accident compensation bar also prevented the action. Counsel tried to avoid this bar in three ways, none of which succeeded: by arguing that detaining Paul was false imprisonment, that the abuse was a gradual process disease (which is not barred by accident compensation), and that there was no mental illness as required by the Accident Compensation Act. Miller $\mathbf{J}$ observed of this last defence that if there was no mental illness, there was also no action in negligence: ${ }^{18}$

\footnotetext{
${ }^{14}$ Sidaway v Board of Governors of the Bedlam Royal Hospital [1985] AC 871 (HL).

${ }^{15}$ Tv $H$ [1995] 3 NZLR 37 (CA).

${ }^{16}$ White (HC), above n 13, at [408]; White (CA), above n 13, at [102].

${ }^{17}$ See for example Thomas J's observations in Wv Attorney-General [1999] 2 NZLR 709(CA) at [60] ff.

${ }^{18}$ White (HC), above n 13, at [448].
} 
... the claims for damages require that the plaintiffs prove both that they suffered injury at the relevant times and that it caused the mental injuries that they complain of. In other words, this point does not take Ms Cooper any further, since the affirmative defence presumes that the plaintiffs have otherwise made out their case.

This argument underlines an important aspect of child abuse cases in New Zealand: if child abuse victims are able to establish the type of personal injury which is actionable in negligence, it will usually be barred by accident compensation. This makes vindicatory damages, which would not be barred, crucial, because they enable tort law to fulfil its role in vindicating plaintiffs against the government despite the accident compensation bar.

The defendants in White also argued that there was no causation: ${ }^{19}$

... that the plaintiffs cannot show that their unhappy lives are attributable to anything the Superintendent or his agents did. [Instead, they were] attributable to genetic predisposition or early parental neglect or abandonment.

This point was not addressed by the Miller J, although he observed of one of the plaintiffs, Earl, that he "impressed as a likeable young man whose appalling past had hampered his ability to achieve his potential." ${ }^{20}$ This causation problem has become important in other jurisdictions in which these cases have been able to get over the limitation hurdle. However, whether or not the Crown believed that the plaintiff's unhappy lives were attributable to the actions of its employees, it must have felt some responsibility, as it made ex gratia payments to both plaintiffs as well as contributions to the legal aid costs. ${ }^{21}$ Subject to the limitation rules, these payments may well be legally justified on the basis of the vindicatory approach advanced in this thesis.

In Knight the plaintiff alleged that he had been abused by the nurses at a state psychiatric hospital. ${ }^{22}$ The alleged abuse occurred when he was an adult, although the plaintiff had suffered earlier abuse as a child at Marylands School, for which the Order of St John of God who ran the school made a payment of $\$ 65,000$ voluntarily in 2003, together with an apology. The action against the Crown ${ }^{23}$ failed on the facts,

\footnotetext{
${ }^{19}$ Ibid, at [30].

${ }^{20}$ Ibid, at [34].

${ }^{21}$ Email from Sonja Cooper, counsel for the plaintiff in White, to David Neild regarding the ex gratia payments in White (19 September 2011).

${ }^{22}$ Knight v Crown Health Financing Agency HC Wellington CIV-2005-485-2678, 16 November 2007.

${ }^{23}$ The Crown Health Financing Agency is now responsible for the institution where the plaintiff claimed he had been abused.
} 
although Gendall $\mathrm{J}$ also held obiter that the positive defences based on the Limitation Act and the accident compensation bar would succeed. The loss alleged was: ${ }^{24}$

... post-traumatic stress disorder with significant behavioural and psychological dysfunction, and personality disturbance. This is characterised by a history of sexual and other offending; alcohol abuse; and inability to relate to others and to live alone; and a dependence on welfare agencies ...

Alcohol abuse and difficulty in relating to others is sadly part of a familiar pattern in abuse cases. As discussed below, this had led to difficulties in Canada in establishing causation.

In 2009 Gendall $\mathrm{J}$ delivered another decision, $J$, in which the plaintiff alleged that she had been abused during a six year period beginning when she was 18 , when she was admitted into Poirua psychiatric hospital. ${ }^{25}$ Gendall $\mathrm{J}$ found for the defendant for two reasons: the plaintiff was unable to establish most of the alleged facts, and the limitation defence succeeded. However, there was a further problem which is of interest in this thesis: Gendall $\mathrm{J}$ found that the plaintiff had suffered some "unjustified use of force" in breach of the defendant's duty of care, but that there was no recognised psychiatric injury such as post-traumatic stress disorder. ${ }^{26}$ This was problematic because, as discussed by Henaghan in relation to Prince, in negligence there must be damage before liability can be imposed, and the damage must fit within one of the recognised heads of damage. ${ }^{27}$ As Gendall J observed, there are limits on the type of damage recognised when the injury is mental illness: ${ }^{28}$

It is generally recognised that there is a need to show some recognisable psychiatric injury before the necessary elements involved in the cause of action for negligence exist. Grief, distress or being upset, do not give rise to any cause of action.

However, Gendall $\mathrm{J}$ decided that despite the lack of a recognised psychiatric injury, he could and would have awarded damages for breach of the duty of care if the Limitation Act had not applied: ${ }^{29}$

I accept that if the plaintiff's time (whilst subject to detention) was made more painful or stressful than it should have been, by reason of an actionable breach of duty on the part of the defendant, then some remedy ought to be available. To use historical terms, it would be for "pain, suffering and loss of enjoyment of life"

\footnotetext{
${ }^{24}$ Knight, above n 24, [26]

${ }^{25} \mathrm{~J} v$ Crown Health Financing Agency, above n 10.

${ }^{26} \mathrm{Ibid}$, at [501], [520] and [537].

${ }^{27}$ Henaghan, Mark "Editorial: Suing for an appalling childhood" (1997) 2 BFLJ 174.

${ }^{28} \mathrm{Jv}$ Crown Health Financing Agency, above n 10, at [534].

${ }^{29}$ Ibid, at [538], emphasis in original.
} 
experienced then. In negligence, it would have been reasonably foreseeable that a patient witnessing an assault upon another patient, would suffer distress.

The difficulty with this approach is that it is inconsistent with a line of case law which establishes that "distress" is not actionable without an injury to peg it to. ${ }^{30}$ Such an award could be based on the approach in this thesis, however, that damages could be awarded for the wrong instead of attempting to compensate the loss.

\section{Legal Services Agency litigation}

In reaction to the failure of the cases at trial, the Legal Services Agency, which had funded all of the claims, withdrew aid in most cases. This produced a third band of High Court cases, $W, L A E$ and $J M M$, in which plaintiffs appealed the decisions of the Agency to withdraw aid. ${ }^{31}$ While the judges were critical of the unreasoned decisions of the Agency, the plaintiffs met with mixed success. The main problem continued to be related to the limitation period, but there were important dicta about causation which highlighted the difficulty the compensatory principle creates in these cases. $J M M$ is a good example of this.

In $J M M$ seven appeals were brought together in the High Court, against the Review Panel's decisions supporting the Agency's withdrawal or denial of aid from the plaintiffs. Dobson J considered whether the Agency had given adequate reasons in support of its decision that a reasonable self-funded litigant would not continue the proceedings chiefly because of difficulties in establishing one of the exceptions to the limitation period. ${ }^{32}$ Although he allowed some of the appeals, the tone of his judgment does not augur well for the future success of the plaintiffs. His main criticism of the defendants related to the lack of detail in the reasons they gave in support of their decisions, although he conceded that "all those responsible for progressing this potentially overwhelming volume of historic abuse claims ... have indeed been overwhelmed by the sheer scale of their task.",33

While the focus of the decision was on the psychiatric evidence relating to the limitation problem and how this had (or had not) influenced the Agency's decision to withdraw aid, there are hints of an important causation problem that is likely to hinder

\footnotetext{
${ }^{30}$ See the cases cited in footnote 10 .

${ }^{31}$ Legal Services Agency v W HC Wellington CIV-2009-485-2191, CIV-2010-404-78, 21 April 2010; Legal Services Agency v LAE HC Wellington CIV-2009-404-3399,CIV-2009-404-3400, CIV-2009404-3401, 6 August 2009; JMMv Legal Services Agency HC Wellington CIV-2010-485-1306, CIV2010-485-1375, CIV-2010-485-1630, CIV-2010-485-1740, CIV-2010-485-1961, CIV-2010-485-2527, CIV-2010-485-1559, 14 April 2011.

${ }^{32}$ The reasonable self-funded litigant test that was applied is taken from Timmins $v$ Legal Aid Review Panel [2004] 1 NZLR 708 (HC). See $J M M$, ibid, at [15].

${ }^{33} J M M$, above n 31 , at [8].
} 
any action even if the plaintiff reaches trial. In the first appeal considered by the judge, the plaintiff $J M M$ alleged that: ${ }^{34}$

The adverse effects of physical and psychological abuse were cited as her addiction to drugs, having spent time living on the streets, working as a prostitute and having difficulty trusting people and organisations. She was also described as having low self-esteem and claustrophobia. The Agency argued that there had been no diagnosis of any illness at all.

The last sentence is significant. It suggests that there was no injury at all which would satisfy a negligence claim. Even if there had been, there were, as the Agency pointed out, "substantial difficulties in linking for causation purposes the subsequent harm complained of to the earlier abuse of which she complained." 35 This was in part because prior to leaving the family home, her alcoholic father had abused her, and the courts would need to decide whether the prior abuse had caused the "loss" (if there was any), and perhaps would need to apportion it.

Most of the other appeals also raised causation problems, although they were not fully discussed, as the focus was on how the limitation problem affected the prospects of success for the purpose of deciding whether to offer legal aid. The plaintiff GLS had obtained an expert opinion by a psychiatrist which "at its highest ... had suggested that there had been 'some causality' between DSW abuse and his 'adult personality functioning and current difficulties." ",36

For the plaintiff MSB the Agency's decision included an analysis of the causation problems, concluding that "the issue of causation would be too difficult to overcome, even if a 'contribution' test was applied. Accordingly, legal aid was withdrawn on that ground as well." Dobson J focused on the Agency's reliance on the limitation period rather than the causation problem as the main ground for denying aid, and refused to overturn the Review Panel's decision for that reason alone. However, he held that the conclusion on the causation aspect of the case was open to the Agency, and it is arguable that the appeal could have been decided on that ground alone. ${ }^{37}$

\section{B The English Cases}

In Canada and England there is no comprehensive accident compensation scheme so there might arguably be an additional incentive to make resource-rich defendants liable for the plaintiff's loss, which will otherwise go uncompensated. However, the

\footnotetext{
${ }^{34}$ Ibid, at [68].

${ }^{35}$ Ibid, at [78].

${ }^{36}$ Ibid, at [87].

${ }^{37}$ Ibid, at [190], and at [141] where Dobson J hints that causation would have been a problem for plaintiff SJL.
} 
judges in these jurisdictions have struggled to conceptualise the loss, and it is sometimes necessary to deduct social assistance payments, suggesting that the loss claimed is being dealt with more appropriately by social welfare even where there is no accident compensation.

\section{$1 X v$ Bedfordshire}

The starting point in the English child abuse cases is the House of Lords decision in $X$ $v$ Bedfordshire, although it has been heavily qualified in subsequent cases, as discussed below. ${ }^{38}$ There were five cases consolidated in the appeal, two of which concerned child abuse. In $X v$ Bedfordshire the facts were analogous to Prince: five children were badly neglected by their parents. The childcare authorities received complaints from a neighbour, a grandmother, the police, a GP and a head teacher, and arranged meetings over four years and eight months while doing little beyond occasionally taking the children into temporary care to give the parents a break. $M v$ Newham was analogous to the later New Zealand case $B v$ Attorney-General discussed above: it was alleged that the plaintiff was negligently separated from her mother on the false assumption that her mother's partner had abused her.

The House of Lords struck out the two child abuse cases, which alleged that the child welfare authorities (in England these are controlled by the local councils) owed a duty of care to children whom they believed were in danger of being abused. In other words the Prince duty did not succeed in England. Later, however, the House of Lords allowed a somewhat similar claim in Barrett where the plaintiff was a child who had been taken into care. ${ }^{39}$ The facts were distinguished from $X$ because they involved a child who had already been taken into care. ${ }^{40}$

$X v$ Bedfordshire was appealed to the European Court of Human Rights (ECtHR) in $Z$ $v$ United Kingdom. ${ }^{41}$ The United Kingdom accepted in its submissions that there was a violation of arts $3^{42}$ and $8^{43}$ of the European Convention on Human Rights

${ }^{38}$ X (Minors) $v$ Bedfordshire [1995] 2 AC 633 (HL).

${ }^{39}$ Barrett v Enfield London Borough Council [2001] 2 AC (HL).

${ }^{40}$ The distinction has found favour with several academics, for example Donal Nolan "The liability of public authorities for failing to confer benefits" (2011) 127 LQR 260; Allan Beever Rediscovering the Law of Negligence (Hart Publishing, Oxford, 2007) at 338.

${ }^{41} Z v$ United Kingdom (2002) 34 EHRR 3 (ECtHR).

${ }^{42}$ No one shall be subjected to torture or to inhuman or degrading treatment or punishment.

1. Everyone has the right to respect for his private and family life, his home and his correspondence.

2. There shall be no interference by a public authority with the exercise of this right except such as is in accordance with the law and is necessary in a democratic society in the interests of national security, public safety or the economic well-being of the country, for the prevention of disorder or crime, for the protection of health or morals, or for the protection of the rights and freedoms of others. 
(ECHR), ${ }^{44}$ respectively the right not to be subjected to inhuman treatment and the right to family life. The ECtHR held consistently with its own case law that art 3 together with art $1^{45}$ imposed a positive obligation on states to protect its citizens from inhuman treatment. This was seen as especially important where vulnerable children were involved.

The United Kingdom had accepted in its submissions that there were breaches of arts 3 and 8, possibly because the European Commission of Human Rights (at the time the appeal court immediately beneath the ECtHR) had accepted that there was a breach of art 6, the right of access to the courts. This was based on an earlier case, Osman, in which the ECtHR had found that striking out a cause of action was a breach of art $6 .{ }^{46}$ In $Z$, the United Kingdom convinced the ECtHR that this was based on an "understanding of the law of negligence which has to be reviewed in the light of the clarifications subsequently made by the domestic courts and notably the House of Lords." $" 47$

Conceding the breaches of rights to family life and protection against inhuman treatment may therefore have been a tactical move: possibly the ability to strike out actions was considered more important. However, this had important implications for the development of a common law duty of care in England. The finding in $Z$ that the House of Lords' decision to strike out the pleadings in $X$ breached rights in the ECHR led the English Court of Appeal to recognise a duty of care in East Berkshire, similar to the duty in Prince. ${ }^{48}$ This is discussed below after an analysis of the ECtHR's award in $Z$.

\section{The European Court of Human Rights' decision on damages}

In $Z$, the ECtHR awarded pecuniary and non-pecuniary damages to the plaintiffs for violations of arts 3,8 and 13 . The facts had not been proven at trial, as the case was an appeal from a strike out action. The Court's reasoning in calculating damages was somewhat artificial, but this is not merely a reflection of the lack of evidence at trial. It is part of a pattern, seen clearly in the Canadian cases discussed below, in which courts resort to large round figures in an attempt to guess the loss which the plaintiffs have suffered, sometimes deducting from these figures social assistance benefits. The compensatory principle does not work well in these cases.

\footnotetext{
${ }^{44}$ European Convention on Human Rights (opened for signature 4 November 1950, entered into force 3 September 1974).

${ }^{45}$ The High Contracting Parties shall secure to everyone within their jurisdiction the rights and freedoms defined in Section I of this Convention.

${ }^{46}$ Osman v United Kingdom (2000) 29 EHRR 245 (ECtHR).

${ }^{47} \mathrm{Z}$, above $\mathrm{n} 41$, at 138 .

${ }^{48}$ D v East Berkshire Community NHS Trust [2003] EWCA Civ 1151, [2004] QB 558.
} 
For pecuniary damages in $Z$, the ECtHR accepted submissions from the applicants that they had had their earning capacity impaired. ${ }^{49}$ One of the children, A, was awarded $£ 50,000$ for lost earnings as well as another $£ 50,000$ for future medical costs. The lack of reasoning in the judgment for the particular figure, and the large round identical figures for both kinds of loss suggest a considerable amount of guesswork. The medical costs award was identical to the applicant's suggested minimum. The difficulty of coming to a reasoned lost earnings figure is demonstrated by the applicant's argument, which the ECtHR described as follows: ${ }^{50}$

Assuming that he might otherwise have been able to obtain low-paid manual employment earning $£ 15,000$ per year and a normal working life to age 65 , and taking into account uncertainties and accelerated receipt, he claimed $£ 150,000$ in loss of future earnings.

While the plaintiff's maths can be criticised as rather artificial, the ECtHR failed to explain why it chose the figure $£ 50,000$ rather than $£ 150,000$, leaving the feeling that it was somehow pulled out of the air. The United Kingdom suggested $£ 40,000$ as an appropriate figure for both medical costs and lost earnings. The final award is just under an average of the defendant's and applicant's figures.

For non-pecuniary damages (pain and suffering), the Court awarded $£ 32,000$ to each plaintiff. ${ }^{51}$ This is just under the average of $£ 36,250$ that the applicants pleaded, but just above the average of $£ 25,000$ the UK suggested as appropriate. The two figures average out at $£ 30,625$.

While calculating loss in such cases is always difficult, the choice of awards so close to an average of the applicants' and defendant's suggestions, which are very far apart to start with, is not compelling. It suggests that the awards are not based on a calculation of the loss suffered at all, and are therefore inconsistent with the compensatory principle. They cannot be described as redistributing loss or as "correcting" an injustice caused by loss flowing from the defendant's violation of the plaintiffs' rights (applying the distributive and corrective justice theories of tort law that were described in the last chapter). This emphasises the need for an alternative theory based on vindicating the defendant's duty to protect the plaintiff, without resorting to a fiction that the award is somehow compensatory.

\footnotetext{
${ }^{49} Z$, above n 41 , at $102-103$.

${ }^{50} \mathrm{Ibid}$, at 143 .

${ }^{51} \mathrm{Ibid}$, at 130.
} 


\section{The English development of the duty of care after $Z$}

In East Berkshire the English Court of Appeal concluded that the rule in $X v$ Bedfordshire had been overtaken by $Z$. The Court held that the fact that the Human Rights Act 1998 (UK) did not cover ECHR breaches before October 2000 meant that liability must be imposed at common law: ${ }^{52}$

In the context of suspected child abuse, breach of a duty of care in negligence will frequently also amount to a violation of article 2 or article 8 . The difference, of course, is that those asserting that wrongful acts or omissions occurred before October 2000 will have no claim under the Human Rights Act ... the absence of an alternative remedy for children who were victims of abuse before October 2000 militates in favour of the recognition of a common law duty of care once the public policy reasons against this have lost their force.

English common law is therefore now consistent with New Zealand's and the duty of care which was recognised in Prince and extended in $B$.

The difficulty of the compensatory principle as applied to the duty of care in Prince and East Berkshire manifested itself in Pierre v Doncaster Metropolitan Borough Council. ${ }^{53}$ The plaintiff established at trial that the defendant council had breached its duty to him when it had returned him to his parents after their neglect had led the council to take him to hospital. His father had been abusive and he suffered mental health problems as an adult including emotional unstable personality disorder, agoraphobia and anxiety. However, the judge held that these problems were congenital, and would have occurred without the defendant's negligence and the parent's abuse. Therefore, the plaintiff was awarded damages for the abuse as a child $(£ 25,000)$ but not for any effects as an adult.

In $B v$ London Borough of Ealing, discussed in the previous chapter, the plaintiff alleged that the local authority had failed to protect her from her father's abuse. ${ }^{54}$ However, the proceedings against the authority were stayed while the judge decided the quantum awarded against the second defendant, the father. The judge awarded past loss of earnings of $£ 11,000, £ 22,000$ for future lost earnings, medical expenses for therapy of $£ 2,800$ (including travel) and $£ 1,072$ as the proportion of the cost of the excess alcohol the plaintiff had drunk as a result of the abuse. The judge also awarded damages for pain and suffering, based on the following reasoning: ${ }^{55}$

\footnotetext{
${ }^{52}$ East Berkshire, above n 48, at [83]. Some of the plaintiffs in East Berkshire were parents, and they appealed to the House of Lords: D v East Berkshire Community Health [2005] UKHL 23, [2005] 2 AC373. This decision does not affect the Court of Appeal finding on the duty of care to children.

${ }^{53}$ Pierre v Doncaster Metropolitan Borough Council [2007] EWHC 2968 (QB).

${ }^{54}$ B v London Borough of Ealing [2008] EWHC 1262 (QB).

${ }^{55}$ Ibid, at [17].
} 
To my mind, given the clear evidence of much more frequent abuse [than in Pierre] coupled with the evidence of recognisable psychiatric disorders, but at the same time guarding against what is sometimes referred to as 'double recovery' or 'overlap' and allowing for [the psychiatrist's] view that there are a number of factors relevant to the claimant's psychological symptoms and that it is difficult to be certain as to causation, and recalling what he says ... that there appears to be a family history of anxiety-related difficulties in both father and siblings, taking all those matters into account I award a sum of $£ 33,500$.

This brought the total to $£ 50,372$, roughly twice the award in Pierre. This partly reflected the judge's opinion that abuse in $B$ was worse than in the earlier case, however, the difference in award was largely due to the judge's finding that the abuse was a cause of the psychological illness, which led to lost earnings and medical expenses.

\section{Canadian Cases}

The Canadian Supreme Court has been faced with a string of cases which have tested the limits of the compensatory principle. ${ }^{56}$ The Canadian cases have been usually been dealt with as vicarious liability for intentional torts, rather than negligence, but plaintiffs have continued to frame the damage under the traditional heads of loss, including lost earnings, as in $Z$. The cases are discussed in relation to the different damages issues which have arisen, rather than chronologically as with the New Zealand and English cases.

\section{Causation and apportionment}

One difficulty in causation focused liability has been apportionment. This is the rule that where damage is divisible, the defendant is liable only for that part which he or she caused. ${ }^{57}$ It is an extension of the "but for" test: "but for" the wrong, which part or how much of the damage would the plaintiff have suffered? The application of the test may depend on whether the judge decides the damage is divisible. In $E D G$ the child was abused by a school janitor, and was subsequently abused by a number of family members. ${ }^{58}$ In Blackwater, the child had suffered abuse prior to the abuse which he suffered at school after being removed from his aboriginal community. ${ }^{59}$

\footnotetext{
${ }^{56}$ There is an excellent summary of the Canadian Supreme Court decisions in Sheila McIntyre "Guardians of Privilege: The Resistance of the Supreme Court of Canada to Institutional Liability for Child Sexual Abuse" in Sanda Rodgers, Rakhi Ruparelia and Louise Bélanger-Hardy (eds) Critical Torts (LexisNexis, Markham, 2009).

${ }^{57}$ Wilson \& Horton Ltd v Attorney-General [1997] 2 NZLR 513 (CA).

${ }^{58}$ EDG v Hammer 2003 SCC 52, [2003] 2 SCR 459.

${ }^{59}$ Blackwater v Plint 2005 SCC 58, [2005] 3 SCR 3.
} 
The Supreme Court reached different conclusions in each case when deciding whether to apportion the loss.

In $E D G$ the Court held that neither vicarious nor any other heads of liability were established. However, it went on to consider the apportionment problem. The Supreme Court applied the rule that a defendant is not excused from liability merely because there were other causal factors: "This principle is not confined to cases involving non-tortious preconditions. It applies to any case in which the injuries caused by a number of factors are indivisible." 60 The trial judge's finding that $90 \%$ of the damage was indivisible was a finding of fact and could not be overturned on appeal. $^{61}$

In Blackwater, however, the Court decided that it had to apportion the loss: ${ }^{62}$

Untangling the different sources of damage and loss may be nigh impossible. Yet the law requires that it be done, since at law a plaintiff is entitled only to be compensated for loss caused by the actionable wrong.

The Court explicitly focused on tort's role in shifting loss: "the law requires specific wrongful acts causally connected to damage suffered." 63

The Supreme Court discussed the "thin skull" rule: the defendant takes the victim as found. Therefore the Court may take the prior trauma into account in deciding "the effect of the sexual assault on him, in his already damaged condition". ${ }^{64}$ However, the Court must identify the damage caused by the sexual assault, not the prior trauma, although the trauma may have exacerbated the damage caused by the assault. This is consistent with the rule that "the defendant need not put the plaintiff in a better position than his original position". ${ }^{65}$ Intriguingly the Supreme Court did observe that "all these sources of trauma fused with subsequent experiences to create the problems that have beset [the plaintiff] all his life." Although untangling the causes was difficult, the law required it because "a plaintiff is entitled only to be compensated for loss caused by the actionable wrong." 66 In other words it is the focus on causation that forces the courts to do what "may be nigh impossible.",67

\footnotetext{
${ }^{60}$ EDG, above n 58, at [31].

${ }^{61}$ Ibid, at [33].

${ }^{62}$ Blackwater, above n 59, at para [74], emphasis in original.

${ }^{63}$ Ibid, at [9].

${ }^{64}$ Ibid, at [79].

${ }^{65} \mathrm{Ibid}$, at [78].

${ }^{66}$ Ibid, at [74], emphasis in original.

${ }^{67}$ Ibid.
} 


\section{Future earnings}

To compensate the difficulty of holding down a job in the future as a result of the trauma caused by the abuse, the Supreme Court in Blackwater awarded damages for the loss of future earnings. However, since there was no evidentiary record on which future loss of earnings could be based, the Supreme Court agreed with the Court of Appeal that a "conventional sum" was appropriate. ${ }^{68}$ The "conventional sum" emphasises the impossibility of quantifying the loss claimed: the damages seem intended as a marker that the plaintiff has suffered a wrong which has compromised his ability to sustain employment, rather than as compensation to put him in the position he would have been without the wrong.

The Supreme Court was presented with another difficult causation problem in $H L{ }^{69}$ In this case, the victim had suffered sexual abuse as a child, which the trial judge accepted led to alcohol abuse which caused him employment problems. The main issue in the case was the burden of proof, whether the Saskatchewen Court of Appeal's powers extended to appeal by rehearing, or merely where there was a palpable and overriding error (the answer depended on analysis of the controlling statute $^{70}$ ).

What is important for this thesis is the difficulty in determining the chain of causation, which split the thirteen judges who dealt with the case. The trial judge found causation established and awarded damages for lost earnings, and five of the Supreme Court judges found that this was a question of fact which they could not overturn. However, the Court of Appeal judges lowered the standard of appeal to find that there was no causation, and four of the Supreme Court judges in dissent found that even on the higher standard of palpable error they would have been able to overturn the trial judge's decision because there was no causation. The difficulty of determining causation is revealed in the following summary of the testimony of the defence's expert witness: ${ }^{71}$

Asked whether HL would have become an alcoholic in any event, Dr Arnold stated: "He may have had vulnerability, but except for the exposure to the sexual abuse, may not have developed a substance abuse problem. So I have to be careful when I say that, the risk is there, but except for that triggering event it may not have occurred. We don't know.

\footnotetext{
${ }^{68}$ Ibid, at [96].

${ }^{69}$ HL v Canada (Attorney General) 2005 SCC 25, [2005] 1 SCR 401.

${ }^{70}$ The Court of Appeal Act SS 2000 c C-42.1.

${ }^{71} H L$, above n 69, at [24] emphasis added.
} 
Although the alcohol abuse may also have contributed to the behaviour which led to the plaintiff's time in prison, the Supreme Court unanimously held that he was not able to obtain damages for the foregone earnings during his time spent incarcerated, because that was attributed to his crimes, not to his drinking. Like the $M B$ case discussed below, social assistance benefits were subtracted from the damages.

\section{Collateral benefits}

In $M B$ the Supreme Court was faced with the issue whether to deduct any "collateral benefits" received through social welfare from the "loss" suffered. ${ }^{72}$ The collateral benefits rule reduces damages by the amount of any benefit the plaintiff receives as a result of the wrong. ${ }^{73}$ There are various exceptions, including charitable benefits, which are exempted to avoid disincentivising charitable benevolence.

$M B$ concerned a child abuse victim, to whom the trial judge had awarded loss of income damages, less the amount she received under a state social insurance payment scheme. The Supreme Court by a majority held that the Crown was not vicariously liable for the foster-parents' abuse, but McLachlin CJ, delivering the judgment on this issue for a unanimous court, would have upheld the trial judge's award rejecting the argument that the payments were consistent with the purposes of the charitable benefits exception. ${ }^{74}$ The Chief Justice observed that "it seems unfair to taxpayers to allow certain plaintiffs to recover from these funds and then receive a duplicative payment from a tort award."75

The way the different courts in $M B$ calculated the loss has a similar sense of arbitrariness to the ECtHR's decision in $Z$, discussed above. The trial judge awarded $\$ 172,726.04$ including damages for past opportunity to earn income of $\$ 10,000$, which was calculated by deducting social welfare benefits from a gross amount of $\$ 132,000$. The Court of Appeal held that social assistance benefits should not be deducted, but confusingly substituted a rather different figure of $\$ 50,000$ for past loss of opportunity to earn income. ${ }^{76}$

\section{Summary}

The child welfare cases are beset with difficulties under the traditional loss-based approach in tort law. This approach can be criticised on a number of fronts. First, the courts are unable to quantify the loss even approximately and have to resort to

\footnotetext{
${ }^{72}$ MB v British Columbia 2003 SCC 53, [2003] 2 SCR 477.

${ }^{73}$ The leading New Zealand case is Horsburg $v$ NZ Meat Processors Industrial Union of Workers [1988] 1 NZLR 698 (CA).

${ }^{74} \mathrm{MB}$, above $\mathrm{n} 72$, at [30], emphasis in original.

${ }^{75}$ Ibid, at [33].

${ }^{76}$ Ibid, at [21].
} 
guesswork. Secondly, establishing causation is very difficult (as demonstrated by the apportionment cases). Thirdly, this type of loss is usually barred in New Zealand because of the accident compensation scheme and even in Canada social assistance payments must be subtracted from the lost earnings damages.

The better approach is to award damages for the wrong, rather than for the consequent loss. This is best described as vindicating the community duty to look after children, and the failure by the public authorities as representatives of the community to comply with this duty. 


\section{Applying NZBORA Reasoning in Tort Law}

Much of the support for the vindicatory approach advanced in chapter two is from cases concerned with damages for breach of the New Zealand Bill of Rights Act 1990 (NZBORA), also called Baigent damages. ${ }^{1}$ In this chapter the difficulties of applying the reasoning in the NZBORA cases in tort law are analysed. The chapter argues that although a great deal of tort law is obviously "private", much of tort law protects the same kind of "public law" issues as NZBORA cases. Therefore it is logically difficult to resist applying similar reasoning across both tort law and NZBORA cases.

Leading torts scholars Beever and Lord Hoffmann have both drawn sharp a line between public and private law, placing tort law on one side and judicial review on the other. ${ }^{2}$ They see this line as an important factor in the development of tort law. For example, in chapter two, Beever's argument that it was the private nature of tort law that makes exemplary damages inappropriate was analysed. ${ }^{3}$ This thesis asserts that this "private" conception of tort law is wrong, and that the child welfare cases against public authorities lie on the "public" side of the line. In this chapter one aspect of this public-private divide is analysed: the approach which distinguishes between tort and NZBORA damages by categorising the former as private and the latter as public. This chapter critiques this approach, arguing that it is not possible to distinguish Baigent damages from tort remedies by labelling the former "public law", because part of the common law's public law has always been within tort law.

The main reason for attacking the private-public barrier between NZBORA and tort damages is that once it is removed the case for applying the NZBORA development of a vindicatory remedy in tort law becomes more compelling. However, this has another important consequence for the way the accident compensation bar is applied. If damages for breach of NZBORA are not barred by accident compensation because they are vindicatory, neither should the vindicatory aspect of tort damages be barred. Just as the compensatory and vindicatory parts of NZBORA damages must now be separated since Wilding, ${ }^{4}$ the vindicatory aspect of a tort damages award can also arguably be isolated and protected from the accident compensation bar.

\footnotetext{
${ }^{1}$ After the case in which they were first developed: Simpson v Attorney-General [1994] 3 NZLR 667 (CA) [Baigent's Case], discussed below at text to footnote 16.

${ }^{2}$ For an example of Beever's approach, see Allan Beever "The Structure of Aggravated and Exemplary Damages" (2003) 23 OJLS 87, discussed in chapter two, text to footnote 16. For Lord Hoffmann's approach see Lord Hoffmann "Reforming the Law of Public Authority Negligence" (2009) The Bar Council <www.barcouncil.org.uk>, at [15]; and also Carol Harlow State Liability: Tort Law and Beyond (Oxford University Press, 2004, Oxford) at 32-33 for a discussion of Lord Hoffmann's approach to the public and private law divide.

${ }^{3}$ Beever, ibid. Discussed in chapter two, at text to footnote 16.

${ }^{4}$ Wilding v Attorney-General [2003] 3 NZLR 787 (CA), discussed in chapter two at text to footnote 26.
} 


\section{A The Line between "Public" and "Private" Law}

The image of a clear line between public and private law is a useful metaphor for expressing an idea that there are different policies triggered by actions between individuals as compared to those between the state and the individual. ${ }^{5}$ This difference is important, but an over-emphasis of the line between public and private law is apt to mislead. In particular, it is often not possible in the common law to map out different causes of action in different areas on a chart, marked "private" or "public". 6 While some causes of action, such as judicial review or perhaps contract, may fit the public or private category with relative ease, others, such as tort law or breach of fiduciary duty (which can be used in some jurisdictions to enforce indigenous rights ${ }^{7}$ ) are less easily pinned down. Unfortunately, tort law is sometimes assumed to be private law, compared to "public law" NZBORA damages. The difference becomes important in the child welfare cases, where there is no obvious provision in NZBORA upon which to peg an action. ${ }^{8}$ Being able to bring an action in NZBORA has two important consequences: damages are explicitly "vindicatory", and such an award is not subject to the accident compensation bar. When the sharp division between public and private is, at least partly, dismantled, these consequences can more easily be applied to tort law.

\section{$B$ The Debate in England}

The close relationship between tort damages and awards for breaches of human rights statutes and the potential for cross-fertilisation are highlighted by a debate in England about the relationship between tort law and the Human Rights Act 1998 (UK), which has a specific remedies provision. When the remedies provision was first presented in Bill form, Lord Lester observed that the Act created a new "public law tort." 9 This

\footnotetext{
${ }^{5}$ The classic statement in New Zealand on the difference between "private" tort law and "public" NZBORA damages is probably Hammond J's judgment in Manga v Attorney-General [2000] 2 NZLR 65 (HC), at [122].

${ }^{6}$ For the difficulty of separating out different parts of the common law from others according to the interests which they represent see Stephen Waddams Dimensions of Private Law: Categories and Concepts in Anglo-American Legal Reasoning (Cambridge University Press, Cambridge, 2003).

${ }^{7}$ Claire Charters "The Foreshore and Seabed Act 2004 and Crown Fiduciary Duties to Maori: How does it Compare and What Have Maori Lost?" in Claire Charters and Andrew Erueti (eds) Maori Property Rights and the Foreshore and Seabed: The Latest Frontier (VUW Press, Wellington, 2007) 143.

${ }^{8}$ See chapter two, at text to footnote 52.

${ }^{9}$ Lord Lester of Herne Hill QC "The Impact of the Human Rights Act on Public Law” in Jack Beatson (ed) Constitutional Reform in the United Kingdom: Principles and Practice (Hart Publishing, Oxford, 1998) 105.
} 
phrase has been criticised by Lord Woolf, ${ }^{10}$ but it has continued to be used by Pannick and Lord Lester. ${ }^{11}$ The debate is superficially trivial but contains an important issue: how analogous are damages in tort law and human rights statutes, and can the reasoning in one area be applied in another? ${ }^{12}$

One argument, forcefully presented by Varuhas, is that tort law reasoning should be applied when calculating damages under the Human Rights Act even where this is contrary to precedent from the European Court of Human Rights. ${ }^{13}$ Varuhas argues that this is appropriate because the intentional torts have for many years protected the rights in the Human Rights Act appropriately: "human rights law and torts actionable per se serve similar underlying vindicatory functions and protect common fundamental interests". ${ }^{14}$ However Varuhas rejects the idea that negligence cases can be "public law" because, he argues, they are concerned with compensation rather than vindication: "all of negligence law stems from an underlying compensatory function". 15

As discussed in chapter two this is not entirely accurate: while the compensatory principle works well for most negligence cases, it does not capture all the roles which tort law, including negligence, can perform. In particular it is difficult to explain the child welfare cases as compensating the loss which the plaintiffs suffered as the consequence of the defendant's wrongs. A vindicatory approach, which Varuhas advocates for the intentional torts and the Human Rights Act, should also be applied to those negligence cases which engage public law concerns. This is especially true when the interest which is being vindicated includes a community obligation, which the state as representative of the community has breached.

\footnotetext{
${ }^{10}$ The Right Hon. Lord Woolf of Barnes "The Human Rights Act 1998 and Remedies" in Mads Andenas (ed) Judicial Review in International Perspective (Kluwer Law International, The Hague, 2000) 429.

${ }^{11}$ David Pannick and Anthony Lester "The impact of the Human Rights Act on private law: the knight's move" (2000) 116 LQR 380. See also Iain Steele "Public law liability - the Human Rights Act and beyond (2005) 64 CLR 8.

${ }^{12}$ The classification can be important in deciding whether a court has jurisdiction where the defendant is from the lex fori but is acting in his or her capacity as part of the government of the lex causae where the plaintiff normally resides: see R(Quark Fishing Ltd.) v Secretary of State for Foreign \& Commonwealth Affairs [2003] EWHC 1743.

${ }^{13}$ The European Court of Human Rights is the final court for breaches of the European Convention on Human Rights (opened for signature 4 November 1950, entered into force 3 September 1974), on which the Human Rights Act 1998 (UK) is based.

${ }^{14}$ Jason Varuhas, "A Tort-Based Approach to Damages under the Human Rights Act 1998" (2009) 72 MLR 750, at 765. See also Dan Priel “A Public Role for the Intentional Torts” (2011) Social Science Research Network <www.ssrn.com>, although Priel seems to argue that the public law aspect of tort law is a new phenomenon. The difference between per se torts and other torts is discussed in chapter five.

${ }^{15}$ Varuhas, ibid, at 769.
} 
Varuhas acknowledges that the emphasis on duty in negligence may make the action an attractive mechanism for the protection of positive human rights obligations, but concludes that these duties should be vindicated through an action under the Human Rights Act, to avoid distorting the compensatory principle. In New Zealand this argument is not compelling, because NZBORA lacks the positive rights found in the English Human Rights Act. Negligence may sometimes be the only way of vindicating positive duties in New Zealand.

\section{Baigent's Case}

The reason why the English debate on whether Human Rights Act damages are a "public law tort" has not had much traction in New Zealand has to do with the way NZBORA damages have evolved. In 1994 the New Zealand Court of Appeal in Baigent's Case developed common law damages as a remedy for breaches of NZBORA rights, despite the lack of any damages provision in the Act. ${ }^{16}$ The Court was concerned to emphasise that the damages were not a tort for which the government was vicariously liable, but were awarded against the Crown directly. ${ }^{17}$ While there was important English precedent in Maharaj $^{18}$ which also adopted this approach, the main reason for the way the New Zealand judges divorced the cause of action from tort law was to avoid the immunity provided by s 6(5) of the Crown Proceedings Act 1950. ${ }^{19}$

In Baigent, it was alleged that police had obtained a warrant for the plaintiff's home under the mistake that it was the address of a suspected drug dealer. Although Mrs Baigent was not at home at the time, her son and her neighbour informed police that they had the wrong address, and her daughter, who was a lawyer, told police by telephone that the search was unlawful. It was alleged that the police officer replied: "We often get it wrong, but while we are here we will have a look round anyway." 20 The majority of the Court of Appeal held that any action in tort was barred by s 6(5) if the police officers were executing the warrant in good faith, because it was in pursuance to judicial proceedings. Therefore if a mistaken but genuine belief that they were acting under the authority of the warrant was established at trial there would be no tort action available.

All members of the Court considered that this was insufficient protection of the right in s 21 NZBORA: "Everyone has the right to be secure against unreasonable search or seizure, whether of the person, property, or correspondence or otherwise." New

\footnotetext{
${ }^{16}$ Baigent's Case, above n 1.

${ }^{17} \mathrm{Ibid}$, at 677 per Cooke P, and at 690-691 per Casey J.

${ }^{18}$ Maharaj v Attorney-General of Trinidad and Tobago (No 2) [1979] AC 385 (PC).

${ }^{19}$ Baigent's Case, above n 1, at 708, per Gault J, dissenting.

${ }^{20} \mathrm{Ibid}$, at 672.
} 
Zealanders should be protected against unreasonable search and seizure by the government, even if in unreasonable but good faith pursuance of judicial proceedings. Four of the judges held that in order to protect people against such government actions, a direct action against the Crown could be brought for damages for breach of NZBORA rights. The government would be liable through s 3(2)(c) of the Crown Proceedings Act 1950 which provides for actions against the Crown based on any Acts which are binding on the Crown. The fact that an action is pursuant to judicial proceedings is not a defence to this provision.

Under the majority's approach, NZBORA damages fill a perceived gap, creating a new, public law remedy distinct from tort law. Gault $\mathrm{J}$, in a vigorous dissent, exposed the myth that there had been no public law damages before the advent of NZBORA: ${ }^{21}$

Prior to the enactment of the Bill of Rights Act the recognition of the majority of the declared rights and the provision of remedies had evolved in the common law. The modern declarations of rights and freedoms can be seen as a progression in an evolutionary process rather than a departure from the common law ... The dynamics of the common law will not cease with the enactment of the Bill of Rights Act. There will continue to be the evolution of rights with consequential questions as to the interrelationship between the various rights recognised in the law in different ways.

Gault $\mathrm{J}$ described how tort law had protected the right to bodily integrity and to property and how other rights such as the right to natural justice had been protected in administrative law. He observed that while it was unusual in the common law for rights "to be defined solely in terms of the individual person's relationship with the state" this did not "deny the fact that many of the rights enumerated are already protected in the general law."22 Gault J's judgment captures the way the common law has evolved to protect rights through various different proceedings.

Using the public-private law divide to distinguish NZBORA and tort damages might encourage the view that the development of vindicatory damages for breach of NZBORA rights, as discussed in the last chapter, should not be applied in tort law. However, as Gault $\mathrm{J}$ demonstrated, tort law protects many of the same interests as NZBORA. Both tort law and NZBORA have a role in marking wrongs between public authorities and individuals. The main difference might be that while the rights in NZBORA are limited and an action may only be brought against the Crown, tort law has the potential both to vindicate rights and duties which are not part of NZBORA, and to vindicate wrongs between private individuals. ${ }^{23}$

\footnotetext{
${ }^{21}$ Ibid, at 709. See also Gault J's judgment in Attorney-General v Chapman [2011] NZSC 110.

${ }^{22}$ Ibid, 710.

${ }^{23}$ This last point, that tort law can vindicate wrongs between private individuals, is not analysed in detail in this thesis, but it is discussed briefly in chapter five in the context of the wrongful birth cases.
} 


\section{Ashley and Dunlea}

This section looks at the way one NZBORA case, Dunlea, ${ }^{24}$ has been used in an English tort case, Ashley. ${ }^{25}$ This illustrates the fruitful way reasoning in human rights damages cases can be applied in tort actions, emphasising the public aspect of tort law.

In Ashley the House of Lords was confronted with two issues: whether there was a purpose for assault and battery damages that was not compensatory, and whether a mistaken belief in an imminent danger was a sufficient threshold for self-defence. The police had raided the deceased's flat at about 4.20am. One of the policemen entered the deceased's bedroom with his handgun in the "aim" position and his finger on the trigger. The deceased was out of bed but naked and unarmed. Within seconds he was shot in the neck. By the time paramedics arrived at 4.33 he was not breathing and at 5.15 he was pronounced dead. His father and his son both brought a number of causes of action, on their own behalf and on behalf of the deceased's estate, including in assault and battery and for compensation under the Fatal Accidents Act 1976 (UK). The defendants agreed to pay compensatory damages, including aggravated damages, for most of the causes of action, but moved to have the battery and assault claims struck out.

Lord Scott, in the majority, held that damages under the Fatal Accidents Act were only compensatory. Therefore, even though the defendant agreed to pay all damages under that Act, the battery and assault claim could not be struck out because there was a possibility of vindicatory damages not available under the Act. ${ }^{26}$ His view of tort law was rights based: ${ }^{27}$

Its main function is to identify and protect the rights that every person is entitled to assert against, and require to be respected by, others. The rights of one person, however, often run counter to the rights of others and the civil law, in particular the law of tort, must then strike a balance between the conflicting rights. ... The right not to be physically harmed by the actions of another may conflict with the rights of other people to engage in activities involving the possibility of accidentally causing harm. The balance between these conflicting rights must be struck by the rules and principles of the tort of negligence. As to assault and battery and self-defence, every person has the right in principle not to be subjected to physical harm by the intentional actions of another person. But every person has the right also to protect himself by using reasonable force to repel an attack or to prevent an imminent attack.

\footnotetext{
${ }^{24}$ Dunlea v Attorney-General [2000] 3 NZLR 136 (CA).

${ }^{25}$ Ashley v Chief Constable of Sussex [2008] UKHL 25, [2008] 1 AC 962 (HL).

${ }^{26}$ This aspect of the case is discussed in more detail in chapter five.

${ }^{27}$ Ibid, at [18].
} 
The rules and principles defining what does constitute legitimate self-defence must strike the balance between these conflicting rights.

This passage was in the context of Lord Scott's argument that tort law should not provide a defence of self-defence where there is only a mistaken though genuine belief in imminent danger (the standard in criminal law) because tort law is about balancing rights between people rather than the state punishing individuals. The focus on rights, however, led him to a vindicatory approach which helped to answer the second issue in Ashley, whether the assault and battery claim could be struck out. $^{28}$ Lord Scott drew on a distinction made by Thomas $\mathrm{J}$ in the NZBORA case Dunlea, between loss-based and rights-based damages. ${ }^{29}$ Eschewing the New Zealand distinction between NZBORA and tort damages as "public" or "private", Lord Scott was able to draw on the NZBORA approach in which damages are awarded for the wrong rather than the loss. This is appropriate given tort law's long history in protecting many of the same rights as NZBORA.

Thomas J was dissenting in Dunlea, but his distinction between loss-based and rightsbased damages has since been applied by the New Zealand Supreme Court in the leading NZBORA case. $^{30}$ The difference between the majority and Thomas J lay in the different approach they took to the distinction between tort and NZBORA damages. It is in fact the majority judgment which offers most support for Lord Scott's approach, and for the approach in this thesis.

In Dunlea the plaintiffs were evacuated from a flat adjacent to premises in which a police suspect was hiding. Two of the plaintiffs were cuff linked without being arrested. Initially this was lawful but the final 15 minutes of their detention was held to be arbitrary, and they were awarded $\$ 15,000$ and $\$ 18,000$, respectively. Three of the plaintiffs, who were residents of the flat, were awarded $\$ 1500$ each for an unjustified search of their property. The trial judge, and the majority in the Court of Appeal, did not distinguish between the actions for the tort of false imprisonment and breach of s 22 of NZBORA (the right not to be arbitrarily arrested or detained); or between the tort of trespass to land and breach of s 21 of NZBORA (the right to be secure against unreasonable search).

The difference between the majority and Thomas $\mathrm{J}$ in Dunlea was whether the finding of breaches of NZBORA changed the quantum of the damages awards. Thomas $\mathrm{J}$ held that because the facts involved a breach of NZBORA as well as torts such as false imprisonment and trespass, the damages should be higher in order to vindicate

\footnotetext{
${ }^{28}$ Ibid, at [22].

${ }^{29}$ Ibid, at 22. Lord Scott also cited dicta from Thomas J's judgment in Daniels $v$ Thompson [1998] 3 NZLR 22 (CA).

${ }^{30}$ For example in Taunoa v Attorny-General [2007] NZSC 70, [2008] 1 NZLR 429.
} 
the constitutional nature of the rights in NZBORA. This was based on a bright line distinction between "private" tort law and "public" NZBORA damages: $:^{31}$

Damages for a private wrong do not ordinarily extend to the vindication of the right which has been violated. In a tortious claim the plaintiff claims damages for the breach of a duty owed to the plaintiff. It is in the nature of a private right to remedy a private wrong. In a claim under the Bill of Rights the plaintiff seeks compensation for the breach of a right of a different character.

In constrast, the majority recognised, like Gault $\mathrm{J}$ in Baigent, that tort damages had a similar role to damages for NZBORA and that tort law also vindicates wrongs: ${ }^{32}$

$\ldots$ in the great range of cases where a claim of a breach of the Bill of Rights is made there will also be a claim in tort. So, the present case is not one in which torts were not also established ... or a tortious remedy was defeated by statutory immunities (as in Baigent's Case) ... On the contrary, essentially the same facts lie behind the twin rulings (which are significant in themselves) that the state through its officers has acted in breach of the rights of the plaintiffs, rights long protected by tortious remedies and now affirmed, along with other human rights and fundamental freedoms, in the Bill of Rights.

Arguably, both the majority and Thomas $\mathrm{J}$ have been vindicated in later cases. Thomas J's distinction between vindication and compensation continues to be applied, but it needs to be considered in the light of the majority's conclusion that tort law has for a long time protected the rights in NZBORA, and should continue to do so. In chapter five, it is argued that there is support in existing tort law for vindicatory damages, but Dunlea and Ashley help demonstrate that there are good reasons for applying the vindicatory approach in NZBORA in tort law.

\section{E Summary}

The reasoning in Ashley emphasises the utility of considering NZBORA and tort law as analogous actions: labelling the action for damages for breach of the Human Rights Act or NZBORA a "public law tort" captures an important truth about these damages. The importance for this thesis of this conclusion is that where there are rights which are protected by tort law but not by NZBORA, it is still possible to argue that Baigent-style damages, with their focus on state power, and vindication and deterrence as well as compensation, should be available. This is arguably what is happening in the child welfare cases, both through direct liability in negligence and in vicarious liability for intentional torts: liability is imposed on the state for essentially the same reasons that the state is liable in damages through NZBORA: to vindicate

\footnotetext{
${ }^{31}$ Dunlea, above n 24, at [66].

${ }^{32}$ Ibid, at [38].
} 
individual rights and community duties. This also has important implications for the accident compensation bar.

This chapter has strayed rather far from the child abuse claims. This reflects the fact that there are no obvious rights in NZBORA on which children could peg an action alleging an affirmative duty. In order to take advantage of the vindicatory approach developed in NZBORA damages, it is necessary to analyse the line between tort law and NZBORA actions, and to decide whether this line should prevent developments in NBZORA damages crossing over into tort law. Although the line is important, it is not positioned conveniently between tort law and NZBORA: the common law is more subtle than that. Tort law actions have been doing public law for much longer than NZBORA, and where a tort case raises similar public law concerns to NZBORA cases, a vindicatory approach is justified.

Of course, it may be necessary to vindicate rights between private individuals which lack this public law aspect. In chapter five some of these types of cases are discussed, for example where damages are awarded to vindicate a woman's right to choose whether or not she has children, which might be compromised if a doctor negligently sterilises her. The argument in this thesis is not intended to exclude the potential of vindicatory damages in such cases. However, it is suggested that the public aspect to the child welfare cases lends weight to the argument in favour of the availability of such damages. This is true even in child abuse cases where the defendant is a private sector owner of a child care facility, where there is arguably still a public interest in vindicating the wrong. 


\section{Support for Vindicatory Damages within Existing Tort Law}

In chapter two it was argued that vindicatory damages should be available in tort law, and in chapter three the child welfare cases were analysed as an example where these damages would be useful. The clearest development of a vindicatory approach in damages awards has been in the NZBORA jurisprudence, and therefore in chapter four the distinction between NZBORA and tort damages was analysed. It is suggested that there is nothing in the distinction to prevent the application in tort law of the developments in NZBORA damages.

In this chapter, however, it is argued that there is already existing support for a vindicatory approach within tort law. The chapter falls into two main parts. In the first part, the difference between trespass to the person and negligence is discussed. In negligence, but not in trespass, "damage" (or loss) is required in order to establish liability as well as the remedy. The requirement of damage may make non-loss based damages seem inconsistent with negligence, but it is argued that vindicatory damages should nevertheless be available in negligence as well as trespass to the person.

In the second part of the chapter, the non-loss based damages presently available in tort law are canvassed: these are nominal, aggravated and exemplary damages. These provide some support for the development of an additional head of non-loss based vindicatory damages, but they are insufficient by themselves to vindicate the wrongs underpinning the child welfare cases.

\section{A: Trespass to the Person and Negligence}

The child welfare cases fall into two main groups: those in which it is alleged that the defendant is responsible for the plaintiff's wrong through his or her own negligence, and those in which it is alleged that the defendant is vicariously liable for the battery or assault (trespass to the person) of the abuser. ${ }^{1}$ For example, in the vicarious liability cases the Crown is liable to the plaintiff for the abuser's tort, which will usually be in battery and assault. ${ }^{2}$

In Prince, however, it was not possible to plead battery and assault because there was no relationship between the abuser and the defendant sufficient to establish vicarious

\footnotetext{
${ }^{1}$ Vicarious liability is discussed in more detail in chapter six.

${ }^{2}$ However, it might be advantageous to bring the claim in negligence because trespass and negligence may have different limitation periods. It is unclear whether intentional wrongs can ground an action in negligence in New Zealand, see $S v$ Attorney-General [2003] 3 NZLR 450 (CA) at [120]. There is some support for doing this in Couch Attorney-General (no 2) (on appeal from Hobson v AttorneyGeneral) [2010] NZSC 27, [2010] 3 NZLR 149, at [46], per Blanchard J. However, the difference may be less important in view of the legislative changes brought in by the Limitation Act 2010 (NZ), which is discussed in chapter three at text to 14 .
} 
liability. ${ }^{3}$ The complaint concerned the actions of the Crown itself: whether through its own negligence it had failed to remove the plaintiff from his adoptive parents. ${ }^{4}$ In both negligence and trespass claims the result is the same: the child is harmed. However, in the Prince-type claim the focus is on the Crown's own acts and omissions, rather than whether it is vicariously liable for someone else's abusive acts. There are important differences between direct and vicarious liability addressed in later chapters, but the focus in this section is the difference between trespass and negligence and the implications of this for the remedy.

Unlike negligence, liability for trespass to the person can be established without loss. For this reason these torts are said to be actionable per se. In negligence, on the other hand, the notion of loss is engrained in the question of liability as well as the remedy. As Stapleton has written: ${ }^{5}$

It is a truism that a fundamental requirement for a claim in negligence is that the plaintiff has suffered some past "damage." A breach of duty by the defendant is not enough. The cause of action will not accrue until actionable damage occurs. This damage is said to form the gist of the action.

Including a damage requirement as part of the liability test has implications for the remedy. In negligence the categories of damage which are sufficient to establish liability are narrowly defined, and the loss recoverable as part of the remedy is correspondingly limited. In trespass, however, the lack of a requirement of damage to establish liability is consistent with a more flexible approach to the remedy question.

For example, the tort of assault is established when the defendant causes the plaintiff to have a reasonable apprehension of danger. ${ }^{6}$ If this occurs the plaintiff has a right to potentially substantial damages, even though there is no personal injury. However, in negligence a personal injury would need to be established, which is defined as a physical injury, or a recognised psychiatric illness. ${ }^{7}$

\footnotetext{
${ }^{3}$ Attorney-General v Prince and Gardner [1998] 1 NZLR 262 (CA).

${ }^{4}$ For discussion of whether the Crown can be sued directly in negligence, see Anderson, Stuart "'Grave injustice': the insecure foundations of crown liability for torts in New Zealand" (2009) 12 Otago LR 1.

5 Jane Stapleton "The gist of negligence: Part 1 Minimal actionable damage" (1988) 104 LQR 213.

${ }^{6} T v H$ [1995] 3 NZLR 37 (CA), at 51.

${ }^{7}$ White and Others $v$ Chief Constable of South Yorkshire [1992] 2 AC 455 (HL) p 491, Mustapha v Culligan of Canada Ltd 2008 SCC 27, [2008] 2 SCR 114. In New Zealand the recognised psychiatric injury test applies to secondary victims, see van Soest v Residual Health Management Unit [2000] 1 NZLR 179 (CA). However, the test for primary victims might be different, see $J v$ Crown Health Financing Agency HC Wellington CIV-2000-485-876, 8 February 2008, at 538, quoted in chapter three at test to footnote 29.
} 
The fact that liability can be established without loss emphasises the role that torts actionable per se play in protecting rights whether or not there is any loss, as Giliker has pointed out: ${ }^{8}$

The absence of any requirement of damage indicates that these torts seek to protect the claimant not from purely physical harm, but perceive other interests as inviolable, such as personal integrity and the right to self-determination.

This arguably introduces a vindicatory role into the remedy. For example, if damages in a child abuse case are awarded for battery, it could be argued that they were not intended merely to compensate the loss flowing from the abuse, but also in order to stigmatise the wrong. This would be consistent with the structure of the tort of battery, in which damage is not a requirement of liability.

This approach was adopted by Lord Scott in the House of Lords case Ashley, as discussed in chapter four. ${ }^{9}$ This case provides support for the claim that tort law, or at least the torts of battery and assault, do include a vindicatory purpose. The police officer had shot the plaintiff dead during a drug raid, but claimed self-defence to the tort of battery. However, the defendants accepted liability under the Fatal Accidents Act 1976 (UK) in which damages were strictly compensation based. For this reason, he moved to have the battery and assault pleadings struck out, because they could add nothing to the claims already accepted. The House of Lords by a narrow majority refused to strike out the pleadings.

There are two possible interpretations of the House of Lords' decision not to strike out the pleadings for trespass. First, it is possible that the House of Lords decided that separate non-compensatory damages might be awarded for trespass which were not available for the other causes of action. Lord Scott, for example, emphasized the noncompensatory aspect of vindicatory damages which he held were available for trespass: "Damages awarded for the purpose of vindication are essentially rightscentred, awarded in order to demonstrate that the right in question should not have been infringed at all." 10

However, in a case note on Ashley Palmer and Steele advanced a different interpretation. Rather than assuming that vindicatory damages would be awarded separately in addition to compensatory damages under the Fatal Accidents Act, the

\footnotetext{
${ }^{8}$ Paula Giliker "A 'new' head of damages: damages for mental distress in the English law of torts" (2000) 20 Legal Stud 19, at 27. See also John Murphy "Rights, Reductionism and Tort Law" (2008) 28 OJLS 393.

${ }^{9}$ Ashley v Chief Constable of Sussex [2008] UKHL 25, [2008] 1 AC 962 (HL).

${ }^{10}$ Ibid, at [22].
} 
purpose of the general damages award might change if liability was also for trespass: ${ }^{11}$

... the admission of liability to compensate, accompanied by denial of the trespass, could not at the same time perform a vindicatory role ... The issue is not quantum, but the purpose of the damages awarded.

In England, splitting the general damages explicitly into compensation and vindication is arguably unnecessary. However, in New Zealand the difference is crucial because compensatory damages are usually barred by accident compensation. $^{12}$ As discussed in chapter two, the distinction between the two purposes has been made for NZBORA damages for exactly this reason. ${ }^{13}$ Both interpretations of Ashley offer support for the argument that the torts of battery and assault, at least, have a vindicatory purpose. In New Zealand, it is necessary to distinguish the vindicatory aspect from the compensatory part of the general damages, but this might be less important in England.

\section{B Support for a Non-compensatory Approach in Negligence}

As outlined above, a vindicatory approach fits well with the rationale of the intentional torts because they are per se torts. However, in negligence damage is a requirement of both liability and the remedy. Are vindicatory damages, which are focused on vindicating wrongs rather than compensating loss, appropriate in negligence?

There is, perhaps surprisingly, authority for such an award in the House of Lords case Rees. ${ }^{14}$ In that case the House of Lords awarded a separate award to recognise the wrong to the plaintiff, who had conceived a child after the defendant performed her sterilisation operation negligently. There is also support for a vindicatory approach in the earlier House of Lords decision Chester $v$ Ashfar, in which the plaintiff suffered a complication in surgery which she had not been advised of. ${ }^{15}$ In that case the House of Lords developed the rules of causation to vindicate the plaintiff's rights, rather than making a separate award to recognise the wrong. While the contexts of these cases are quite different from the child welfare cases analysed in this thesis, they are both useful examples of the way judges have responded to the intuitive desire to vindicate the plaintiff's wrong through damages awards, even though it may be difficult to identify a type of "loss" which negligence can easily compensate.

\footnotetext{
${ }^{11}$ Phil Palmer and Jenny Steele "Police Shootings and the Role of Tort" (2008) 71 MLR 801, at 810 emphasis in original.

${ }^{12}$ New Zealand's accident compensation scheme is discussed in chapter two.

${ }^{13}$ See the discussion in chapter two, text to footnote 26.

${ }^{14}$ Rees v Darlington Memorial Hospital NHS Trust [2004] 1 AC 309, [2004] 1 AC 309.

${ }^{15}$ Chester v Afshar [2004] UKHL 41, [2005] 1 AC 134.
} 


\section{Rees v Darlington}

Rees was a wrongful birth decision delivered by the House of Lords in 2003, in which the mother sued for a negligent sterilisation, claiming the costs of raising the healthy child whom she had conceived as a result of the negligent advice that her sterilisation operation had been successful. In 1999 the House of Lords had held in McFarlane that the damages of raising a healthy child could not be recovered because they were not quantifiable and because it would be "morally offensive". ${ }^{16}$ However, in 2001 the English Court of Appeal had allowed the extra cost of raising a disabled child. ${ }^{17}$ In Rees, the plaintiff was partially blind, and feared that she would not be able to raise a child.

In Rees the judges took as a starting point the position that McFarlane is an exception to the orthodox rules of negligence. If the normal rules of foreseeability and causation applied, the defendant would be liable for the cost of raising the child, which the sterilisation was specifically designed to prevent. ${ }^{18}$ However, building on dicta by Lord Millett in McFarlane the majority awarded a "conventional award" of $£ 15,000$ which each judge described slightly differently, although the overall focus was on the loss of autonomy which the plaintiff suffered because her decision not to have children was compromised.

The Rees award is consistent with the type of vindicatory damages advanced in this thesis. ${ }^{19}$ However, the award is problematic because it does not fit well with typical awards of general damages for negligence, which are compensatory.

Although the majority insisted that the award was a simple "gloss" on McFarlane, the minority drew attention to the lack of support in the case law for such a "conventional" sum. Lord Hope found the "lack of any consistent or coherent ratio in support of the proposition in the speeches of the majority disturbing." 20 It was contrary to the normal rule of tort law that a plaintiff is entitled to be put back in the position she would have been but for the tort. The damages were neither nominal,

\footnotetext{
${ }^{16}$ MacFarlane v Tayside Health Board [2002] 2 AC 59 (HL). However, the High Court of Australia by a 4-3 majority decided differently: Cattanach v Melchior (2003) 199 ALR 131 (HC).

${ }^{17}$ Parkinson $v$ St James and Seacroft University Hospital NHS Trust [2001] EWCA Civ 530, [2002] QB 266 at [58].

${ }^{18}$ Rees, above n 14, Lord Bingham at [4], Lord Nicholls at [12] Lord Hutton at [87] (dissenting), Lord Scott at [143].

${ }^{19}$ For a similar analysis of Rees, Norman Witzleb and Robyn Carroll "The role of vindication in torts damages" (2009) 17 Tort L Rev 16, at 37.

${ }^{20}$ Rees, above n 14, at [74].
} 
general, nor punitive, but rather were "entirely novel" and "contrary to principle." Lord Steyn described it as "a radical and most important development". ${ }^{22}$

While the approach of the majority is favoured in this thesis, Lord Steyn's observation is accurate. An award that recognises a wrong and the denial of the plaintiff's autonomy is an entirely novel head of damages in negligence. This has led to some divergence in the interpretation of the Rees award. It could be interpreted, consistently with the vindicatory approach favoured in this thesis, as a noncompensatory award to mark the wrong. This is how Lord Bingham in the majority viewed it: ${ }^{23}$

The conventional award would not be, and would not be intended to be, compensatory. It would not be the product of calculation. But it would not be a nominal, let alone a derisory, award. It would afford some measure of recognition of the wrong done.

An alternative approach would be to rephrase the interest vindicated by the Rees award as some kind of loss. Nolan has suggested that the award should be seen as compensating the plaintiff's loss of autonomy. ${ }^{24}$ The difference between the two approaches is that in the first, damages are intended as recognition that the plaintiff's autonomy has been undermined, and in the second, they are designed to compensate the plaintiff's lost autonomy.

This second interpretation is analysed in some detail below before concluding that the vindicatory interpretation should be preferred.

\section{The advantages of Nolan's approach}

Analysing the Rees award as compensation for lost autonomy fits with the compensatory principle of negligence. It is consistent with the emphasis placed by the judges that the damages were not for the costs of raising the child but for the plaintiff's autonomy. ${ }^{25}$

Autonomy here signifies the ability of plaintiffs to choose the lives they lead. It is an interest in liberty, the freedom to make choices and to carry them out. Dworkin has

\footnotetext{
${ }^{21}$ Ibid, at [73].

${ }^{22}$ Ibid, at [43].

${ }^{23}$ Ibid, at [8].

${ }^{24}$ Donal Nolan "New Forms of Damage in Negligence" (2007) 70 MLR 59.

${ }^{25}$ See, for example, Lord Millett, Rees, above n 14, at [123].
} 
offered the following definition, which captures the value of a person being able to reach their own decision and to act on it without external control. ${ }^{26}$

... the value of autonomy ... derives from the capacity it protects: the capacity to express one's own character-values, commitments, convictions, and critical as well as experiential interests - in the life one leads. ... It allows us to lead our lives rather than be led along them, so that each of us can be, to the extent a scheme of rights can make this possible, what we have made of ourselves.

This definition of autonomy explains the interest protected in Rees: the plaintiff decided not to have any children, and the defendant's negligence undermined her ability to act on that decision. The decision was one which resonates with many of the qualities usually associated with autonomy. It was reached after critical reflection: she made the decision because she had poor eyesight and thought she would be unable to take care of the child. It related to her independence and her own sense of sovereignty: the ability to control her body's capacity to conceive children.

One advantage of this approach is that it might also be possible to describe the "damage" in the child abuse cases as a loss of autonomy. For example the plaintiff in Prince argued that the failure to investigate the neglect of his adoptive parents led to damage which included loss "of the chance to realise his potential". ${ }^{27}$ The allegation was effectively that he was never in control of his life: his adulthood was controlled by the neglect he suffered as a child. In the Australian case Trevorrow, the plaintiff, a victim of that country's controversial indigenous children policies: ${ }^{28}$

... claimed that his removal from his natural family, and his placement with [foster parents], was unlawful. He claimed that the separation from his natural mother and family, and the manner in which he was reunited with his natural family, all contributed to a loss of cultural identity, depression, alcoholism, poor health, poor relationships and erratic employment history.

\section{The disadvantages of this approach}

Despite the advantages of analysing the Rees award as compensating autonomy (or in the child welfare cases the capacity to develop autonomy) this approach has two main problems. First, at least in the child abuse cases it disadvantages children who are autonomous. One of the greatest difficulties with applying the compensatory

\footnotetext{
${ }^{26}$ Ronald Dworkin Life's Dominion: An Argument about Abortion, Euthanasia and Individual Freedom (HarperCollins, London, 1993) at p 224, quoted in Chester v Afshar, above n 15, at [18], discussed below. See also Gerald Dworkin Theory and Practice of Autonomy (Cambridge University Press, Cambridge, 1988).

${ }^{27}$ Prince, above n 3, at 265.

${ }^{28}$ State of South Australia v Lampard-Trevorrow [2010] SASC 56, (2010) 106 SASR 331.
} 
principle to the child abuse cases is that it distinguishes between child abuse victims who suffer "loss" and those that do not. The types of loss discussed above in relation to the child abuse cases raise the question: have child abuse victims who do not suffer "depression, alcoholism, poor health, poor relationships and erratic employment history" suffered "loss" in the sense required by negligence? Is it necessary to identify a "loss" at all in such cases?

The second problem with Nolan's compensatory approach is that it puts too much strain on the compensatory principle. It is possible to rephrase every damages award in terms of loss, but the exercise is not always terribly edifying. The compensatory principle is that damages put the plaintiff in the position they would have been but for the loss, however it is difficult to imagine how $£ 15,000$ would put the plaintiff in Rees in the position she would have been but for the damage to her autonomy.

While it has long been accepted that the attempt to put the plaintiff in the same position they would have been but for the wrong is somewhat fictional and limited by the ability of damages awards to do this, describing the attack on a woman's autonomy through negligent sterilisation as a compensatable loss can become farcical. The attraction of this interpretation of Rees lies in the temptation to fit everything within the existing compensation paradigm, rather than an accurate analysis of the award in the case.

The better interpretation of Rees is that doctors performing sterilisations (or vasectomies) owe their patients duties to take care in order, partly, to protect the patient's autonomy, which is exercised by the choice not to have any more children. This is vindicated by an award of a "conventional sum" when the duty is breached, but the consequent "loss" (the cost of raising the child) is not compensated. A similar approach can by analogy be applied to the child welfare cases. When the duty in Prince was breached the community obligations to take care of children were also compromised, and vindicatory damages are appropriate as a marker of the wrong, rather than compensation.

\section{The problem of "damage"}

However, introducing a non-compensatory damages award for negligence in the child abuse cases comes up against the problem identified earlier in relation to negligence, where damage is the "gist" of the action. In negligence, as opposed to trespass, damage must be identified in order to establish liability as well as establishing quantum for damages. If the award is not designed to compensate damage, then is there any damage which establishes liability? 
In Rees itself negligence was established because damages were awarded for the pain, suffering and inconvenience of the pregnancy. Therefore, there was arguably a personal injury (presumably the pregnancy) which was caused by the breach of the doctor's duty, which helped establish the action in negligence. This emphasises the point that the damage required to establish negligence is not the same as the damages awarded. ${ }^{29}$ In Rees the damages awarded went beyond the "damage" which established the action.

A similar point may be made with the child welfare cases. Where it is alleged that a public authority such as New Zealand's Child Youth and Family Services fails to remove a child from abusive parents, it is only those children who do suffer abuse who are able to claim, even under the vindicatory approach advanced in this thesis. If the authority receives a complaint that a child is being abused but negligently fails to investigate, the child has no action if the complaint is unfounded and there is no abuse. If damage was not the "gist" of the action, the breach of the duty of care would give rise to an action whether or not the child had suffered abuse. This would be inconsistent with the underlying duty which it is argued these cases vindicate: the community obligation to look after children. The community obligation is not breached if children are not abused or neglected.

\section{Chester v Afshar}

This section considers the 2004 House of Lords case Chester v Afshar, ${ }^{30}$ which Lord Scott in Ashley gave as an example of vindication in tort law. ${ }^{31}$ In Chester, decided before Rees, the House of Lords stretched the causation rules in order to vindicate the plaintiff's right to be informed of the risks of the medical procedure which she consented to on the defendant's advice. However, rather than adapting the causation rules, the better approach would arguably have been to award vindicatory damages, applying the approach developed subsequently in Rees.

The defendant doctor had failed to advise Miss Chester of a $1 \%-2 \%$ risk of surgery that eventuated and left her paralysed. The trial judge found that she would have continued with the surgery even if she had been correctly advised, but that she would have thought about it more seriously and delayed the operation for a few days. As the risk would have been the same on any other day, it was more likely than not that the risk would not have eventuated on that other day, and therefore she would not have suffered the injury.

\footnotetext{
${ }^{29}$ Stapleton, above n 5, at 217; Nolan, above n 24, at 61 .

${ }^{30}$ Chester, above $\mathrm{n} 15$.

${ }^{31}$ Ashley, above n 9, at 22.
} 
As all the judges in the House of Lords acknowledged, this placed a great deal of strain on the traditional test of causation, because it was the operation, and not the failure to warn, which caused the damage. ${ }^{32}$ However, they also all accepted the importance of the duty to warn patients of any risk in surgery. Lord Steyn said that "a patient's right to an appropriate warning from a surgeon when faced with a surgery ought normatively to be regarded as an important right which must be given effective protection whenever possible."33 The difference between the majority and minority seemed to lie in whether compensatory damages were an appropriate way to remedy the underlying duty.

The minority criticised the remedy as too large for the wrong which the plaintiff suffered. While the duty was important, it did not need to be vindicated by the entire cost of the paralysis which the plaintiff had suffered. Lord Bingham held that: ${ }^{34}$

The patient's right to be appropriately warned is an important right [but] I do not for my part think that the law should seek to reinforce that right by providing for the payment of potentially very large damages.

Lord Hoffmann suggested that a modest solatium might be appropriate "to vindicate the patient's right to choose for herself." 35 However, he thought that it would be difficult to find a suitable figure and it would probably be outweighed by the costs of litigation. While it might be true that vindicatory remedies are arguably not worth the trouble of litigation, that is a decision for the plaintiff to make, not the courts.

Chester $v$ Afshar emphasises the need for a specifically vindicatory remedy in the judiciary's toolbox. The approach of the House of Lords led to damages well out of proportion to the wrong and stretched causation principles unnecessarily. It introduces a distinction between patients who are not fully informed but who would have had surgery on the day originally planned, and those like Miss Chester who would have delayed it by a few days. While both patients in these situations would have similar rights breached, the duty is only "vindicated" in Miss Chester's case. In the other situation, there would be no effective remedy. ${ }^{36}$

\footnotetext{
${ }^{32}$ For example Lord Hope in Chester, above n15, at [61].

${ }^{33}$ Ibid, at [17]; see also Lord Hope at [54]; and the dissenting judges Lord Bingham at [5] and Lord Hoffmann at [33].

${ }^{34}$ Ibid, at [9].

${ }^{35}$ Ibid, at [33] and [34].

${ }^{36}$ Lord Hoffmann made a similar point, ibid, at [35]: doctors who breach their duty would not be liable if someone else did the operation.
} 


\section{Existing Separate Awards of Non-compensatory Damages in Tort Law}

The Rees award was part of the general damages awarded to the plaintiff. However, the better approach would have been to separate out such damages from the general damages, which are compensatory. As argued in chapter two, they would only be necessary where the compensatory damages are insufficient to vindicate the wrong.

This section analyses nominal, aggravated and exemplary damages. These are separate from general damages, and there is arguably a vindicatory aspect to these awards. However, while these damages offer support for the proposition that there is a vindicatory role within existing tort law, these are not appropriate awards for vindicating the underlying duty in the child welfare cases, where the defendant is someone other than the abuser.

\section{Nominal damages}

One obviously non-compensatory award available in some torts is nominal damages. These are very small sums (between $£ 1$ and $£ 5$ in England) which can be awarded where there is no damage, either simply to recognise the wrong, or in order to attach costs. $^{37}$ They are available in per se torts, but it is not always clear which torts are per se and which are not. Actions in trespass are per se, but not all actions in case are per se. ${ }^{38}$ Nominal damages are not available in negligence.

Nominal damages are sometimes awarded in order to vindicate a wrong where there is no loss. For example, in the 1944 case Constantine $v$ Imperial Hotels Learie Constantine, one of the first West Indians to play in English county cricket, was denied lodging in a hotel for himself and his family, although he had booked in advance. ${ }^{39}$ The staff directed him to a nearby hotel owned by the same management, possibly in response to the complaints of American servicemen who were staying there and who disliked sharing accommodation with the dark skinned Constantine. He suffered no "loss", because he was able to stay in an alternative accommodation.

However, he sued for the breach of the old common law duty that required innkeepers to receive and lodge travellers who request their hospitality. The judge held that, although the action was in case, it was a per se tort. Therefore he awarded nominal damages of five guineas, because otherwise the wrong would go unremedied.

\footnotetext{
${ }^{37}$ Harvey McGregor McGregor on Damages (18th ed, Sweet \& Maxwell, London, 2009) at ch 10.

${ }^{38}$ For the difference between actions in trespass and actions on the case, see Peter Handford "Intentional Negligence: A Contradiction in Terms?" (2010) 32 Syd L Rev 29, and the authorities Handford cites at footnote 19.

${ }^{39}$ Constantine v Imperial Hotels Ltd [1944] KB 693.
} 
In cases like Constantine, nominal damages act as a kind of declaration that a wrong has occurred, even though there is no loss. However, in most actions on the case (including negligence) nominal damages are usually unavailable.

The issue was of some importance in Watkins, in which the plaintiff, a prisoner, alleged misfeasance in office when the prison officers refused to give him his mail without reading it first. ${ }^{40}$ Unfortunately reading his mail was not the type of special damage necessary to establish the tort, which is in case, and the House of Lords held that the tort was not made out. In the Court of Appeal, however, Brooke LJ argued that nominal damages were available when important constitutional rights were violated, even where the tort was case, relying on Ashby $v$ White. ${ }^{41}$ In Ashby the plaintiff sued the defendant in case for preventing him from exercising his right to vote. He was awarded nominal damages. The judge in Constantine had relied on Ashby for the rule that nominal damages could be awarded for an action on the case.

In the House of Lords Lord Rodger demonstrated that the rationale of Ashby could not have been that it concerned a constitutional right, because that would have taken the case beyond the court's jurisdiction at the time. ${ }^{42}$ Instead, it should be viewed as a property law case, vindicating the plaintiff's important property right (to vote).

However, aside from the difficulty of identifying when nominal damages are available, they may not be sufficient to vindicate the wrong. They might be useful as a peg for costs or exemplary damages but they are so small that alone they might seem to trivialise the wrong, rather than vindicating it. While vindicatory damages should be small they must also be significant enough to make it clear that the wrong is taken seriously.

\section{Aggravated damages}

Although nominal damages might be too small to be vindicatory, there is no such limit on aggravated and exemplary damages. In Couch (No 2) McGrath J described the difference between aggravated damages and exemplary damages in the following way: ${ }^{43}$

Aggravated damages may be awarded to compensate for additional suffering for injury to feelings and dignity that results from the manner of a defendant's conduct. Exemplary damages are separate and are awarded to punish and deter a wrongdoer...

\footnotetext{
${ }^{40}$ Watkins $v$ Secretary of State for the Home Department [2004] EWCA Civ 966, [2005] QB 883.

${ }^{41}$ Ashby $v$ White (1703) 2 Ld Raym 938.

${ }^{42}$ Watkins $v$ Secretary of State for the Home Department [2006] UKHL 17, [2006] 2 AC 395, at 416.

${ }^{43}$ Couch v Attorney-General (No 2) (on appeal from Hobson v Attorney-General) [2010] NZSC 27; [2010] 3 NZLR 149, at [215].
} 
Aggravated damages are perhaps the most nebulous and controversial head of damages separate from general damages. Unlike exemplary damages, which have received repeated analysis from the judiciary and have been steadily narrowed, aggravated damages remain unclear except for a general consensus that they are compensatory. ${ }^{44}$ This has the important consequence that they are therefore barred by the New Zealand's accident compensation scheme when they arise directly or indirectly from personal injury. ${ }^{45}$ Although there is commentary suggesting the damages compensate the dignity interest of the plaintiff (discussed below), which arguably hints at a vindicatory purpose, the overwhelming consensus that the damages are compensatory means they are unlikely ever to escape the accident compensation bar. The importance of ensuring that vindicatory damages in tort law are not barred by accident compensation leads to the conclusion that they should be developed separately from aggravated damages.

Several commentators have advocated that aggravated damages be judicially abolished. ${ }^{46}$ If aggravated damages are merely additional compensation to reflect the extra hurt to the defendant caused by the "aggravating" manner of the wrong, then the argument is convincing: this type of extra "loss" can easily be included in the general award of damages, and it may create difficulties trying to separate it out. This is in addition to the difficulties of separating aggravated damages from exemplary damages.

While there is judicial consensus that the damages are compensatory, there is little agreement on what is being compensated. The passage quoted above by McGrath $\mathrm{J}$ summarises the traditional understanding as focusing on the hurt feelings which the plaintiff subjectively suffered. ${ }^{47}$ However, Beever and Murphy have given a more sophisticated analysis which would give rise to an objective conception of aggravated damages. ${ }^{48}$ Under this analysis, aggravated damages are awarded to vindicate the plaintiff” "dignity interest".

Under Beever's and Murphy's analysis, the dignity interest is the interest people have as rights-holders: when plaintiffs are treated as if they have no rights, their dignity is undermined. The quality of being human is what justifies rights, therefore when a

\footnotetext{
${ }^{44}$ See Attorney-General v Niania [1994] 3 NZLR 106 (HC), at 111 and New South Wales v Ibbett [2006] HCA 57, (2006) 229 CLR 638, at [31].

${ }^{45}$ Donselaar v Donselaar [1982] 1 NZLR 97 (CA) at p 107.

${ }^{46}$ See for instance the often quoted criticism in Peter Cane The Anatomy of Tort Law (Oxford University Press, Oxford, 1997) at 114.

${ }^{47}$ See RFV Heuston and RA Buckley Salmond and Heuston on the Law of Torts (21 st ed, Sweet \& Maxwell, London, 1996) at 503; Huljich v Hall [1973] 2 NZLR 279 (CA) at 287.

${ }^{48}$ Allan Beever "The Structure of Aggravated Exemplary Damages" (2003) 23 OJLS 87; John Murphy

"The nature and domain of aggravated damages" (2010) 69 CLJ 353. See also Peter Birks

"Harassment and Hubris: The Right to an Equality of Respect" (1997) 32 Irish Jurist 1.
} 
defendant treats a plaintiff as having no rights their dignity as a human being is compromised. Beever summarises this argument as follows: "The wrong is an injury to the victim's moral dignity that results from the defendant's denial that the victim is entitled to respect as a moral person."

Beever expands on this using three categories of wrong devised by the German philosopher Hegel, two of which, he argues, involve harm to the dignity interest. The first is where the wrongdoer treats the victim's rights with contempt, even though acknowledging that he or she is a rights-holder. The second category is where the rights-holder is treated as if he or she has no rights at all, but rather "as a mere thing." 49 Both Murphy and Beever argue that the difference between this type of behaviour and an "ordinary" wrong is found in the intention of the defendant: "even a dog can tell the difference between being stumbled over and being kicked." For Murphy, dignity: ${ }^{50}$

...entails the irreducible, intrinsic worth of each human being simply by virtue of their personhood [Treating them without dignity] is treating them as though they were somehow worth less than oneself, or simply worthless."

In many ways, this conception of aggravated damages can be described as having a vindicatory function. It involves awarding damages when the defendant treats the plaintiff's rights with contempt, and serves as a reminder that the plaintiff is a rights holder and should be treated as such with respect. However, this is not the same as the vindicatory damages advanced in this thesis. Beever's and Murphy's theory focuses on how the defendant treats the plaintiff as a rights holder. However, in the child welfare cases the underlying wrong which needs to be vindicated is the community duty to take care of children. It is difficult to describe a public authority who negligently fails to investigate a complaint of child abuse as treating the child's rights with contempt. Nor can an authority which unknowingly and without negligence employs a paedophile to look after children be said to treat the rights of the children in its care dismissively.

\section{Exemplary damages}

Exemplary damages might sometimes serve a vindicatory purpose. ${ }^{51}$ In both of the two decisions delivered by New Zealand Supreme Court in Couch, Elias CJ delivered minority judgments in which she developed a theory of exemplary damages which would embrace a role for vindication. Susan Couch had been severely beaten by a

\footnotetext{
${ }^{49}$ Beever, ibid, at 89 .

${ }^{50}$ Murphy, above $\mathrm{n} 48$, at 361 .

${ }^{51}$ For an overview of exemplary damages in New Zealand, see Bevan Martin "Exemplary Damages" in Blanchard J (ed) Civil Remedies (2nd ed, Brookers, Auckland, 2011).
} 
parolee who was working with her, and she sued the Attorney-General alleging that the parole officer was negligent when releasing the attacker, Bell, and placing him in an inappropriate work environment. It was not clear whether the proceedings alleged direct negligence or vicarious liability. In the first decision the Supreme Court unanimously refused to strike out the proceedings, holding that it was arguably that there was a duty of care. ${ }^{52}$ However Elias CJ and Anderson J dissented in approach. In the second decision, the Court went on to consider in what situations exemplary damages were available. ${ }^{53}$ The majority held that they were available to punish the defendant, but only if there was subjective recklessness.

Elias CJ took a rather different approach, arguing that exemplary damages could be utilised by the courts for all the non-compensatory purposes of tort law. She outlined this approach in the first Couch decision: "a stand-alone claim for exemplary damages may serve the non-compensatory ends of tort liability and is necessary to respond to 'the community's sense of justice'. ${ }^{54}$ These purposes would include vindication: "Exemplary damages in such circumstances may meet the non-compensatory ends of tort law in determining unsafe conduct, vindicating those who are injured, and raising standards." 55

However, the majority's decision that exemplary damages are only available where there is subjective recklessness makes it difficult for them to be awarded against the Crown, which in New Zealand is only liable in tort vicariously. ${ }^{56}$ Since vicarious liability is based on an employment relationship between the defendant and the wrongdoer, and is not triggered by any fault on the defendant's part, the defendant can never be described as subjectively reckless. ${ }^{57}$ Therefore it is extremely unlikely that the Crown could ever be liable for exemplary damages. This is important because exemplary damages are the only damages not currently barred by accident compensation in New Zealand. Therefore where the Crown is responsible for an accident causing personal injury, there is no tort remedy.

The real difference between the minority and majority in Couch may have been the place they saw for tort law in regulating the relationship between the state and the individual. $^{58}$ In the second Couch decision the majority emphasised a private law

\footnotetext{
${ }^{52}$ Couch v Attorney-General (on appeal from Hobson v Attorney-General) [2008] 3 NZSC 45, [2008] 3 NZLR 725.

${ }^{53}$ Couch (No 2), above n 43.

${ }^{54}$ Couch, above n 52, at [10].

55 Ibid, at [11].

${ }^{56}$ Crown Proceedings Act 1950 s 6(1)(a). However, this provision is not always strictly applied, and sometimes the courts appear to hold the Crown liable directly, see Anderson, above $\mathrm{n} 4$.

${ }^{57}$ Vicarious liability is discussed in chapter six.

${ }^{58}$ Matthew Windsor "Exemplary damages and government liability" [2010] NZLJ 171.
} 
conception of tort law. ${ }^{59}$ Elias CJ's description of exemplary damages in contrast reflected a wider role for torts, which might include public interests: ${ }^{60}$

Exemplary damages ... are available only when the amount required to make good the plaintiff's loss and any additional affront to him (properly reflected in aggravated damages) is unequal to mark the affront to community values occasioned by the defendant's conduct."

She emphasised that tort law was not simply a "loss distribution mechanism,"61 and favoured a more flexible test for exemplary damages where the allegation was that a public authority failed to discharge its statutory functions properly: ${ }^{62}$

... in modern society, in which the public may reasonably rely on the discharge of responsibilities by those entrusted with public power and resources, it may be that inaction which amounts to shrugging off responsibility in some circumstances is as accurately described as high-handed or arbitrary even if the harm that eventuates is not consciously foreseen.

Elias CJ's conception of a public law role for exemplary damages is consistent to some extent with the English approach to exemplary damages. In England, Lord Devlin's speech in Rookes $v$ Barnard remains the leading authority in this area. ${ }^{63}$ Lord Devlin confined the situations in which exemplary damages could be awarded to three categories, one of which was where exemplary damages are necessary "in restraining the arbitrary and outrageous use of executive power." 64

Rookes $v$ Barnard itself was not a case involving government power, but Lord Devlin gave as an example of this category the 1763 decision Wilkes $v$ Wood. ${ }^{65}$ In that case the plaintiff's house had been searched and his papers removed under a general warrant and he brought proceedings in trespass. Pratt CJ instructed the jury that: ${ }^{66}$

Damages are designed not only as a satisfaction to the injured person, but likewise as a punishment to the guilty, to deter from any such proceeding for the future, and as a proof of the detestation of the jury to the action itself.

While Elias CJ's more public law approach to tort law is consistent with the argument in this thesis, it is not suggested here that all the non-compensatory ends of tort law

\footnotetext{
${ }^{59}$ Couch (No 2), above n 43, for example at [58].

${ }^{60}$ Ibid, at [19], emphasis added.

${ }^{61}$ Ibid, at [20], citing Richardson J in Taylor v Beever [1982] 1 NZLR 81 (CA), at 90.

${ }^{62}$ Couch (No 2), ibid, at [27].

${ }^{63}$ Rookes v Barnard [1964] AC 1129 (HL), see McGregor, above n 37, at ch 11.

${ }^{64}$ Rookes, ibid, at 1223.

${ }^{65}$ Wilkes $v$ Wood (1763) Lofft 1. Discussed in Rookes, ibid, at 1222.

${ }^{66}$ Wilkes, ibid, at 18-19.
} 
should be subsumed within exemplary damages. Vindication is a distinct purpose, although it may at times overlap with punishment. It may be necessary when both exemplary and vindicatory damages are awarded to adjust the amount to reflect the possibility of overlap. However, the two heads of damages are not the same: vindication looks not just at the behaviour of the defendant and whether this merits punishment, but at the wrong as a whole and whether this needs to be marked by damages.

\section{Summary}

While non-compensatory vindicatory damages might be somewhat controversial in tort law, the discussion in this chapter demonstrates that they are not entirely novel. Nominal, aggravated and exemplary damages are non-compensatory, and although it is not suggested that they satisfy the need in tort law for a separate vindicatory award, they have a vindicatory flavour.

Cases like Rees and Chester $v$ Afshar illustrate a vindicatory purpose within negligence. The approach in Rees, in which non-compensatory damages were awarded in recognition of the wrong to the plaintiff and reflected the damage to her autonomy interest, is consistent with the approach advanced in this thesis. Therefore while vindicatory damages might be unusual in tort law, there is an existing foundation on which they can be developed. 


\section{Vicarious Liability}

This thesis began with the assertion that the compensatory principle cannot explain the child protection cases. The first half of this thesis included an analysis of the damages issues which arise in these cases, and then proceeded to advance an alternative vindicatory approach, in which the remedy is for the wrong, not the consequence. This remedy would not be calculated by the amount of loss suffered.

In the remaining chapters the focus is on liability issues. The courts have developed tort doctrines in the child protection cases by recognising duties of care where there is a failure to exercise a statutory power, and by stretching the doctrine of vicarious liability to include intentional wrongs such as sexual abuse. This thesis argues that vindicatory damages are appropriate whether liability is direct or vicarious, and that some of the developments in the liability issues might be explained by the vindicatory approach outlined in the earlier chapters.

As emphasised at the beginning of the thesis, the child welfare cases involve liability for third party wrongs. This may happen in two ways. The plaintiff may bring proceedings directly alleging that the Crown's own negligence failed to prevent the abuse, or (more commonly) the plaintiff may use a doctrine such as vicarious liability to attribute the abuser's torts to the Crown. In chapters seven and eight the focus is on the issues arising from direct negligence actions. This chapter is about vicarious liability.

Vicarious liability traditionally arises where an employee commits a tort within the scope of his or her employment. For example, an employer may be liable vicariously for a truck driver in his employ who negligently drives into another motorist while delivering merchandise for the employer. The development of vicarious liability reflects the fact that the employer is more likely to be able to bear the cost of the accident than the wrongdoer, and that as the employer derives some advantage from the employee's activity it is fair that the risk of that activity should be allocated to the employer. The issue discussed in this chapter is whether the vicarious liability doctrine can also accommodate a vindicatory purpose: should vindicatory damages be awarded against a defendant who is only vicariously liable?

\section{A The Argument Against Vindicatory Damages for Vicarious Liability}

There is an important characteristic of vicarious liability that points away from the availability of non-loss based damages. Vicarious liability effectively attributes the tortfeasor's wrong to the defendant whether or not the defendant is at fault: liability is strict. While it might be appropriate to force a faultless employer to pay for the loss of a victim who is equally innocent when the real wrongdoer is impecunious, forcing 
the defendant to pay non-loss based damages is less easily justified. For this reason, New Zealand courts have held that exemplary damages, which are not loss-based but are intended to punish the defendant, should not be awarded vicariously. In Couch (No 2) Tipping J observed: ${ }^{1}$

When one person is acting on behalf of another, the wrong is seen for the purposes of compensation as having been committed both by that person and by the other. But the policy behind awarding compensatory damages against a person on the basis of vicarious liability does not mean that exemplary damages should be similarly awarded. There is no policy basis for punishing someone for the conduct of another unless the first person's conduct itself also qualifies for punishment. People should not be vicariously liable for punishment on account of the conduct of someone else just because that conduct renders them liable to compensate the plaintiff.

\section{B Two Counter-arguments}

In this chapter two possible solutions are suggested in response to the problem involved in awarding non loss-based damages vicariously. First, it is argued that the claim that vicarious liability is not based on fault is exaggerated. Courts in Canada and England have imposed liability on the owners of residential child care facilities where employees have abused the children in the defendant's care, partly because the defendant itself owed a duty to the child. ${ }^{2}$ In other words, the defendant's liability is triggered not by its relationship with the employee, but by its own independent duty of care to the plaintiff. Vindicatory damages might be appropriate in such cases to recognise the breach of the defendant's duty.

There is a second possible argument, however. Stevens and Murphy have both argued that liability in the child welfare cases should be based on breach of a nondelegable duty, not vicarious liability. ${ }^{3}$ This approach is based on a distinction between vicarious liability which arises when the defendant is an employer of the tortfeasor, and non-delegable duties which are triggered by the relationship between the defendant and the victim. A non-delegable duty arises when the defendant assumes responsibility for the plaintiff's welfare.

\footnotetext{
${ }^{1}$ Couch v Attorney-General (No 2) (on appeal from Hobson v Attorney-General) [2010] NZSC 27; [2010] 3 NZLR 149, at [215], at [158].

${ }^{2}$ See Bazley v Canada [1999] 2 SCR 534, Lister v Hesley Hall Ltd [2001] UKHL 22, [2002] 1 AC 215, discussed below.

${ }^{3}$ Robert Stevens "Non-delegable Duties and Vicarious Liability" in Jason W Neyers, Erika Chamberlain and Stephen GA Pitel (eds) Emerging Issues in Tort (Hart Publishing, Oxford, 2007) 331; John Murphy "Judicial Foundations of Common Law Non-Delegable Duties" in Jason W Neyers, Erika Chamberlain and Stephen GA Pitel (eds) Emerging Issues in Tort (Hart Publishing, Oxford, 2007) 369 .
} 
For example, the owner of a crèche may be vicariously liable for the negligence of his or her employees if they injure a child. The owner may also have a non-delegable duty to take care of the child which would be breached if the child was injured by a stranger as well as by an employee. ${ }^{4}$ Liability arises because of the responsibility the defendant has assumed to the child, not because of the relationship with the employee.

In both arguments, liability is imposed because of the relationship between the defendant and plaintiff, not because of the relationship between the defendant and the wrongdoer. Since liability is triggered by the defendant's duty to the plaintiff, vindicatory damages are appropriate even though the employer did not personally cause the wrong. The difference between the two arguments is that in the first, the cases where the defendant has its own duty to the plaintiff are seen as a subset of vicarious liability. In Murphy's and Stevens' approach these cases would form a separate cause of action. In this thesis it is this second approach which is preferred, but the alternative first argument may be more realistic in light of the case law in this area.

\section{The Child Welfare Cases and Fault}

Vicarious liability typically arises in the child welfare cases where the defendant runs a child care facility and an employee abuses a child in the defendant's care. For example, in Blackwater $v$ Plint the plaintiff had been removed from his aboriginal community and placed in a special school run by the government of Canada and the United Church of Canada, where he had been physically and sexually abused. In 2005, the case reached the Supreme Court. ${ }^{5}$

The church and the government were both held vicariously liable for their employee's torts. The issue was whether liability could be apportioned unequally. The trial judge apportioned the damages $75 \%$ to the Crown and $25 \%$ to the church. The Crown argued that, if vicarious liability was truly no-fault liability, it was impossible to apportion liability unequally. The Supreme Court was forced to concede that vicarious liability implied some fault, and that this justified greater liability on the part of the Crown because the trial judge had found that the Crown was in a better position to control the tortfeasor. On whether vicarious liability was no-fault, McLachlin CJ, writing for the Court, observed: ${ }^{6}$

The most compelling view is that while vicarious liability is a no-fault offence in the sense that the employer need not have participated in or even have authorised the employee's particular act of wrongdoing in another sense it implies fault ... the

\footnotetext{
${ }^{4}$ This example is based on a similar one used by Stevens, above n 3, at 364 .

${ }^{5}$ Blackwater v Plint 2005 SCC 58, [2005] 3 SCR 3.

${ }^{6} \mathrm{Ibid}$, at [69].
} 
degree of fault may vary depending on the level of supervision. Parties may be more or less vicariously liable for an offence, depending on their level of supervision and direct contact.

The conclusion that vicarious liability in the child welfare cases implies some fault is the result of developments in vicarious liability which began with the 1999 Supreme Court of Canada decision Bazley. ${ }^{7}$ In that case, and in subsequent decisions from the House of Lords and the New Zealand Court of Appeal, the courts began to emphasise the relationship between the defendant and plaintiff when imposing vicarious liability, rather than the relationship between the defendant and wrongdoer, which is the focus of the original test.

\section{The Original Test: the Relationship between the Defendant and Wrongdoer}

In Bazley, the tortfeasor Curry had been employed by the defendant non-profit organisation in its residential care facilities for children between the ages of six and twelve. He had been required to interact with the plaintiff as a parent would do, which included bathing and tucking in at bedtime. Like most child abuse victims, Bazley found that the abuser was not worth suing, and turned to the employer instead. However, Bazley had an obvious difficulty in establishing vicarious liability against his abuser's employer. Vicarious liability requires that the wrong is within the scope of the employment. It is difficult to conceive of child abuse as within any legitimate employment contract. The scope of employment test is set out in more detail before a discussion of the Supreme Court's decision, in which they held the employer vicariously liable.

The traditional vicarious liability test is in two parts: there must be a relationship of employer and employee (or master and servant), and the employee must have committed the wrong in the course of his employment. While the scope of the employment rule caused problems in cases like Bazley, the first rule has also been distorted in New Zealand by imposing liability on the Crown for the torts of foster parents, who are not employees. ${ }^{8}$

In this chapter the second limb of the test (scope of the employment) is analysed before a discussion of the employment relationship limb. This is because the first cases to establish vicarious liability successfully for child abuse involved tortfeasors who were obviously employees. Therefore it was only the second limb, the "scope of the employment" requirement, which required analysis. Later cases such as the New Zealand Court of Appeal decision $S v$ Attorney-General, in which the alleged abuse

\footnotetext{
${ }^{7}$ Bazley, above $\mathrm{n} 2$.

${ }^{8}$ S v Attorney-General [2003] 3 NZLR 450 (CA).
} 
involved foster parents, focused on the first limb of the vicarious liability test, but did so against the background of the earlier cases. ${ }^{9}$

Although cases like $S \vee$ Attorney-General involve the government as defendant, which is the main focus of this thesis, in a number of the cases discussed below, including Bazley, the defendants are private sector charities. Because of the way the test developed, it is not possible to discuss only those cases brought against public authorities. However, it is easy to imagine similar facts arising where the defendant is a public authority.

\section{E Course of Employment}

Traditionally, employers were only liable for their employee's torts if they were within the scope of employment. Beginning with the Canadian Supreme Court decision Bazley in 1999 the appellate courts in Canada, England and New Zealand have developed vicarious liability in order to allow child abuse victims to sue. The modern development focuses on the relationship of the defendant and victim, making damages which vindicate the defendant's duty appropriate.

The second limb of the vicarious liability test is the "Salmond test". It comes from Salmond's textbook on tort law, first published in 1906. The test is as follows: ${ }^{10}$

A master is not responsible for a wrongful act done by his servant unless it is done in the course of his employment. It is deemed to be so done if it is either (a) a wrongful act authorised by the master, or (b) a wrongful and unauthorised mode of doing some act authorised by the master.

The difficulty of the course of employment test for child abuse cases is, as discussed above, that it is difficult to describe deliberate abuse as within the course of employment, or as an unauthorised mode of doing an authorised act. ${ }^{11}$ This difficulty is a reflection of the fact that liability arises from the relationship between the defendant and wrongdoer. This relationship both triggers vicarious liability and limits its scope: the employer will be liable only for wrongs within the relationship from which the liability arises. This can be compared to liability for non-delegable duties, in which the scope of the duty is determined by what the defendant assumed responsibility for.

\footnotetext{
${ }^{9} S v$ Attorney-General, ibid.

${ }^{10}$ John W Salmond The Law of Torts (1st, Stevens and Haynes, London, 1907) at 83, emphasis in original.

${ }^{11}$ Lister, above n 2, at [68].
} 


\section{Bazley and Jacobi}

In 1999 the Supreme Court of Canada confronted this issue in the child abuse context in two cases, Bazley and Jacobi. ${ }^{12}$ By this time the law was clear from a line of authority following the 1912 case Lloyd that employers could be liable for their employee's theft of property. ${ }^{13}$ The Supreme Court assumed that Lloyd was decided upon vicarious liability and concluded that it would be wrong to hold employers liable for their employee's thefts but not their abuse of children: "Surely a distinction is not to be drawn attributing a higher standard to the way society looks after its jewellery than its children." 14 However, as discussed below it is not clear that Lloyd was based on vicarious liability, and it is arguable that Bazley should have been decided upon a different basis, such as non-delegable duties.

The Supreme Court handed down a single judgment in Bazley delivered by McLachlin J, which purported to follow the Salmond test but effectively overhauled it by reformulating the test as whether there was a close connection between the opportunity which the employer has created and the wrong which the employee committed (the enterprise risk test). ${ }^{15}$ McLachlin $\mathrm{J}$ held that the defendant in Bazley had materially increased the risk of child abuse by placing Curry in a position of parent-like responsibility with vulnerable children, in situations of intimacy. ${ }^{16}$

The Supreme Court released a second decision on the same day as Bazley, in which it decided by a majority of four to three not to impose vicarious liability. In Jacobiv Griffiths the Vernon Boys' and Girls' Club was, unlike the Foundation in Bazley, a recreational rather than a residential facility. Children attended for sports and other activities after school and on Saturdays. There were occasional outings. The Club employed Griffiths as its Programme Director, whose task it was to organise the activities and outings. The plaintiffs, Joy and Randy, were siblings, and attended the Club to play hockey and participate in gymnastics. They were both abused by Griffiths, who pleaded guilty to criminal charges before the civil proceedings, although all of the abuse took place away from school premises and (except for one incident) outside school hours.

It is difficult to distinguish Bazley and Jacobi based on the enterprise risk test. In both cases it is hard to see how the provision of child care facilities for children like

\footnotetext{
${ }^{12}$ Bazley, above n 2; Jacobi v Griffiths [1999] 2 SCR 570.

${ }^{13}$ Lloyd v Grace, Smith \& Co [1912] AC 716 (HL).

${ }^{14}$ Bazley, above n 2, at [24].

${ }^{15}$ Ibid, at [41].

${ }^{16}$ Ibid, at [58].
} 
Bazley increased the risk of child abuse, as Neyers and David Stevens has pointed out: ${ }^{17}$

It does not make sense to say that the existence of any particular institution increases the risk of paedophilia ... since the alternative to the institution is the street. Surely the children are more vulnerable and the paedophile more empowered if they are left on the street.

Bazley is based on an assumption that vicarious liability can be imposed for an employee's intentional wrongs, applying cases such as Lloyd. However, as suggested in the next section, Lloyd should be analysed as an example of liability for breach of a non-delegable duty. Such an approach would also explain the difference in result between Bazley and Jacobi.

\section{Lloyd and non-delegable duties}

In Lloyd a firm of solicitors was held liable for the dishonesty of their clerk, who had persuaded a client to transfer property to him, which he used to his own advantage. The modern importance of Lloyd is its value as precedent for the rule that employers can be liable for the intentional torts of their employees. However, controversy surrounds the argument that this case is an example of vicarious liability, as opposed to agency or liability for breach of non-delegable duty.

Salmond himself appears to have viewed the case as changing the rules of vicarious liability: ${ }^{18}$

It was long supposed that where the fraud or other wilful wrongdoing of the servant was committed for his own benefit and not on his master's behalf, his master was not responsible. It has now been decided by the House of Lords, however, in Lloyd $v$ Grace Smith \& Co that this is not the case ...

\footnotetext{
${ }^{17}$ Jason W Neyers and David Stevens "Vicarious Liability in the Charity Sector: an Examination of Bazley v Curry and Re Christian Brothers of Ireland in Canada" (2005) 42 Can Bus LJ 371, at 402, arguing that there should have been no liability in Bazley because it discourages charities without whom the plaintiffs would have been in a worse position. For an argument that there should have been liability in both Bazley and Jacobi see Sheila McIntyre "Guardians of Privilege: The Resistance of the Supreme Court of Canada to Institutional Liability for Child Sexual Abuse" in Sanda Rodgers, Rakhi Ruparelia and Louise Bélanger-Hardy (eds) Critical Torts (LexisNexis, Markham, 2009).

${ }^{18}$ John W Salmond The Law of Torts (4th ed, Stevens and Haynes, London, 1916) at 99, cf the third edition (1912) at 93, which was published before Lloyd. However, see the note by Frederick Pollock on the case at (1913) 29 LQR 10, which emphasises the agency aspects and the relationship of the plaintiff and defendant. See also Pettersson v Royal Oak Hotel Ltd [1948] NZLR 136 (CA) where a customer threw a glass at a bar attendant and the attendant threw part of it back at him, negligently injuring another customer (the plaintiff). The Court of Appeal held that the employer was vicariously liable although the attendant was motivated by personal resentment. Lloyd was cited as authority for this in the oral argument. However, it is not clear that this case would be decided the same way today: Stephen Todd (ed) The Law of Torts in New Zealand (5th ed, Brookers, Wellington, 2009) at 1048.
} 
In a 1964 case Lord Denning appears to have treated the case as one of agency. ${ }^{19}$ However, Bowstead and Reynolds on Agency seems to treat the case as an example of vicarious liability, but acknowledges that "in common speech" the clerk might be "more appropriately described as [an] agent". ${ }^{20}$

Modern torts scholars have argued that Lloyd should be seen as an example of liability for breach of non-delegable duty. ${ }^{21}$ On this interpretation liability would be based on the interaction between the solicitor and the client, rather than any employment or agency relationship between the solicitor and the clerk.

This analysis can be elaborated using Cane's distinction between relational liability and outcome liability. ${ }^{22}$ Relational liability is based on the relationship between the defendant and the wrongdoer, while outcome liability is triggered when the defendant guarantees an outcome to the plaintiff (or that an outcome will not happen). Under outcome based liability it does not matter whether or not the defendant's agent or employee committed the wrong, or whether the defendant caused the wrong: liability is based on the defendant's assumption of responsibility that an outcome will (or will not) occur. The defendant is at fault for not preventing the wrong.

\section{Lewis and independent contractors}

Non-delegable duties are typically used to impose liability on defendants for the wrongs of independent contractors, because vicarious liability is traditionally only available for the wrongs of employees. However, non-delegable duties should not be seen as a gap-filler designed to prevent defendants escaping liability by contracting out; rather, they are distinct from vicarious liability because they are based on the relationship between the defendant and plaintiff, not that between defendant and tortfeasor.

For example, in the Canadian case Lewis, the Ministry of Transportation and Highways engaged a contractor to remove the rocks from a cliff bordering a highway which they were responsible for repairing. ${ }^{23}$ The work was done negligently, and one of the remaining rocks fell and killed a passing motorist. Because the work was done by contractors, not employees, the Ministry was not vicariously liable.

\footnotetext{
${ }^{19}$ Rooke v Viscount Chelmsford [1965] 1 QB 248 (CA), at 261.

${ }^{20}$ Peter Watts and FMB Reynolds Bowstead and Reynolds on Agency (19th ed, Sweet \& Maxwell, London, 1010) at 487.

${ }^{21}$ See Neyers, above n 17, at 394; Murphy, above n 3, at 376.

${ }^{22}$ Peter Cane The Anatomy of Tort Law (Oxford University Press, Oxford, 1997) at 46. Note though that Cane suggested that outcome liability was very rare in the common law, at 49.

${ }^{23}$ Lewis (Guardian ad litem of) v British Columbia [1997] 3 SCR 1145.
} 
The Supreme Court held that the Ministry had a non-delegable duty: once it had decided to do the repair work on the cliff, it was liable for any negligence whether this was done by an employee or an independent contractor. The Ministry derived its powers to repair the road from statute, and the non-delegable duty arose from the statutory framework. Cory $\mathrm{J}$ said: ${ }^{24}$

The imposition of personal liability on the Ministry for its contractor's failure to discharge the duty to take due care ancillary to the Ministry's statutory power flows from this section and the overall general scheme of the applicable statutes.

Liability for breach of the non-delegable duty was triggered by the relationship between the Ministry and the users of the highway, as McLachlin J, in a concurring judgment, observed: ${ }^{25}$

To determine whether a non-delegable duty should be imposed, the Court should examine the relationship between the parties and ask whether that relationship possesses elements that make it appropriate to hold the defendant liable for the negligence of its independent contractor.

The focus on the relationship between the defendant and plaintiff distinguishes Lewis from cases of vicarious liability. In vicarious liability, the plaintiff may have no idea who the defendant is because they are dealing with the employer. Where there is a non-delegable duty it is the wrongdoer who may be unknown. As Cory J pointed out, users of the highway rely on the Ministry to repair the highway. ${ }^{26}$ However, they may not know who the Ministry engaged to do the work.

\section{Bazley and Jacobi explained with non-delegable duties}

While the risk enterprise test cannot explain cases such as Bazley because it is not obvious that the risk to children is increased when charities provide residential care facilities for emotionally troubled children, the result may be more readily explained with the non-delegable duty analysis described in relation to Lloyd and Lewis. On this analysis, liability would be imposed where the defendant had assumed responsibility to the plaintiff and the wrong which occurred was within the scope of the duty. The defendant in Bazley assumed responsibility for the care of the plaintiff; it guaranteed the outcome that Bazley would be safe while on its premises. Therefore it is liable when that outcome does not occur.

\footnotetext{
${ }^{24}$ Ibid, at [26].

${ }^{25}$ Ibid, at [53].

${ }^{26}$ Ibid, at [32].
} 
As Stevens has argued, the non-delegable explanation of Lloyd also explains the result in Jacobi: $:^{27}$

... the Supreme Court of Canada in Bazley v Curry reached the right result for the wrong reasons ... it stretches credulity to suggest that running a non-profit residential care home for emotionally troubled children increases the risk of children being abused ... if the claims in Bazley and Jacobi had been seen as based upon voluntarily assumed duties that care would be taken of the children, the difference in result is readily explicable. The scope of the duty undertaken must be ascertained. What was the club in Jacobi undertaking to do? There was an undertaking that care would be taken of the children at the club, but they are not assuming a duty to care for the child once he or she goes home.

\section{Lister and assumption of responsibility}

Stevens' argument is especially compelling when applied to the House of Lords case Lister, in which the judges applied the "close-connection" test from Bazley but explicitly introduced ideas to do with assumption of responsibility. In Lister the warden at a boarding school for boys had abused one of the children in his care. Like the home in Bazley, the facilities were residential, and it was meant to feel like a home rather than an extension of school. The House of Lords adopted what it saw as the ratio of Bazley and Jacobi, the connection between the tort and the authorised action. The judges argued that this was consistent with the real Salmond test, by returning to the first edition of Salmond for the following passage: ${ }^{28}$

... a master ... is liable even for acts which he has not authorised, provided they are so connected with acts which he has authorised, that they may rightly be regarded as modes.

Lord Steyn observed: "Salmond's explanation is the germ of the close connection test adumbrated by the Canadian Supreme Court in Bazley." 29

Most of the Law Lords in Lister also discussed the duty which the defendants owed to the plaintiffs. Lord Steyn observed that "It becomes possible [under the Lister approach] to consider the question of vicarious liability on the basis that the employer undertook to care for the boys through the services of the warden..."30 Lord Clyde observed that Bazley illustrates a "situation where the employer has assumed a relationship to the plaintiff." 31

\footnotetext{
${ }^{27}$ Stevens, above n 3, at 361-362; emphasis in original.

${ }^{28}$ Salmond, above n 10, at 83-84, quoted in Lister, above n 2, at [15]. Emphasis added.

${ }^{29}$ Lister, ibid.

${ }^{30}$ Inid, at 227 per Lord Steyn.

${ }^{31}$ Inid, at [46] emphasis added; see also Lord Hutton at [54].
} 
The emphasis on assumption of responsibility and the voluntary undertakings by the defendant is consistent with the non-delegable duty approach advocated by Stevens and Murphy. The focus is on the relationship between the defendant and plaintiff, as in liability for breach of a non-delegable duty, rather than on the relationship between the defendant and wrongdoer. The duty is consistent with Cane's "outcome liability" in which the defendant is liable because it failed to ensure that the plaintiff would be kept safe, even though it had assumed responsibility for this outcome.

In child abuse cases like Bazley and Lister vicarious liability is problematic because the abuse is not within the scope of the course of employment. However, the defendants in both cases assumed responsibility to ensure the children in their care were looked after, and this duty was breached when the children were abused, even though the defendants did not cause the abuse through their own negligence. Therefore liability for breach of a non-delegable duty is appropriate. Vindicatory damages are appropriate in such cases because liability is based on the defendant's own duty. It is misleading to describe such liability as not based on fault.

\section{F Stretching the Employment Relationship: S v Attorney-General}

As discussed at the beginning of the chapter, establishing vicarious liability for intentional wrongs is the second part of a two-limb test: the plaintiff must also establish that the tortfeasor and the defendant were in an employment relationship.

In July 2003 the New Zealand Court of Appeal in Sv Attorney-General unanimously imposed vicarious liability on the Crown for the torts of foster parents although there was no employment relationship and no remuneration. ${ }^{32}$ However, the judges differed in their reasoning. The majority held that foster parents were agents of the Crown and that this established vicarious liability in the same way as an employment relationship. Tipping $\mathrm{J}$, in the minority, preferred to see foster parents as a sui generis class for which the defendants could be held liable. ${ }^{33}$

This section argues that the agency analysis is not compelling. Although agency is one way of making the defendant liable for the wrongs of a third party, it is distinct from vicarious liability. Crown liability for foster parents is best explained as arising from the responsibility the Crown assumes when it takes children into its care and then places them with foster parents, consistent with the non-delegable duty analysis discussed above. Liability vindicates the Crown's duty to ensure the children's wellbeing.

\footnotetext{
${ }^{32} S v$ Attorney-General, above n 8, at [64].

${ }^{33}$ Ibid, at [102].
} 


\section{Is agency an established ground of vicarious liability?}

In his 1967 monograph on vicarious liability, Atiyah wrote: "there is no more controverted proposition than that a principal is generally liable for the torts of an agent committed within the scope of his authority." 34 Since then the controversy seems to have been resolved in favour of a bright line between agency and vicarious liability, with the New Zealand Court of Appeal in $S v$ Attorney-General a striking exception. $^{35}$

Unlike vicarious liability, where liability is secondary, agency imposes primary liability on a principal. Agency arises when one person: ${ }^{36}$

... manifests assent that the other should act on his behalf so as to affect his relations with third parties, and the other of whom similarly manifests assent so to act or so acts pursuant to the manifestation.

Liability is primary because the agent acts on behalf of the principal, as Stevens has pointed out: "If someone is authorised to make a statement on my behalf, the statement is mine regardless of whether the words come out of my mouth." ${ }^{37}$ This difference between primary and secondary liability makes assuming a general principle of vicarious liability for principals and the torts of their agents problematic. It is better to treat agency and vicarious liability as distinct doctrines, both of which attribute liability to the defendant for the wrongs of a third party, either an employee or an agent. ${ }^{38}$

Agency concepts have been utilised in two situations of vicarious liability: the motorcar cases and the fraud cases. This does not provide support for the Court of Appeal's reasoning in $S v$ Attorney-General, however. Neither of these situations suggests that there is a general principle of vicarious liability for principals and the torts of their agents which could apply to the abuse cases.

\section{(a) Motor-car cases}

Quasi-agency relationships were used for a while in a line of motor car accident cases, in which the driver of a car was said to be the owner's agent, and the owner was made vicariously liable. Giliker has pointed out that this was probably because the owner

\footnotetext{
${ }^{34}$ PS Atiyah Vicarious Liability in the Law of Torts (Butterworths, London, 1967) at 99.

${ }^{35}$ Cf Michael A Jones (ed) Clerk \& Lindsell on Torts (20th ed, Sweet \& Maxwell, London, 2010) at 398, Paula Giliker Vicarious Liability in Tort: A Comparative Perspective (Cambridge University Press, Cambridge, 2010) at 110.

${ }^{36}$ Bowstead, above n 20, at 1.

${ }^{37}$ Robert Stevens "Why do agents 'drop out'?” [2005] LMCLQ 101, at 103.

${ }^{38}$ Giliker, above n 35, at 109-110.
} 
was more likely to be insured than the driver, and that this doctrine has become redundant in England now that third-party motor car insurance is mandatory: ${ }^{39}$

... the policy justification for using agency to extend vicarious liability to the loan of motor vehicles has virtually disappeared. It remains an odd remnant of the common law, originating in horse and buggy cases and developing, in the twentieth century, to respond to the needs of victims of motor vehicle accidents. As such, it adds little to our understanding of the principles of vicarious laibility, save the willingness of the common law courts to extend the benefits of vicarious liability regardless of principle (and legal coherence) to achieve the aims of social justice.

(b) Fraud cases

The other kind of vicarious liability cases in which agency concepts have been used are fraud, such as Lloyd discussed above. ${ }^{40}$ Giliker has argued that agency concepts are relevant to fraud because the tort involves victim participation. It must be reasonable for the plaintiff to rely on the employee's deception: ${ }^{41}$

Thus, where the victim relies on statements which he knows or believes to be made by an employee acting outside the scope of his actual or apparent authority, then the courts will refuse to impose vicarious liability.

However, the introduction of the agency concept of authority is only relevant to the scope of the employer's vicarious liability for the employee's tort: it does not extend the vicarious liability doctrine to principals and agents. There is no justification for imposing vicarious liability generally on all principals for the torts of their agents within the scope of their authority. The majority's approach in $S v$ Attorney-General should therefore be rejected, whether or not foster parents can be described as agents. Nor is Tipping J's approach, which would deem foster parents and the Crown as a sui generis form of vicarious liability, preferable: once liability is imposed on relationships beyond employment, it becomes impossible to draw the line anywhere.

\section{Non-delegable duties applied to S v Attorney-General}

Instead of viewing Crown liability for foster parents as vicarious, the better analysis is that the Crown has a non-delegable duty to take care of children. This is consistent with the reasoning (but not the ratio) in $S$, which focused on the relationship of the employer and victim, rather than that between the employer and the wrongdoer. The majority observed: ${ }^{42}$

\footnotetext{
${ }^{39}$ Giliker, above n 35, at 116 .

${ }^{40}$ Ibid, at 176.

${ }^{41}$ Ibid, at 177.

${ }^{42} S v$ Attorney-General, above n 8, at [68].
} 
The Superintendent had a duty imposed upon him by statute to take care of the children. He was obliged to fulfil that duty by placing them in suitable private homes where there was supposed to be adherence to practices in accordance with a Departmental manual and continued Departmental monitoring. The Department had a right of inspection and a right to remove any child at any time. The children were said, in the words of the long title to the Child Welfare Act, to be "specially under the protection of the State". That protection cannot have been intended to diminish when a fostering arrangement was made.

The importance of establishing vicarious liability rather than a non-delegable duty based on assumption of duty may have been that the Crown is only liable in tort law vicariously. However, as observed in the analysis of Baigent in chapter four, it is possible to sue the Crown for primary liability under an Act under s 3(2)(b) of the Crown Proceedings Act 1950: "Any wrong or injury for which the Crown is liable in tort under this Act or under any other Act which is binding on the Crown". As discussed above in relation to Lewis, non-delegable duties have been imposed in Canada on public authorities where they have statutory duties. ${ }^{43}$ It is arguable that non-delegable duties could be imposed on the Crown to enforce the "duty imposed upon [it] by statute", consistently with the reasoning in $S v$ Attorney-General. However, this argument has not been accepted in Canada, as discussed below.

\section{KLB, EDG and non-delegable duties}

In Canada, the Supreme Court in 2003 released two decisions on Crown liability for child abuse. In $K L B$ it considered the same issue as the New Zealand Court of Appeal in $S$, but reached the opposite conclusion, holding that the Crown was not vicariously liable for the torts of foster parents (the oral submissions were heard before $S$, but the decision was delivered afterwards). ${ }^{44}$ The plaintiff was one of four children whose parents were unable to care for them: the father was an abusive alcoholic and the family lived in extreme poverty. The children were placed together with two different foster parents, one after the other. There was direct negligence in the placements, as the Ministry should have known that the foster parents were likely to be abusive, as indeed turned out to be the case. In one family, KLB was sexually abused by one of the parents' adopted sons.

The Supreme Court applied the traditional employment test of control when determining whether there was the kind of relationship which gave rise to vicarious liability. It emphasised the degree of independence and lack of oversight which foster parents have in the way they care for their foster children. While the Court did not hold that only employment relationships could ground vicarious liability, it contrasted

\footnotetext{
${ }^{43}$ Lewis, above n 23.

${ }^{44}$ KLB v British Columbia 2003 SCC 51, [2003] 2 SCR 403.
} 
the relationship of foster parents and the Crown with the relationship in the House of Lords case Lister: ${ }^{45}$

In that case, the warden was clearly an employee acting on behalf of the company ... The warden received a salary, instead of the cost-recovery payments made per child to foster parents.

In $E D G$ the Supreme Court found against the plaintiff's claim for damages against the Crown and the Board of Trustees of the school where she had been assaulted by the night janitor. The Court analysed whether the Board could be liable for breach of a non-delegable statutory duty in the School Act 1979 (BC) but held against the plaintiff: ${ }^{46}$

None of the general duties gives school boards full responsibility for students' welfare while on school premises, in the way that the statutes in Lewis gave the Ministry full responsibility for overseeing maintenance projects and for ensuring that workers exercised reasonable care. Consequently, the Act does not appear to impose a general non-delegable duty upon school boards to ensure that children are kept safe while on school premises, such as would render the Board liable for abuse of a child by an employee on school premises.

$E D G$ can be distinguished from $S v$ Attorney-General because it involved a school board while $S$ was concerned with children who had been taken into care by the Crown and placed with foster parents. However, the reasoning in EDG is arguably inconsistent with Lewis, in which a non-delegable duty was recognised not because of the scope of the statutory duty (which was very general ${ }^{47}$ ) but because of the relationship between the statutory authority and the plaintiff. Where the defendant takes a child into care in the exercise of its statutory powers, it arguably puts itself in the same position as the defendant in Lewis, because the plaintiff in both situations is forced to rely on the defendant for protection. In both $K L B$ and $E D G$ the Supreme Court failed to ask the right question: what responsibility did the defendant assume for the child's wellbeing? In $S v$ Attorney-General the New Zealand Court of Appeal arguably reached the right result, although the reasoning is open to criticism.

\footnotetext{
${ }^{45}$ Ibid, at [27].

${ }^{46}$ EDG v Hammer 2003 SCC 52, [2003] 2 SCR 459, at [20].

${ }^{47}$ The relevant duty was in the Ministry of Transportation and Highways Act RSBC 1979 c 280 s 45 :

The minister shall direct the construction, maintenance and repair of all government buildings, highways and public works in progress, or constructed or maintained at the expense of the Province, and which are under his control.
}

See the discussion in Stevens, above n 3, at 349. 
4 Extending the sui generis agency test

Since $S$ v Attorney-General in 2003, New Zealand courts have refused to expand vicarious liability further, perhaps because the reasoning in $S v$ Attorney-General is difficult to apply. In $S$ the relationship between the Crown and foster parents was classed as an "unusual, indeed unique" class of agency, but the Court gave no hints as to how far the unique class was intended to stretch. If $S$ is analysed as a nondelegable duty, the question becomes whether the defendant has assumed responsibility for the child's welfare, and the scope of the liability is dependent on the breadth of the responsibility assumed. This test is arguably easier to apply than the vague "sui generis agency" test.

For example, in White, Miller $\mathrm{J}$ refused to extend the rule in $S$ to include the relationship between the Crown and the children's biological parents. ${ }^{48}$ The children had been made state wards by court order but had been returned to their parents. Miller J observed that: ${ }^{49}$

... they were not appointed in the sense that they were selected by the DirectorGeneral from a pool of available foster parents. Rather, Mrs White was the plaintiffs' mother and there were no viable alternatives to placing them in her care.

Miller J applied the agency test in $S$, asking whether "the plaintiffs or the wider community would consider that Mrs White and Mr Vincent were acting on [the Director-General's] behalf." The question may have been answered differently if Miller J had focused on whether the Directory-General had assumed responsibility for the children's safety.

\section{G Summary}

If the child abuse cases were truly vicarious in the orthodox non-fault sense a vindicatory approach would be inappropriate: it would force the defendant to vindicate a wrong which it did not commit. However, the better analysis of the cases is that the defendants are under non-delegable duties. Therefore vindicatory damages may be appropriate in order to vindicate the breach of the defendant's duty, emphasising the relationship between the defendant and plaintiff, which would not necessarily be present if liability were truly vicarious.

If the non-delegable duty analysis is not accepted, then it should be acknowledged that there are now two types of vicarious liability. Where the traditional "no-fault"

\footnotetext{
${ }^{48}$ White $v$ Attorney-General HC Wellington CIV-1999-485-85, CIV-2001-485-864, 28 November 2008. The Court of Appeal did not decide the issue: White v Attorney-General [2010] NZCA 139. ${ }^{49}$ Ibid, at [373]. The Supreme Court refused leave to appeal: Wv Attorney-General [2010] NZSC 69, (2010) 19 PRNZ 921.
} 


\section{Chapter VI Vicarious Liability}

vicarious liability is imposed, non-loss based damages are inappropriate. However, where the modern kind of vicarious liability is imposed, as in Lister, Bazley and S, vindicatory damages should be available to mark the breach of the defendant's duty to the plaintiff. 


\section{The Omissions Rule}

In chapter six the focus was on cases where public authorities are held vicariously liable for the wrongs of their employees or other third parties who commit torts, for example foster parents. This chapter and the one that follows are concerned with direct liability, where the public authority is held liable for its own negligence. ${ }^{1}$ The emphasis is much more focused on liability rather than on damages, but the vindicatory approach is used to help explain the developments of the negligence rules in the child welfare cases in both England and New Zealand.

The type of case analysed in this chapter and in chapter eight typically concerns a public authority which, it is alleged, failed to exercise its statutory power to protect the plaintiff from a third party. The third party may be a stranger to the authority. For example, New Zealand's Child Youth and Family Services (CYFS) might receive a complaint that a child is being abused by his or her parents. CYFS may have never met the parents or the child, but through its negligence in dealing with the complaint, it may fail to exercise a statutory power to investigate and the child may therefore continue to suffer abuse which CYFS could have prevented. ${ }^{2}$

Tipping $\mathrm{J}$ in Couch identified three issues which often arise when there is an allegation of a failure to exercise a statutory power to protect the plaintiff from third party abuse: ${ }^{3}$

The law has traditionally been cautious about imposing a duty of care in cases of omission as opposed to commission; in cases where a public authority is performing a role for the benefit of the community as a whole; and in cases where it is the actions of a third party rather than those of the defendant that are the immediate cause of the loss or harm suffered by the plaintiff.

The first issue, whether liability can be imposed for omissions, is the subject of this chapter. The second issue (whether statutory powers are imposed for the public benefit and therefore cannot sound in private law damages) is dealt with in the following chapter. The third issue which Tipping $\mathrm{J}$ mentions is not given separate treatment because it is the subject of the entire thesis; it underpins the discussion of all the other issues.

\footnotetext{
${ }^{1}$ For discussion of whether the Crown can be sued directly in negligence, see chapter two, at the text to footnote 4 .

${ }^{2}$ This set of facts is similar to $X v$ Bedfordshire [1995] 2 AC 663 (HL).

${ }^{3}$ Couch v Attorney-General (on appeal from Hobson v Attorney-General) [2008] 3 NZSC 45; [2008] 3 NZLR 725 at [80].
} 


\section{A The Equality Principle}

The first two problems identified by Tipping $J$ relate to an important concept in the common law called the equality principle. This principle is that the Crown should be subject to the same law as private individuals. Therefore, if private individuals are not liable for omissions (the first issue identified by Tipping J), it follows that public authorities should not be liable for omissions either. This rule, which is usually associated with Dicey, ${ }^{4}$ was explained more recently in the following way by the High Court of Australia in $2009:^{5}$

... the claim that the [defendants] were repositories of a statutory power and that the scope of the asserted duty of care related to the discretion whether or not to exercise that power does not place the case into a distinct field of actionable tort.

Therefore the executive is subject to all the same liabilities as private individuals, but no more. ${ }^{6}$ In the following two chapters it is argued that the equality principle has been overtaken by the developments in negligence in the child abuse cases. The equality principle cannot explain the results in Prince and $D v$ East Berkshire. The rejection of the principle can be explained as a necessary prerequisite to vindicating the underlying community duty to protect children.

\section{B The General Rule against Omissions}

In the common law defendants are not usually liable for omissions. Jane Stapleton describes the difference between doing something and failing to do something as the only truly fundamental principle in negligence: ${ }^{7}$

In negligence only two ... concerns are trumps: the one underlying the rule that I am liable if I carelessly bump a stranger into a pool; and the one underlying the rule that I am not liable if I fail to try to rescue a stranger drowning in a pool.

Failing to do something is usually described as an omission or non-feasance. In the child abuse cases the allegation is often that the defendant failed to confer a benefit. In the classic example of failing to rescue a drowning child, the stranger faces no liability unless he or she falls into one of a number of exceptions, usually based on a special relationship with the child (for example a parent or caregiver).

\footnotetext{
${ }^{4}$ Albert V Dicey Introduction to the Study of the Law of the Constitution (8th ed, Macmillan, 1915) at 114.

${ }^{5}$ Stuart v Kirkland-Veenstra (2009) 237 CLR 215 (HC) at 48; see also Elias CJ and Anderson J in Couch (No 1) above n 3 at [55].

${ }^{6}$ Peter W Hogg and Patrick J Monahan in Liability of the Crown (3ed, Carswell, Scarbourgh, 2000) argue that this rule continues to provide a satisfactory explanation of state liability.

${ }^{7}$ Jane Stapleton "The golden thread at the heart of tort law: Protection of the vulnerable" (2003) 24 ABR 1, at 5.
} 


\section{The Difficulty of Distinguishing between an Act and an Omission}

The difference between an act or omission is not always easy to identify. The difficulty can be seen in the New Zealand Court of Appeal decisions in Prince ${ }^{8}$ and $B$ $v$ Attorney-General. ${ }^{9}$ In Prince, the Department of Social Welfare ${ }^{10}$ had received a complaint that the plaintiff was neglected. It was alleged that they had negligently failed to investigate the complaint. The Court of Appeal rejected any suggestion that the claim could be struck out because it alleged a pure omission: ${ }^{11}$

... in terms of the pleadings the case cannot be characterised as one of total failure to consider the alleged complaint - the allegation is of failure to investigate the complaint "adequately or at all". There is no basis for determining striking out on the footing that it is necessarily a pure omission case ... It cannot be predicated that the department made any particular decision in relation to the complaint ...

Richardson P's analysis highlights the difficulty of distinguishing between an omission and an act when an authority has received a complaint. They must do something with the complaint itself, and even if they decide to do nothing the decision-making process itself could conceivably be described as an act. Realistically though it is hard to see how the allegation could be described as anything other than an omission: the plaintiff complained that the Department had passively received a complaint without doing anything about it.

Tipping J, a member of the Court of Appeal in both Prince and $B$, acknowledged the artificiality of this analysis in the latter case: ${ }^{12}$

In Prince, the central allegation was that the department, negligently and in breach of its duty of care, had failed to make any, or any adequate, investigation of a complaint about the way Mr Prince was being looked after by his parents. The central allegation in the statement of claim was short and simple - "DSW did nothing". The case must be read in that light.

Therefore Prince should be analysed as an exception to the general rule against omissions unless there is a pre-existing relationship. As argued below, the rationales underpinning the omissions rule do not have much relevance to cases like Prince where the defendant is the state or a local council. Where the defendant is a statutory authority specifically created to prevent child abuse in fulfilment of the obligations of

\footnotetext{
${ }^{8}$ Attorney-General v Prince and Gardner [1998] 1 NZLR 262 (CA)

${ }^{9}$ B v Attorney-General [2004] 3 NZLR 145 (PC).

${ }^{10}$ The precursor to Child Youth and Family Services, see chapter three, text to footnote 4.

${ }^{11}$ Prince, above $\mathrm{n} 8$, at 281.

${ }^{12}$ B v Attorney-General [1999] 2 NZLR 296 (CA) at 307
} 
the community which it represents, its failures may sometimes need to be vindicated whether they are acts or omissions.

\section{Exceptions to the General Rule}

The courts have always recognised exceptions to the general rule against affirmative duties. These have traditionally been explained by a pre-existing relationship, usually based on an assumption of responsibility, as Pollock wrote: ${ }^{13}$

Some already existing relation of duty must be established, which relation will be found in most cases, though not in all, to depend on a foregoing voluntary act of the party held liable. He was not in the first instance bound to do anything at all; but by some independent motion of his own he has given hostages, so to speak, to the law. Thus I am not compelled to be a parent; but if I am one, I must maintain my children.

This was the rationale of the 1966 New Zealand Court of Appeal decision in McCallion $v$ Dodd, in which a two-parent two-child family were walking along the road and the mother and one of the children were struck down by a vehicle. ${ }^{14}$ The Court of Appeal held that the father had a duty in that case even though he was carrying the other child, and the son who was struck down was holding the mother's hand. The mother's deafness convinced the Court that the father retained a duty to take care of the child on the road. The majority held that the parents owed an affirmative duty to protect the child because there was a pre-existing relationship based on assumption of responsibility: “[T] he true basis of [the father's] duty lies in the assumption by the parent of the responsibility on the occasion. That assumption is the foundation of the liability."15

In some of the public authority liability cases for child abuse there is a pre-existing relationship available on which an affirmative duty can be based. For example in the English case Barrett the plaintiff had been removed from his parents shortly after his birth and placed in the care of various foster parents and state-owned care facilities. ${ }^{16}$ He alleged that negligence on the part of the state had ruined his life in various ways. The House of Lords refused to strike out the pleadings, recognising that there might be an affirmative duty of care. The defendant had taken the child into its care, so it is possible to reconcile the alleged affirmative duty with the omissions rule because it fits within the exception based on assumption of responsibility. However, in Prince there was no such pre-existing relationship.

\footnotetext{
${ }^{13}$ Sir Frederick Pollock The Law of Torts: A treatise on the principles of obligations arising from civil wrongs in the common law (13th ed, London, Stevens \& Sons Ltd, 1929) at 415.

${ }^{14}$ McCallion v Dodd and Another [1966] NZLR 710 (CA).

${ }^{15}$ Ibid, at 729, per McCarthy J; Turner J cited Hedley Byrne and Co Ltd $v$ Heller and Partners Ltd. [1964] AC 463 (HL).

${ }^{16}$ Barrett v Enfield London Borough Council [2001] 2 AC 550 (HL).
} 
Other situations in which liability for omissions have been imposed were considered by Lord Goff in Smith v Littlewoods. ${ }^{17}$ The defendants owned a cinema adjacent to the plaintiffs' property. Vandals broke in and started a fire which damaged the plaintiffs' buildings. While the House of Lords was unanimous in dismissing the cause of action only Lord Goff based his decision on the rationale that the common law does not impose liability for failure to prevent harm. ${ }^{18}$ He held that there was no general principle that liability for omissions could be imposed, even where there is foreseeability. ${ }^{19}$ Based on this starting point, he identified a number of categories in which the judges had made exceptions and allowed liability for omissions. While he was in the minority in his approach, his speech has become an important authority for the omissions rule and its exceptions. ${ }^{20}$

The categories identified by Lord Goff included: assumption of responsibility, vicarious liability, where the defendant is an occupier, where there is a special relationship between the defendant and the third party based on control, and where the defendant "negligently causes or permits to be created a source of danger". 21 There are dicta in Lord Goff's speech that suggests that liability can be imposed merely on the basis that the authority knew of the danger, which could be analogised with child welfare cases where the defendant knew that the child was in danger of being abused even though there was no pre-existing relationship. ${ }^{22}$ However, these passages seem to be restricted to situations in which the source of danger is on the defendant's land. Ultimately it is difficult to glean from any of Lord Goff's categories, or those suggested in the textbooks, any support for an affirmative duty to protect children from third party harm. This reflects, in part, the difficulty of imposing a duty on a relationship that arises only because of statute, when the common law is based on a refusal to recognise separate public authority duties of care which are not identical to those owed by private individuals.

\footnotetext{
${ }^{17}$ Smith v Littlewoods Organisation Ltd [1987] AC 241 (HL).

${ }^{18}$ Cf Lord MacKay's speech, ibid at 261, applying a general rule of reasonable foreseeability of harm. See also Lord Brandon of Oakbrookat at 250. The difference in reasoning may be attributable to the fact that the case was an appeal from Scotland, where the distinction between acts and omissions is not applied in the same way as in England: Elspeth Reid "Smith v Littlewoods Organisation Ltd (1985)" in Charles Mitchell and Paul Mitchell (eds) Landmark Cases in the Law of Tort (Hart Publishing, Oxford, 2010) 251.

${ }^{19}$ Smith v Littlewoods, above n 17, at 272.

${ }^{20}$ It is endorsed by the leading textbooks in this area, see for example Michael A Jones (ed) Clerk \& Lindsell on Torts (20th ed, Sweet \& Maxwell, London, 2010) at 446; Christopher Walton (ed)

Charlesworth \& Percy on Negligence (London, Thomas Reuters, 2010) at 44.

${ }^{21}$ Smith v Littlewoods, above n 19, at 272

${ }^{22}$ Ibid, at 274 and 275.
} 


\section{E The Rationales Underpinning the Rule}

There are two main rationales underpinning the omissions rule which are presented in the case law. First, this rule has been identified with the common law's promotion of individual autonomy. ${ }^{23}$ A more recent justification is concerned with efficiency. It is said that imposing liability for omissions does not lead to an efficient allocation of resources. Both of these justifications were identified by Lord Hoffmann in Stovin $v$ Wise: $:^{24}$

One can put the matter in political, moral or economic terms. In political terms it is less of an invasion of an individual's freedom for the law to require him to consider the safety of others in his actions than to impose upon him a duty to rescue or protect ... In economic terms, the efficient allocation of resources usually requires an activity should bear its own costs. If it benefits from being able to impose some of its costs on other people (what economists call 'externalities,') the market is distorted because the activity appears cheaper than it really is. So liability to pay compensation for loss caused by negligent conduct acts as a deterrent against increasing the cost of the activity to the community and reduces externalities. But there is no similar justification for requiring a person who is not doing anything to spend money on behalf of someone else.

Both rationales fit awkwardly when applied to cases like Prince and East Berkshire. The concern in these cases is not so much shifting loss between parties (much of this is already done through social assistance programmes ${ }^{25}$ ) but about vindicating rights, and therefore questions about efficiency are unhelpful. Nor are concerns about autonomy useful: public authorities are representative of the community, and lack an interest in their own autonomy. The equality principle presents difficulties in these cases because the interests of public and private defendants do not equate.

\section{F The Autonomy Rationale}

One rationale for the rule against affirmative duties is based on a recognition that there can be no right to protection from strangers, because it restricts the stranger's right to autonomy. Stevens has written in defence of a rights-based theory in which tort law is conceptualised as a way of providing compensation whenever the defendant interferes with the plaintiff's rights. Under this approach the judges should develop the law to strike a balance between the rights of the plaintiff and the

\footnotetext{
${ }^{23}$ Todd, Stephen (ed) The Law of Torts in New Zealand (5th ed, Brookers, Wellington, 2009) at 164; Clerk \& Lindsell on Torts, above n 20, at 447.

${ }^{24}$ Stovin v Wise [1996] AC 923 (HL) at 943.

${ }^{25}$ Discussed in chapter two.
} 
defendant. The plaintiff's rights are limited by the defendant's right to live as he chooses, to live autonomously. Stevens describes it this way: ${ }^{26}$

The claim rights which we have which are good against the rest of the world are of a negative kind. I can exclude you from my property, you may not touch me without consent, and you may not harm my reputation. I cannot compel you to repair my car, cure my illness, or speak well of me. All of us have a liberty to choose to behave as we please, so long as we do not infringe the rights of others. We do not have rights good against the rest of the world to compel others to come to our assistance. A modern day priest and Levite would not infringe any rights of the man stripped of his raiment when they walk on by on the other side.

The starting position of the common law is based upon a premium placed upon our freedom to choose how we live our lives ... the failure to confer a benefit upon someone else does not, alone, constitute the infringement of a right.

The reason, according to Stevens, that the common law does not protect rights to have benefits conferred is, under this rights-based approach, that the defendant should be free to choose how to live his or her life. This interest of the defendant's reflects an emphasis in the common law on autonomy. ${ }^{27}$

Beever has also presented a theory of tort law which would exclude liability for omissions. ${ }^{28}$ Both Beever and Stevens argue that liability cannot be imposed unless the defendant violates the rights of the plaintiff or fails to confer a benefit for which he or she has voluntarily assumed responsibility. However, they frame the argument slightly differently. Stevens starts with the defendant's autonomy and then argues that this must be protected by not imposing affirmative duties on people unless they voluntarily assume responsibility. Beever's starting point is the relationship between the plaintiff and defendant: ${ }^{29}$

In determining wrongdoing, then, the focus is on the personal interaction between the wrongdoer and the wrong-sufferer. The focus is not on the consequences of the wrongdoer's action for society as a whole. The injustice committed by the wrongdoer is an instance of personal wrongdoing and the injustice suffered by the wrong-sufferer has a claim in corrective justice only if the wrongdoer violated her right, and she can claim from the wrongdoer only if her right was violated by that particular wrongdoer.

\footnotetext{
${ }^{26}$ Robert Stevens Torts and Rights (Oxford University Press, Oxford, 2007) at 9.

${ }^{27}$ Cf Stuart $v$ Kirkland-Veenstra, above n 5, where the plaintiff's autonomy is used as a justification for refusing to recognise a duty of care to protect him from self-harm.

${ }^{28}$ Allan Beever Rediscovering the Law of Negligence (Hart Publishing, Oxford, 2007) although he prefers to call this non-feasance.

${ }^{29}$ Ibid at 45 , emphasis in original.
} 
Beever argues that where the defendant violates the plaintiff's rights, for instance by abusing the child, there is a personal interaction in which one person violates the rights of another, which corrective justice requires to be corrected. There is also a violation of a right if one person assumes a responsibility to another and then fails to fulfil that obligation. However, where a stranger fails to rescue a drowning child, there is no relationship or personal interaction to trigger liability: ${ }^{30}$

Because the child did not fall into the water because of any wrongdoing of mine, there is no justification in corrective justice to hold that I now owe him an obligation to rescue him.

A duty would not be required "to correct anything [the stranger] had done to the child." "31 The end point for both Stevens and Beever is the independence of the defendant, although Stevens emphasises the defendant's right to autonomy, while Beever focuses more on the fact that the defendant has had no personal interaction with the plaintiff.

In the context of public authority liability, there are two main difficulties with a rationale that relies on the defendant's autonomy. First, it is that it is not clear that public authorities have any. As Fleming has pointed out: ${ }^{32}$

From a policy point of view, it is arguable that the sacrifice of individual liberty, implicit in affirmative duties on private individuals, has no counterpart in the case of public authorities specifically entrusted with powers and resources for the sake of public health and safety.

While it might be important to protect the freedom of private individuals to choose whether or not to rescue, reflecting an emphasis on the capacity for self-reflection and choice, public authorities are created to represent the public, not to choose whether or not to engage in altruistic behaviour. If the voting public have chosen (loosely speaking) to entrust an authority with power to protect children, it is difficult to conclude that there should be much autonomous freedom left to the authority to decide whether or not to protect children in danger of abuse or neglect.

In the 2008 New Zealand Supreme Court decision Couch, Elias CJ made a similar argument. $^{33}$ The majority refused to strike out the allegation that the Crown through the parole board had negligently placed Bell in employment in the plaintiff's work place, holding that there could be a duty of care if the plaintiff was part of a group that

\footnotetext{
${ }^{30}$ Ibid at 221 .

${ }^{31}$ Ibid at 221emphasis added.

32 John G Fleming The Law of Torts (Sweet \& Maxwell Ltd, 1992, 8th ed, London) at 158. The passage does not appear in the ninth edition.

${ }^{33}$ Couch, above n 3.
} 
was at "special risk". ${ }^{4}$ Elias CJ delivered the reasons for herself and Anderson J, also refusing to strike out the proceedings but dissenting in approach. She observed that the Probation Services could not be treated like other, non-public defendants, because it lacked the freedom to choose whether or not to exercise its power to control probationees: $:^{35}$

... the Probation Service could not be a bystander. It was obliged to undertake the supervision which was its statutory duty. It had no discretion whether or not to supervise.

Elias CJ and Anderson $\mathrm{J}$ held that if defendants were liable for failing to confer a benefit when they had assumed a responsibility to do so, public authorities should be liable if a statute had imposed responsibility upon them: ${ }^{36}$

If voluntary assumption of responsibility can give rise to sufficient proximity, it would seem odd if statutory imposition of responsibility is wholly irrelevant to the judgment whether there is a duty of care. We do not think it can be.

The second problem with the Stevens' and Beever's models is that they only make sense of tort law as long as it is thought of as solely private law. Beever explicitly eschews any notion of community obligation: "In corrective justice ... the focus is on the relationship between the parties rather than on the parties as solitary individuals or as members of a wider community." 37 As long as public authorities act in ways similar to those of private individuals, this theory of tort law presents no problem. For example, some of the child welfare cases can be explained by a pre-existing relationship, as when the authority takes children into care and places them in institutions which it operates.

The difficulty is where tort law is used in a more obviously public law way, as where the complaint is that the authority failed to exercise a statutory power to protect a victim of child abuse (the allegation in Prince and East Berkshire). As Beever acknowledges, this is inconsistent with his theory. However, Beever is too quick to discount the importance in tort law of the defendant's relationship with the wider community. When the defendant is a public authority like Child Youth and Family Services (or the Probation Services) it is unrealistic to treat them like private individuals and to ignore the community obligations. In the child welfare cases against the Crown, the defendant is representative of the community and its wrongs are breaches of the community's obligations to the plaintiff. As the New Zealand

\footnotetext{
${ }^{34}$ Ibid, at [112].

${ }^{35}$ Couch, above n 3, at [58].

${ }^{36} \mathrm{Ibid}$, at [62]

${ }^{37}$ Allan Beever, above n 28, at 46.
} 
Court of Appeal said in $S$, without liability, "the community obligation will not be recognised." 38

The idea that tort law is only private law is shared by Lord Hoffmann. His writing is based on a view that contrasts public law with tort law. On this approach, the equality principle is a logical corollary of the view that tort law is private law, because public authorities are only liable when a private defendant in the same position would be liable: ${ }^{39}$

... public bodies owe no duty of care by virtue only of the fact that they have statutory powers or public law duties. An actual relationship with the claimant, such as would give rise to a duty of care on the part of a private body, is required.

Lord Hoffmann delivered the majority judgment in Stovin $v$ Wise, in which he relied on the omissions rule in holding that the defendant highway authority was not liable for the way it exercised its statutory powers. ${ }^{40}$ In Stovin $v$ Wise, the defendant highway authority had decided to do something about a dangerous intersection. There was a tall bank which prevented drivers moving into the traffic from seeing other cars. There was correspondence with British Rail, who owned the land on which the bank stood, but the matter was not pursued. An accident occurred, and the defendant joined the authority as a third party, alleging that it had negligently failed to exercise its statutory power.

While Lord Hoffmann ensured that the defendant authority was treated the same way as any private individual would be in tort law, Lord Nicholls in the minority was less concerned with bright lines between public and private law but more with ensuring that victims of accidents were not left without a remedy. Lord Nicholls' preparedness to extend tort law to compensate accident victims recognises the special position of public authorities, who may be able to prevent the plaintiff's loss because of powers which private defendants do not have. However, such an approach is arguably inappropriate in cases where the conventional heads of loss are already partly remedied through social assistance programmes or compulsory insurance schemes (as with traffic accidents). As Carol Harlow has argued, imposing liability where insurance is ubiquitous opens "the 'deep coffers' of the state to financial marauders, primarily private insurers, sharks lurking unseen in the deep waters

\footnotetext{
${ }^{38} S$ v Attorney-General [2003] 3 NZLR 450 (CA) at [70].

${ }^{39}$ Lord Hoffmann "Reforming the Law of Public Authority Negligence" (2009) The Bar Council $<$ www.barcouncil.org.uk>, at [15]; see also Carol Harlow State Liability: Tort Law and Beyond (Oxford University Press, 2004, Oxford) at 32-33 for a discussion of Lord Hoffmann's approach to the public and private law divide.

${ }^{40}$ Stovin, above n 17.
} 
beneath tort actions". ${ }^{41}$ Even where the loss is already compensated in this way, however, it might be necessary to vindicate the wrong through a non-loss based remedy in order to recognise the defendant's failure to prevent the harm despite its special statutory powers bestowed for this specific purpose.

\section{G The Loss Distribution Rationale and Cost-benefit Analyses}

As Lord Hoffmann acknowledged, autonomy is not the only rationale for the immunity from liability for omissions. ${ }^{42}$ An alternative rationale is that imposing liability for a failure to act does not incentivise an efficient allocation of resources. Lord Nicholls in the minority discussed the efficiency rationale of the omissions rule in the following passage: ${ }^{43}$

Liability for omissions gives rise to a problem not present with liability for careless acts. He who wishes to act must act carefully or not at all. A producer of ginger beer must adopt a safe manufacturing process. If this would be uneconomic, he ought not to carry on the business. With liability for omissions, however, a person is not offered a choice. The law compels him to act when left to himself he might do nothing.

Lord Nicholls' description of the economics rationale blurs into the more traditional justification discussed above concerning the defendant's autonomy. If a duty to act is imposed, the defendant has no opportunity to carry out a cost benefit analysis whether the enterprise costs more than the profit obtained (with public bodies there is no profit, of course, but there is a lost opportunity to do other things with the money). The focus remains on the defendant's capacity to choose, glossed over with words such as "uneconomic" and "externalities". 44

Lord Nicholls dictum is not necessarily an accurate description of his own approach, however. His speech read as a whole suggests that rather than adopting an "invisible hand" approach in which it is assumed that rationale agents will reach efficient outcomes if they are forced by tort law to absorb their costs, judges should ask the bigger question whether imposing liability leads to an appropriate allocation of loss: "Leaving the loss to lie where it falls is not always an acceptable outcome." 45 However, a loss distribution approach to tort law assumes that there is a loss to begin with, and in Stovin there was compulsory third party insurance for drivers of vehicles to compensate the loss. ${ }^{46}$ A hand out from the highway authority was unnecessary. A

\footnotetext{
${ }^{41}$ Ibid, at 22, citing T Weir " Governmental Liability" [1989] PL 40.

${ }^{42}$ Stovin $v$ Wise, above $\mathrm{n} 24$, at 945.

${ }^{43}$ Ibid, at 933, emphasis added.

${ }^{44}$ Ibid, at 933 and 944.

${ }^{45}$ Ibid, at 933.

${ }^{46}$ Ibid, at 958, although Nicholls discussed this too, as noted by Harlow, above n 39, at 40.
} 
similar difficulty arises with the child welfare cases, in which much of the loss claimed is already covered, and dealt with better, under social welfare.

Lord Nicholls may also have been influenced by a deterrent purpose in tort law: imposing liability may encourage the authority to do its job better. ${ }^{47}$ In $S v$ AttorneyGeneral Blanchard J anticipated that imposing vicarious liability on the Crown for child abuse by foster parents: ${ }^{48}$

... may provide an incentive for the State to take even greater precautions in the future for the protection of children in its care by way of vetting and monitoring of foster parents.

Whether tort law is effective as a deterrent is another thesis in itself. However, as McLay has pointed out, child abuse cases are usually concerned with historic events, and the present practices of the defendant will most likely have changed by the time litigation is brought: "To defend such claims, it [is] necessary to go to rest homes rather than to the department to obtain evidence. ${ }^{49}$

Law and economics scholars have asked whether imposing liability for omissions will encourage people to confer benefits. Landes and Posner, in their article on this subject, begin with the assumption that rescuing drowning people should be encouraged, and then create a utility function which they differentiate to decide whether rescuers under a legal duty to rescue if they are near an accident will do so in order to maximise their utility. ${ }^{50}$ Such an approach is beyond the scope of this thesis, but it may be questioned whether it applies very well to public authorities. Some considerations, such as Landes' and Posner's concern that if liability is imposed for failure to rescue people will avoid places where accidents are likely, is probably not a relevant factor for authorities who cannot easily remove themselves from the sector.

Lord Hoffmann has extra-judicially made calls for a different kind of cost-benefit analysis, in which the cost of imposing an affirmative duty on public authorities and the consequent litigation are balanced against the lost opportunity to spend the money on other public goods. In a speech to the United Kingdom Bar Council, he described how he spoke to the Chief Educational Psychologist of Leicestershire County Council

\footnotetext{
${ }^{47}$ Carol Harlow, above n 39, at 40-41.

${ }^{48} \mathrm{~S} v$ Attorney-General, above n 38, at [71].

${ }^{49}$ Geoff McLay 'Remedies for Breaches of 'Public' Obligation: The Equality Principle Meets the Welfare State and the New Constitutionalism" in Jeff Berryman and Rick Bigwood The Law of Remedies: New Directions in the Common Law (Irwin Law, 2010, Toronto) at 406.

${ }^{50}$ William M Landes and Richard A Posner "Salvors, Finders, Good Samaritans, and Other Rescuers: An Economic Study of Law and Altruism" (1978) 7 LJS 83.
} 
about the effect of the House of Lords' decision in Phelps. ${ }^{51}$ In that case, it was held that an authority's educational psychologists owed duties of care to children whom they interviewed, and that breach of these duties could lead to damages for vicarious liability. After the decision the Leicestershire Council was faced with 58 claims, all of which were resisted. Two went to court, although one was abandoned at the door of the courtroom and the other collapsed during trial. "At considerable expense, the LEAs succeeded in defending themselves." 52 One of the main difficulties was causation: ${ }^{53}$

There are ... problems of causation: whether the child's problems were caused by dyslexia rather than disruptive behaviour; what kind of treatment would have been possible within the options open to a school with many other children to teach and finally, whether it would have made any difference to the child's subsequent life. It is almost impossible to prove on a balance of probability that if the child had received a different form of teaching, he would have become a model and prosperous citizen instead of the drug-addicted petty criminal whom the judge sees in the witness box.

Part of the "cost" in such an analysis is the wasted litigation because of the difficulty in proving causation. The child welfare cases are no different from the education cases in this respect: even where the plaintiff is able to show breach of duty, the courts find themselves in severe difficulties trying to apportion the "damage" suffered by the plaintiff (which usually includes problems such as alcohol abuse, broken relationships and patchy employment history) and having to deduct social assistance payments. ${ }^{54}$ The better approach as advanced in this thesis is to award non-loss based damages which vindicate the breach of the duty, rather than attempting to compensate some kind of fictional "loss". If this approach is adopted, the cost of litigation is not "wasted": it serves a usesful purpose in marking the underlying wrong that the state failed to protect the plaintiff, and establishing (through discovery) how this occurred.

The application of the omissions rule in the highway cases and its absence in the child welfare cases may reflect a sense that in the latter cases compensation through social welfare is perhaps insufficient to mark the wrong. Where the wrong is a traffic accident, the focus is on the amount of loss and who should pay for it. The omissions rule leads to an acceptable result because the loss is paid for by insurance companies. The child welfare cases, however, engage questions of community responsibility and the relationship between the state and individuals. Loss is not the sole concern. In

\footnotetext{
${ }^{51}$ Lord Hoffmann, above n 39 at [25] ff. Phelps v Hillingdon London Borough Council [2001] 2 AC 619.

${ }^{52}$ Ibid at [26].

${ }^{53}$ Ibid at [28].

${ }^{54}$ As discussed in chapter three.
} 
order to vindicate the wrong, the courts have ignored the equality principle, which would have led to an unacceptable result.

\section{H Does the End Justify the Means?}

The two main rationales for the omissions rule are autonomy and efficiency. Neither of these applies when the defendant is a public authority. However, there is one justification of the omissions rule which explicitly recognises that public authorities are not like private defendants. This rationale is based not on a distinction between acts and failures to confer benefits, but on the way the rule indirectly furthers other purposes of tort liability. For example, Booth and Squires have argued that the omissions rule could be used to protect the state from limitless liability. ${ }^{55}$ In some situations, the number of people who could potentially be protected from harm through an exercise of the defendant's statutory power might be limitless.

The difficulty with such an approach is that the omissions rule is based on a distinction between positive acts and failures to act, not on a distinction between limited and unlimited liability. This concern is easily weighed up as part of the policy or "fair, just and reasonable" stage of the duty of care test, as the Canadian Supreme Court has done in the context of public authority liability in negligence. ${ }^{56}$

\section{Summary}

A rule based on a distinction between positive acts and failures to act is difficult to defend when applied to public authorities. A loss distribution approach may lead judges to impose liability on the Crown if the health care system is perceived as inadequate: ${ }^{57}$ the cost suffered by accident victims is arguably best carried by the broad shoulders of tax payers. ${ }^{58}$ However, where the loss is already insured, or where it is covered by social assistance, a distribution of loss approach becomes redundant. Stevens' and Beever's models of tort law on the other hand, with their emphasis on the defendant's autonomy, struggle with public authorities as defendants, because they are already required by statute to confer benefits. There in no "choice" is the sense captured by an autonomy interest.

The best way to answer the question as to whether liability should be imposed for an omission may be to look at the underlying rights and duties involved. If the cases are concerned with shifting loss, are the victims already compensated in some way, for

\footnotetext{
${ }^{55}$ Cherie Booth QC and Dan Squires The Negligence Liability of Public Authorities (Oxford University Press, Oxford, 2006) at 149.

${ }^{56} R$ v Imperial Tobacco Canada [2011] SCC 42.

${ }^{57}$ Carol Harlow, above n 39, at 21.

${ }^{58}$ John G Fleming The Law of Torts (9th ed, Sweet \& Maxwell, London, 1998) at 210.
} 


\section{Chapter VII The Omissions Rule}

example through insurance or social assistance? Or even if the loss is already compensated, for example under an accident compensation scheme, is there something beyond the loss that needs to be remedied? In the child welfare cases, the underlying community duty is so important that arguably its negligent failure needs to be vindicated through an award of damages beyond the loss suffered. Where the community duty was breached because the defendant failed to exercise a statutory power, this may require courts to ignore the omissions rule and the equality principle. 


\section{Statutory Powers and Duties}

This chapter, like the previous one, considers an issue which commonly arises when establishing a duty of care in negligence against a public authority, and analyses how a vindicatory approach might help to understand the developments in this area. The focus is on whether tort law can be used to vindicate a breach of a statutory duty, or a negligent exercise of a statutory power.

There is a group of scholars and judges in England who have taken a conservative position on this issue. This group, which includes Lord Hoffmann and Nolan, can be identified from the way its members sing the praises of the 1934 case East Suffolk, and therefore their arguments are described in this chapter as the East Suffolk approach. ${ }^{1}$

The East Suffolk approach relies on a bright line distinction between "private" tort law and "public" judicial review. Breaches of statutory duties and the unlawful exercise of statutory power are said to be public law wrongs and are therefore susceptible to judicial review but not to an action in tort, with three exceptions. First, where there is a pre-existing relationship, for example where there has been an assumption of responsibility. Secondly, where the authority negligently exercises its statutory power so that it puts the plaintiff in a worse position than if it had done nothing. The third exception is a separate tort: a statutory duty may give rise to the tort of breach of statutory duty if the courts can infer that Parliament intended the duty to be actionable. If none of these exceptions are established there can be no liability in tort law however because, according to the East Suffolk approach, unless Parliament says otherwise statutory powers and duties are presumed to be enacted for the public benefit, not for the benefit of individuals.

However, there is an alternative approach, which in this chapter is labelled the Anns approach. Scholars like Cornford and judges like Lord Nicholls have favoured the 1978 case Anns in opposition to those who prefer East Suffolk. ${ }^{2}$ Under this less conservative approach, public authorities can be liable in negligence for the way they exercise statutory power, even though there is no Parliamentary intention that the plaintiff should be able to sue, and even though the defendant would not be liable under the orthodox rules of negligence. This chapter argues in favour of the Anns approach.

\footnotetext{
${ }^{1}$ East Suffolk Rivers Catchment Board v Kent [1941] AC 74 (HL). See Lord Hoffmann "Reforming the Law of Public Authority Negligence" (2009) The Bar Council <www.barcouncil.org.uk>; Donal Nolan "The liability of public authorities for failing to confer benefits" (2011) 127 LQR 260.

2 Anns v Merton London Borough [1978] AC 728 (HL). See Tom Cornford Towards a Public Law of Torts (Ashgate, Aldershot, 2008), at 178; Stovin v Wise [1996] AC 923 (HL), at 931 per Lord Nicholls.
} 
Drawing a bright line distinction between statutes in the general public interest and those intended by Parliament to be actionable in damages is simplistic. The child welfare legislation in New Zealand provides a good example of the difficulties experienced under this approach. In the Child, Young Persons and Their Families Act 1989 the Chief Executive is under a duty "to take such positive and prompt action and steps" as will "promote the well-being of children ..." It is not clear that Parliament intended the duty to be actionable in negligence when it is breached, but nor can it be said that the statute is in the public interest to the exclusion of private interests. The long title, for example, provides that the Act is "to advance ... the well-being of children" among other things.

When the duty to protect children is breached, both the general public and the private interests of the child are affected. Similarly, when a statutory power to protect children is exercised negligently (or negligently not exercised at all) and children suffer, both the children and the general public have an interest in seeing the wrong vindicated. The fact that the community has an interest in seeing children taken care of makes it more important, not less important, that children who suffer abuse or neglect through the negligence of those entrusted with statutory power to prevent it are armed with a remedy. As Tipping $J$ said in the New Zealand Bill of Rights Act 1990 (NZBORA) case Taunoa, the general public is also a victim, which suffers alongside the primary victim of the wrong. ${ }^{3}$

\section{A The East Suffolk or Private Law Approach}

Until the House of Lords decision in Anns in 1977 (discussed later) East Suffolk was the leading authority for the proposition that there could be no liability for the way in which a statutory power was exercised, unless one of the three exceptions discussed above was established. ${ }^{4}$ The plaintiffs had a farm that bordered the tidal part of the river Deben. The land was protected by a wall maintained by the defendants. They had the power, under s 34 of the Land Drainage Act 1930, to repair the wall. ${ }^{5}$ The wall broke down in the face of severe flooding, and the Board used insufficient men, with insufficient skill and insufficient materials, taking well over 100 days to repair the wall. In the meantime the river continued to flood the plaintiffs' land.

\footnotetext{
${ }^{3}$ Taunoa v Attorny-General [2007] NZSC 70, [2008] 1 NZLR 429, at [317]. This passage is set out and discussed in chapter 2, at text to footnote 34.

${ }^{4}$ East Suffolk, above n 1. Cf Yetkin v Mahmood [2010] EWCA Civ 776, [2011] QB 827 for a modern application of the rule, although East Suffolk was not cited. For a New Zealand case with similar facts to East Suffolk, see East Agriculture Ltd v Manawatu-Wanganui Regional Council HC Palmerston North CIV-2008-454-31 7 September 2011.

${ }^{5}$ Land Drainage Act 1930 (UK) 20 \& 21 Geo V c 44, s 34:

Every drainage board acting within its district shall have power-
}

(a) To maintain existing works, that is to say, to cleanse, repair or otherwise maintain in a due state of efficiency any existing watercourse or drainage work ... 
The House of Lords held that although a breach of an explicit and mandatory statutory duty might give rise to an action in damages, the negligent exercise of a statutory power was different. The plaintiffs must prove that they suffered more damage than if the defendants had done nothing. For example, where there was a power to light streets, the statutory authority might be liable for causing a fire, but not if they merely failed to light the street and someone injured themselves in the dark. ${ }^{6}$

More important than the reasoning in East Suffolk is the conservative approach the House of Lords took in the case to the development of liability in negligence for the way in which the statutory power was exercised. ${ }^{7}$ In the last twenty years judges like Lord Hoffmann have used East Suffolk as a peg on which to attach their own conception of public authority liability.

The modern East Suffolk approach relies on a very sharp divide between judicial review and tort law. Statutory duties and powers are seen as focused on the general public interest. Therefore the courts should ensure that those entrusted with statutory duties and powers act within the purposes of the legislation. This is done through judicial review, which is focused on the lawfulness of a decision or exercise of power, rather than directly on the relationship between the plaintiff and defendant: ${ }^{8}$

It is manifest in the remedies available to the courts when considering an application, that judicial review focuses on the legality of a decision. The orders challenge the validity of the original decision, rather than seeking to provide for compensation to be paid to an individual.

For example those exercising statutory power must ignore irrelevant considerations in the exercise of their discretion, and they must not exercise it irrationally. Because the statutory duty or power is in the general public interest and the courts will only interfere in order to ensure that the defendant acts lawfully, there is no monetary remedy in judicial review for plaintiffs who suffer loss caused by the unlawful (in the judicial review sense) exercise of a statutory power, unless it is actionable under the "private law" (where there is a nuisance or a breach of contract, for example).

In its project on administrative redress, the English Law Commission asked for responses to its argument that damages should be more widely available for public law wrongs. One of the main criticisms it received was based on this distinction

\footnotetext{
${ }^{6}$ Sheppard v Glossop Corporation [1921] 3 KB 132.

${ }^{7}$ There was one dissent, by Lord Atkin.

${ }^{8}$ Law Commission Administrative Redress: Public Bodies and the Citizen (UKLC R322, 2010) at [2.38], emphasis in original.
} 
between statutes which are in the general public interest, and private law rights in tort: ${ }^{9}$

There were some consultees who disagreed vigorously with the proposal that a wider availability of monetary remedies could or should be introduced in judicial review cases. They opposed the suggestion to allow individuals to claim damages where no private right had been infringed. Such responses drew a sharp distinction between the rights that arise from a public duty, which are owed to the world at large, and private rights that are protected in tort.

The East Suffolk approach was applied in the House of Lords case O'Rourke, in which the claimant alleged that his local council had breached its duty under the Housing Act to provide him with accommodation. Lord Hoffmann, delivering the only speech in the House of Lords, distinguished duties "intended for the protection of a limited class of people" and those which are conferred for the wider public benefit: ${ }^{10}$

Public money is spent on housing the homeless not merely for the private benefit of people who find themselves homeless but on grounds of general public interest: because, for example, proper housing means that people will be less likely to suffer illness, turn to crime or require the attention of other social services.

This approach means that if a public authority fails to confer a benefit (such as an investigation into an allegation of child abuse) when exercising a statutory power, the failure is not actionable because the power is said to be in the general interest. There are three exceptions to the general rule that an exercise of statutory power will not be actionable in negligence even where it is unlawful in the public law sense, and causes loss to the plaintiff. These were mentioned above briefly but are discussed here in more detail.

First, there are times when the authority may bring itself into a relationship with the plaintiff, from which a private law action may arise. ${ }^{11}$ This is because, as mentioned above, it is assumed that statutory power does not exempt authorities from liability in "private law" unless it does so expressly.

Secondly, if the exercise of a statutory power puts the plaintiff in a worse position than he or she would have been if the authority had done nothing, then an action may

\footnotetext{
${ }^{9}$ Ibid, at [2.9], citing "Government, Professor Stevens and Lords Hoffmann" as examples of supporters of this approach.

${ }^{10}$ O'Rourke v Camden London Borough Council [1998] AC 188 (HL), at 193, emphasis added; quoted in Gorringe v Calderdale Metropolitan Council Borough [2004] UKHL 15, [2004] 1 W.L.R. 1057, at [24], per Lord Hoffmann.

${ }^{11}$ O'Rourke, ibid, at 196.
} 
lie for negligence. The East Suffolk case is the best example of this exception: if the defendants had done nothing at all, the land would have been flooded anyway. This is, in some ways, merely an extension of the first exception: it is designed to put defendants with statutory powers in the same position as private individuals, who are also liable if they put the plaintiff in a worse position than if they had done nothing. The rule is more specific to public authorities, however, and it is usually thought of as separate.

Thirdly, there are some statutory duties in which it can be inferred that Parliament intended there to be an action for damages if a breach of the duty caused the plaintiff loss, which will lead to a claim for the tort of breach of statutory duty. The leading authority for this tort in England is $X v$ Bedfordshire, in which the House of Lords struck out allegations that statutory duties to safeguard children and to take them into care could be actionable under the tort of breach of statutory duty. Lord BrowneWilkinson set out the test as follows: ${ }^{12}$

The basic proposition is that in the ordinary case a breach of statutory duty does not, by itself give rise to any private law cause of action. However, a private law cause of action will arise if it can be shown, as a matter of construction of the statute, that the statutory duty was imposed for the protection of a limited class of the public and that Parliament intended to confer on members of that class a private right of action for breach of the duty ... If the statute provides no other remedy for its breach and the Parliamentary intention to protect a limited class is shown, that indicates that there may be a private right of action since otherwise there is no method of securing the protection the statute was intended to confer.

Keith Stanton has described this test as involving a mix of presumptions (the existence of a remedy within the statute and the protection of a limited class of the public) and a general test based on inferred Parliamentary intention. ${ }^{13}$ The breach of statutory duty tort is an exception to the general rule that breaches of statutory duties are not actionable because the duty is in the general interest. It arises only where it can be said that the statutory duty is intended to be in the private as opposed to the public interest, as an exception to the assumption that statutory duties are usually in the public interest.

In $X v$ Bedfordshire, the House of Lords recognised that the statute at issue was intended to confer benefits on a limited class (children), but held that the duties in the statute were too discretionary to establish the tort of breach of statutory duty: ${ }^{14}$

\footnotetext{
${ }^{12} X v$ Bedfordshire County Council [1995] 2 AC 633 (HL). Other parts of the case have been qualified in subsequent decisions, see the discussion in chapter three, text to footnote 38.

${ }^{13}$ Keith, Stanton, and others Statutory Torts (Sweet \& Maxwell, London, 2003) at 25.

${ }^{14} X v$ Bedfordshire, above $\mathrm{n} 12$, at 731.
} 
It is true that the legislation was introduced primarily for the protection of a limited class, namely children at risk ... But in my view those are the only pointers in favour of imputing to Parliament an intention to create a private law cause of action. When one turns to the actual words used in the primary legislation to create the statutory duties relied upon in my judgment they are inconsistent with any intention to create a private law cause of action ... all the statutory provisions [are] made dependent upon the subjective judgment of the local authority. To treat such duties as being more than public law duties is impossible.

Lord Brown-Wilkinson's application of this test emphasises the problem of Lord Hoffmann's approach in O'Rourke: not all statutory duties in which the tort of breach of statutory duty is not established are necessarily in the public interest to the exclusion of a private interest. Child welfare legislation is enacted in the interest of children, yet the legislation does not give rise to an action in breach of statutory duty. Therefore if child welfare legislation does not give rise to an action in negligence, it cannot be for the reason that it is exclusively in the public interest.

In addition to the breach of statutory duty tort where the focus is on implied Parliamentary intention, some statutes expressly provide for damages if the authority fails to confer a benefit upon the plaintiff. ${ }^{15}$

\section{B An Alternative, Public Law Orientated Approach}

This thesis argues that breaches of statutory duties to investigate allegations of child abuse should be actionable in damages, both in negligence and in the separate breach

of statutory duty tort. The vindicatory approach draws on the public interest in having wrongs vindicated as support for recognising an action in damages for the public law wrong. The fact that it is in the general public interest for children not to suffer abuse is given as a reason for recognising a duty sounding in damages. Lord Hoffmann might see it as a reason against imposing a duty. The vindicatory approach is consistent with the approach to damages for breach of NZBORA in which it is said that the public represents a secondary victim who has an interest in seeing the NZBORA duty vindicated. ${ }^{16}$

In his book Towards a Public Law of Torts Cornford has written against the private law approach outlined above, which excludes actionable duties owed to private individuals for breaches of public law which are assumed to be in the public interest: $^{17}$

\footnotetext{
${ }^{15}$ The Highway Act 1980 (UK) discussed below is an example of this.

${ }^{16}$ Taunoa, above n 3, at [317].

${ }^{17}$ Cornford, above n 2, at 17.
} 
... one of the functions of public law is to protect the interest of individuals. This being so, we may think of norms of public law as, in certain circumstances, giving rise to duties to individuals. Such individuals will have, correspondingly, a species of entitlement and breach of the duties owed to them will put public authorities under an obligation to repair the harm that results.

Cornford argues that if a public law wrong (by which he means a decision which can be set aside on an application for judicial review) causes harm to the private interest, then this should be compensated. Otherwise plaintiffs who are able to bring judicial review proceedings are put in a better position than plaintiffs who only discover the public law wrong later when they have already suffered loss and it is too late to retake the decision. The logic could of course be applied either to the availability of a damages award in judicial review proceedings, or to developing tort damages for the negligent exercise or failure to exercise statutory power.

Unlike Cornford, however, this thesis adopts an explicitly vindicatory approach rather than relying on more traditional corrective justice concerns. This thesis does not deal directly with the separate issue whether loss suffered through the negligent exercise of a statutory power should be compensated. The focus is on the narrow issue whether the failure to confer a benefit which would not exist but for the statute should be vindicated even though the statute might be in the general interest. The importance of Cornford's approach for this thesis is his support for the use of damages in tort law to remedy public law wrongs.

Cornford, like others who adopt a flexible approach to imposing liability in negligence for the way a statutory power is exercised, has evinced a preference for the 1977 House of Lords case Anns, as opposed to East Suffolk, discussed above. ${ }^{18}$ The significance of Anns is discussed below. First, however, the approach in New Zealand is analysed.

\section{The New Zealand Approach: an Uneasy Compromise}

The approach in the New Zealand child welfare cases appears to sit mid-way between the conservative approach of Lord Hoffmann and the more radical argument of Cornford. In Prince the alleged duty of care was to exercise a power to investigate any complaints received that a child (such as the plaintiff) was suffering abuse. The Court of Appeal concentrated on a duty in the statute which required the DirectorGeneral to take positive action to prevent child abuse, including where appropriate a prompt inquiry. ${ }^{19}$

\footnotetext{
${ }^{18}$ Ibid, at 178.

${ }^{19}$ See Attorney-General v Prince and Gardner [1998] 1 NZLR 262 (CA) at 279. The relevant part of the legislation is in s 5 of The Children and Young Persons Act 1974:
} 
The cause of action would not arise were it not for the statute: therefore under the private law approach the duty should only be actionable under one of the three exceptions outlined above. However, as emphasised in chapter six, the failure to protect a child from third party danger does not involve an assumption of responsibility, so there is no relationship which would usually give rise to a typical private law cause of action. A pleading of breach of statutory duty was struck out by the High Court and was not appealed. ${ }^{20}$ Nor can it be said that the defendant authority made the situation worse for the plaintiff than if it had done nothing, since the allegation was that the defendant had in fact done nothing. ${ }^{21}$

The Court of Appeal got around this problem by relying on a rule which has since been removed from English law by the House of Lords in Gorringe (discussed below). Where the statutory duty (as opposed to a power) is intended to confer a benefit to an identifiable class, a common law duty of care can be imposed in negligence. However, there must be a statutory duty: a discretionary power is not enough.

Richardson $\mathrm{P}$ thought that the statutory power to arrange for an investigation was a matter of "obligation, not the exercise of discretionary power."22 The statute included words such as "duty" and "shall". However, Henaghan has argued that the statute is more discretionary than the Court was willing to concede. He pointed out that $\mathrm{s} 5$ only provides that the Director-General shall take "positive action and such steps under this Act as in his opinion may assist", which involves discretion on the part of the Director-General. ${ }^{23}$

The approach of the Court was to read down the statutory duty so that it is specific and non-discretionary enough to support a parallel common law duty. The better

Duty of Director-General to undertake preventive work -

(1) It shall be the duty of the Director-General to take positive action and such steps under this Act as in his opinion may assist in preventing children or young persons from being exposed to unnecessary suffering or deprivation or from becoming seriously disturbed or from committing offences.

(2) In pursuance of the duty imposed on him by subsection (1) of this section the Director-General shall arrange -

(a) For prompt inquiry where he knows or has reason to suspect that any child or young person is -

(i) Suffering or likely to suffer from ill-treatment or from inadequate care or control; or

(ii) By reason of his behaviour, causing serious concern to his parents, guardians, or teachers ...

${ }^{20}$ Prince v Attorney-General [1996] 3 NZLR 733 (HC) at 747; Prince (CA), ibid, at 265.

${ }^{21}$ See chapter six, in which it is demonstrated that this case was about an omission.

${ }^{22}$ Prince, above n 19, at 283.

${ }^{23}$ Mark Henaghan "Editorial: Suing for an appalling childhood" (1997) 2 BFLJ 174. 
approach, which would be consistent with Cornford's argument, is to recognise that the duty is a general discretionary duty, but to accept that when this is exercised negligently there a public law wrong which is actionable in private law. This does less mischief to the words of the statute.

Prince concerned the 1974 legislation. The powers under that Act are now set out under the Child, Young Persons and Their Families Act 1989, and plaintiffs alleging negligent failure to exercise powers under that Act may come up against slightly different problems peculiar to that legislation. First, however, the situation of plaintiffs pleading failures to exercise power under the even older, Child Welfare Act 1925 must be considered.

\section{The 1925 Act}

In White, two brothers alleged among other things that the Child Welfare Agency had failed to inquire into the possibility that they were being abused by their father. ${ }^{24}$ In 1966 they were placed under Court-ordered supervision, although they continued to be looked after by their father. Miller $J$ in the High Court held that this put the Agency under a duty of inquiry, which was breached when they failed to speak to the boys alone. The claim failed for other reasons, but the significance of the recognition of a duty of care is that although it could be explained as based upon the assumption of responsibility established by the Court-ordered supervision, Miller J seems to have simply held that the Prince duty applied to the 1925 Act, even though there were no positive duties in the Act, unlike the 1974 legislation. The approach is possibly consistent with Cornford's thesis: the failure to speak to the boys alone was arguably a negligent exercise of statutory power which should be actionable in damages if it causes loss.

\section{The 1989 Act}

The Court of Appeal in Prince also briefly considered the Children, Young Persons, and Their Families Act 1989: ${ }^{25}$

The philosophy and thrust of the 1989 legislation are different. Significantly s 5 of the 1974 Act has been replaced by diffuse and diluted investigation provisions far different from the positive duties under 5 .

The focus of the judges was on the degree of discretion involved in the statutory duty: consistent with the rule discussed above, the approach of the Court was to identify a

\footnotetext{
${ }^{24}$ White v Attorney-General HC Wellington CIV-1999-485-85, CIV-2001-485-864, 28 November 2008; White v Attorney-General [2010] NZCA 139. The Supreme Court refused leave to appeal: $W v$ Attorney-General [2010] NZSC 69, (2010) 19 PRNZ 921.

${ }^{25}$ Prince, above n 19, at 281.
} 
clear statutory duty with not much discretion on which to hang a common law duty sounding in damages. The difference in "philosophy and thrust" between the 1974 and 1989 Acts includes a shift in focus to a greater emphasis on community and family, intended to reflect Maori emphasis on the importance of whanau. ${ }^{26}$

Not everyone has agreed that the duties in the 1989 Act are more diffuse. Henaghan wrote: ${ }^{27}$

This language if anything is more positive than the 1974 Act, and if the majority decision of the Court of Appeal is to be consistent in their reasoning it must also be seen as creating an obligation on the Department [under the 1989 Act].

The difficulty with the Court's observations (which were obiter) is not that the duties in the 1989 are not diffuse (they are) but that this can also be said of the 1974 Act: it is difficult to distinguish the 1989 Act as involving more discretion. The better approach would have been simply to recognise that a discretionary duty is actionable, rather than trying to read down the statutory discretion in the 1974 Act in order to peg a common law duty onto it. It would then be a matter of judgment in each particular case whether the specific statutory duty or power should be actionable.

\section{The Disagreement about Anns and the Private Law Remedy for a Public Law Breach}

The debate concerning public law wrongs outlined above is highlighted by the controversy surrounding two House of Lords cases, East Suffolk (discussed above) and Anns. In the Anns approach, public authorities can be liable for failing to exercise a power or for negligently exercise it, but under the East Suffolk approach they are only liable if they make the situation worse, there is an assumption of responsibility or it can be inferred that Parliament intended breach of the duty to be actionable.

\section{Anns v Merton London Borough}

Anns was the famous font of the building inspection cases: the House of Lords refused to strike out an action alleging that the negligent inspection of a house had led to the plaintiff purchasing a house which breached building regulations. ${ }^{28}$ If the plaintiff could establish at trial that there had been an inspection (an exercise of a power rather than the failure to exercise it) the local council would be liable for any

\footnotetext{
${ }^{26}$ See the discussion of the 1989 Act in Bill Atkin and Geoff McLay "Suing Child Welfare Agencies: A Comparative View from New Zealand"in John Dewar and Stephen Parker (eds) Family Law: processes practices pressures (Hart Publishing, Oxford, 2003) 161, at $175 \mathrm{ff}$.

${ }^{27}$ Henaghan, above $\mathrm{n} 23$, at 175.

${ }^{28}$ Anns, above n 2. This aspect has been overruled in England: Murphy v Brentwood District Council [1991] 1 AC 398(HL). However it is still good law in New Zealand: North Shore City Council v Body Corporate 188529 [2010] NZSC 158, [2011] 2 NZLR 289 [Sunset Terraces].
} 
negligence in the way the inspection had been conducted. ${ }^{29}$ The result was contrary to the East Suffolk rule: if there had been no investigation the plaintiff would have been no better off than if there was a negligent inspection.

In Stovin $v$ Wise, Lord Nicholls in the minority contrasted East Suffolk and Anns in the following way: ${ }^{30}$

Before 1978 the accepted law was that the council could be under no common law liability for failing to act. A simple failure to exercise a statutory power did not give rise to a common law claim for damages: see East Suffolk ... The decision in Anns ... liberated the law from this unacceptable yoke.

This is not strictly accurate. Neither Anns nor East Suffolk concerned the failure to exercise a power, but rather the allegedly negligent exercise of a power. However, Anns and East Suffolk arguably stand for two contrasting ideals beyond their actual ratios. East Suffolk is seen as a clear example of the way tort law does not support actions for breach of a statutory duty or an unlawful exercise of statutory power, with the three exceptions mentioned earlier. Anns stands in contrast as a symbol of the approach in which public law wrongs are actionable in negligence in damages. Cornford, for example, applauds Lord Nicholls in Stovin for keeping "alive the spirit of Anns". ${ }^{31}$

\section{Stovin v Wise and Gorringe}

The approach which East Suffolk is said to stand for was resurrected in two cases, Stovin $v$ Wise and Gorringe, in both of which the defendants were highway authorities. In Stovin, the council had failed to remove a tall bank which prevented drivers moving into the traffic from seeing other cars. ${ }^{32}$ In Gorringe, a driver was speeding around a corner at the crest of a hill when she drove into a bus: she alleged that the highway authority was at fault for not writing the letters SLOW on the approach to the corner. ${ }^{33}$

The cases concerned powers and duties under the Highways Act 1980 (UK). The Act makes the authorities liable to private parties for non-repair of the highways. The Act expressly provides that some of its provisions are actionable by private individuals when breached. This is an example of a statute in which duties are explicitly owed to private individuals as well as to the general public.

\footnotetext{
${ }^{29}$ Anns, ibid, at 760, per Lord Wilberforce, and at 771 per Lord Salmon.

${ }^{30}$ Stovin $v$ Wise, above $\mathrm{n} 2$, at 931.

${ }^{31}$ Cornford, above n 2, at 178.

${ }^{32}$ Stovin, above n 2.

${ }^{33}$ Gorringe, above n 10.
} 
However, the omissions in Stovin and Gorringe were not failures to repair. ${ }^{34}$ Therefore in Stovin it was alleged that the defendant had failed to exercise its power to serve a notice on the owner of the land on which the bank stood. ${ }^{35}$ The majority held that the authority could only be liable if they made the road more dangerous by exercising the power than if it had done nothing, for instance by leaving debris behind on the road, creating a hazard.

In Gorringe, the allegation did not concern a statutory power but a failure to comply with a duty in the Road Traffic Act 1988 (UK) to "carry out a programme of measures designed to promote road safety". ${ }^{36}$ The House of Lords, however, extended the rule in East Suffolk to statutory duties as well as powers. ${ }^{37}$ If the tort of breach of statutory duty could not be established, then there must be a pre-existing relationship (such as assumption of responsibility) or the authority must have made the situation worse by doing something than if it had done nothing. Therefore the rule relied on in Prince that a statutory duty (as opposed to a power) could sound in negligence (as opposed to the breach of statutory duty tort) was effectively abolished in England, although whether this has been followed in New Zealand is not clear.

The supporters of East Suffolk see its resurrection as an affirmation of a theory of tort law in which public authorities should be liable only when a similarly placed private individual would also be liable or where Parliament has expressly or impliedly said so. Otherwise the existence of a statutory duty or power will only be subject to judicial review, in which the lawfulness of any act or omission can be scrutinised, but no private duty of care will be recognised. Lord Hoffmann, for example, has said extra-judicially that Stovin $v$ Wise and Gorringe re-established the law as it had been before Anns, as it had been in the halcyon days of East Suffolk: ${ }^{38}$

There is no doubt that many academic writers regret what they always call "the retreat from Anns" ... So did some forward-looking judges. The Canadians in particular thought that Anns was an excellent decision and that public authorities should be liable in negligence for not exercising statutory powers when the courts

\footnotetext{
${ }^{34}$ Ibid, at [14].

${ }^{35}$ Section 79(1) (controlling part) of Highways Act 1980 (UK):

Where, in the case of a highway maintainable at the public expense, the highway authority for the highway deem it necessary for the prevention of danger arising from obstruction to the view of persons using the highway to impose restrictions with respect to any land at or near any corner or bend in the highway or any junction of the highway with a road to which the public has access, the authority may, subject to the provisions of this section, serve a notice, together with a plan showing the land to which the notice relates ...

${ }^{36}$ Section 39(2) Highways Act 1908 (UK).

${ }^{37}$ Nolan, above $\mathrm{n} 1$.

${ }^{38}$ Lord Hoffmann, above n 1, at [14]; see also Law Commission, above n 8, at [3.20].
} 
thought it would have been reasonable for them to do so. But that is not the law in England.

Nolan has also argued that Gorringe brought tort law back to the position in East Suffolk. Even in the presence of a statutory power or duty, there can only be liability for the same reasons as under private law: where the defendant makes the situation worse, where there is an assumption of duty or where there is the separate tort of breach of statutory duty. ${ }^{39}$ Nolan has criticised the English Court of Appeal decision in East Berkshire, which recognised a duty of care to protect children at risk of abuse as an unfortunate exception to this position. ${ }^{40}$ This decision brought English law into line with the duty of care recognised in New Zealand since Prince, but as Nolan points out it is inconsistent with the current English approach associated in this thesis with East Suffolk. In Prince and East Berkshire, there were no pre-existing relationships, and the authorities' negligence did not put the child abuse victims in a worse position in the East Suffolk sense. They merely failed to put the plaintiff in a better position. Nolan suggests that the Court of Appeal's decision was based on an approach which favours policy over principle: ${ }^{41}$

The most likely explanation for these apparent discontinuities is the fact that judicial reasoning in duty of care cases is increasingly dominated by arguments of public policy ... increasingly judges and commentators think in terms of police cases, social services cases, highways cases and so forth, rather than conceiving of negligence law - or even the negligence liability of public authorities - as a unified whole.

However context does matter: the child abuse cases should be treated differently from, say, the highway cases, because there is the extra aspect of the community duty to protect children which needs to be vindicated. In the East Suffolk approach the argument that the statutory duties reflect community duties points against a "private" cause of action. Under the vindicatory approach, however, tort law as embraced as an important part of the public law, and the "public" aspect of the statutory duty is seen as support for the imposition of liability.

\section{E The East Suffolk Approach and Parliamentary Intention}

In Gorringe, the East Suffolk rule was extended to statutory duties as well as statutory powers. This is consistent with a shift from distinguishing powers and duties to a new distinction between narrow duties for the benefit of a limited class, and everything else, including statutory powers and also wider duties, sometimes called "target

\footnotetext{
${ }^{39}$ Donal Nolan, above $\mathrm{n} 1$.

${ }^{40}$ D v East Berkshire Community NHS Trust [2003] EWCA Civ 1151, [2004] QB 558. Discussed in chapter three at text to footnote 48 .

${ }^{41}$ Donal Nolan, above n 1, at 287.
} 
duties". ${ }^{42}$ The narrow duties are actionable, either because it can be inferred that Parliament intended breach of the duty to sound in damages, or more usually because Parliament has expressly said so. "Target duties" on the other hand are only susceptible to judicial review on this approach.

This approach to what could loosely be described as "statutory torts" (where either the statute includes a damages section or the breach of statutory duty tort is established) relies on Parliamentary intention to decide whether a statutory duty actionable: if an intention cannot be discerned, the duty is assumed to be exclusively in the general interest. As discussed above, the test for the breach of statutory duty tort is whether there is a Parliamentary intention to confer a remedy in damages, which is more likely where there is no remedy provided in the statute and where the statutory duty is owed to a clearly defined class of plaintiffs. ${ }^{43}$ The bright line distinction between "statutory torts" and all other statutory duties and powers has led in England to an approach in which it is assumed that Parliament intended there to be no remedy if a "statutory tort" is not established. Lord Scott adopted this approach in Gorringe: $:^{44}$

In my opinion, if a statutory duty does not give rise to a private right to sue for breach, the duty cannot create a duty of care that would not have been owed at common law if the statute were not there. If the policy of the statute is not consistent with the creation of a statutory liability to pay compensation for damage caused by a breach of the statutory duty, the same policy would, in my opinion, exclude the use of the statutory duty in order to create a common law duty of care that would be broken by a failure to perform the statutory duty.

There are two problems with this reasoning. The first is that the lack of an intention to provide compensation is not the same as an intention not to provide compensation. The second, more fundamental problem is that it relies on the Parliamentary intention test for the tort of breach of statutory duty. Fleming criticised an approach which purports to find an implied intention where Parliament has not included a remedy provision as: ${ }^{45}$

... a barefaced fiction because, consonant with accepted canons of statutory interpretation, the legislature's silence on the question of civil liability rather points to the conclusion that it either did not have it in mind or deliberately omitted to provide for it.

\footnotetext{
${ }^{42}$ For more on the term "target duty" see Catherine Callaghan "What is a "Target Duty'?" (2000) 5 JR 184.

${ }^{43} X v$ Bedfordshire, above $\mathrm{n} 12$.

${ }^{44}$ Gorringe, above n 10, at [71] See also Lord Hoffmann's speech in the same case at [32], where he made a similar point but perhaps without being quite so absolute.

${ }^{45}$ John G Fleming The Law of Torts (9th ed, Sweet \& Maxwell Ltd, London, 1998) at 128.
} 
This difficulty led the Supreme Court of Canada to abolish the tort. ${ }^{46}$

The distinction between actionable duties and "target duties" is also problematic because there is no obvious compelling reason for making narrow duties actionable as opposed to "target duties": it is as possible to suffer loss as a consequence of a breach of a "target duty" as it is to suffer loss when a narrow duty is breached. An important general duty might require vindication just as much as a narrowly defined but relatively trivial duty.

In New Zealand the position of the tort of breach of statutory duty is unclear. It has been argued that the New Zealand courts do not see much merit in the tort, ${ }^{47}$ however it has resurfaced in Altimarloch ${ }^{48}$ The tort is not usually necessary, as almost all personal injury cases (including those with which the tort is most associated, workplace injury) are covered by New Zealand's accident compensation scheme. ${ }^{49}$ The tort is possibly not so much abolished in New Zealand as largely redundant.

\section{F Vindicating the Negligent Exercise of Statutory Power through Tort Law}

Where a public authority is sued not for loss, however, but to vindicate a wrong, the breach of statutory duty tort might have some use. For example, in Prince the allegation was that the public authority breached its duty to initiate a prompt inquiry into the complaint it received that the plaintiff was being abused by his adoptive parents. This was a breach of the defendant's statutory duties. If the breach of statutory duty tort had been established, that might have included a vindicatory purpose, to which vindicatory damages arguably could have been attached.

The breach of statutory duty tort might be a useful vindicatory cause of action in tort law. However, it has not been a popular tort with judges: the House of Lords struck it out in Bedfordshire, it is largely obsolete in New Zealand, and it has been judicially abolished in Canada.

The alternative approach is to vindicate the negligent exercise of statutory power to protect children through the tort of negligence. This is contrary to the East Suffolk approach, favoured by Lord Hoffmann and Nolan. The East Suffolk approach does

\footnotetext{
${ }^{46}$ The Queen v Saskatchewan Wheat Pool [1983] 1 SCR 205.

${ }^{47}$ See Geoff McLay “Antipodean Perspectives on Child Welfare Tort Claims against Public Authorities in Duncan Fairgrieve and Sarah Green (eds) Child Abuse Tort Claims Against Public Bodies: A Comparative Law View (Ashgate, Aldershot, 2004) 117, at 119, citing Attorney-General v Carter [2003] 2 NZLR 160 (CA). Cf Neil Foster "The Merits of the Civil Action of Breach of Statutory Duty" (2011) 33 Syd LR 67.

${ }^{48}$ Altimarloch Joint Venture Ltd v Moorhouse HC Blenheim CIV-2005-406-91, 3 July 2008, at [146], relying on Carter, ibid, for the "opposite effect" Leave to appeal to the Supreme Court has been given: [2010] NZSC 82.

${ }^{49}$ Stephen Todd (ed) The Law of Torts in New Zealand (5th ed, Brookers, Wellington, 2009) at 396.
} 
not seem to have been adopted in New Zealand, ${ }^{50}$ and there are good reasons for this, as the discussion above has tried to demonstrate. The approach assumes that statutes in the general interest should not be actionable in damages by private individuals. However, the general public may have an interest in seeing a wrong vindicated through an award of damages to the plaintiff. This is true of the child abuse cases, where the statutes are both in the general interest and include duties to a limited class of plaintiffs. To return to Tipping J's dictum in Taunoa, both the immediate victim, and the general public have an interest in seeing the negligent exercise of statutory power vindicated.

\section{G Justiciability}

The final part of this chapter considers what might be described as an alternative way of dealing with an issue which runs through the debates outlined above: whether it is appropriate for courts to deal at all with allegations about the way public authorities exercise statutory power. It is sometimes said that before the courts will decide whether there is a duty of care against a public authority, there is a prior hurdle to be passed over called "justiciability". A case is justiciable if the issues are appropriate ones for the judiciary to consider; in other words the issues are not too political or outside the courts' competency.

To some extent the justiciability approach has been overtaken by the positions, discussed above. However, justiciability is still sometimes argued as a separate point to the duty issue in public authority cases, and the policy and operational decisions test which is part of the justiciability approach is still applied (although possibly as a policy factor at the second stage of the Anns test). It also retains support in the textbooks on public authority liability as a separate stage in the analysis. ${ }^{51}$ It is therefore analysed in a separate section of its own, with special emphasis on how a vindicatory approach might alter the focus of the justiciability tests.

\section{The rationales}

There are two main rationales for the justiciability rule. The first concerns Parliamentary sovereignty. Where an act or omission can be described as within the defendant's statutory discretion, it can be argued that Parliament made a sovereign decision to entrust the decision to that specific authority, and it is not for the judiciary

\footnotetext{
${ }^{50}$ There is of course no explicit rejection of the approach, but even the relatively conservative majority judgment in Couch v Attorney-General (on appeal from Hobson v Attorney-General) [2008] NZSC 45, [2008] 3 NZLR 725 there is nothing approaching the rigidity in Lord Hoffmann's speeches.

${ }^{51}$ Cherie Booth QC and Dan Squires The Negligence Liability of Public Authorities (Oxford, Oxford University Press, 2006), at ch 2; Stanton, above n 13, at ch 3, see for example the discussion at 103.
} 
to scrutinise the defendant and effectively second-guess Parliament. ${ }^{52}$ The other rationale is concerned with competency: there are some issues which the judiciary is not very good at determining, and there may be institutions better able to deal with the matter.

In 2010 the English Court of Appeal was confronted with a justiciability argument in Connor $v$ Surrey County Council. ${ }^{53}$ It was alleged that the defendant council had failed to intervene effectively in the plaintiff head teacher's dispute with her board of trustees. The defendant argued that this concerned an exercise of a statutory discretion which was not justiciable, and Laws LJ dealt with this part of the law of negligence at length. He identified both the rationales described above and held that it is the second which currently holds sway: "The competence of the court, rather than the authority of the legislature, is made the test of what is justiciable by way of a private law claim." 54 This was a "pragmatic" test based on the competency of the court and the sorts of policies involved in the claim: "There are policies and policies. The courts may be more, or less, competent to decide on the merits of some than on the merits of others." 55

In New Zealand, justiciability does not appear to be a separate stage of inquiry prior to the duty of care issue. However, the same pragmatic concern whether the issue is one which the courts are able to adjudicate is likely to be relevant to the second stage of the Anns test, whether there are any policy considerations which point away from a duty of care. For example, New Zealand judges continue to take into account whether the alleged negligence is a matter of high policy (which is not justiciable) or merely an administrative blunder. ${ }^{56}$ This distinction (discussed in more detail below) is part of the justiciable approach in England.

\section{The different tests}

In asking the question whether a matter is suitable for judicial determination, judges have applied two main tests. The first is the policy-operational test, which as mentioned above continues to be used in New Zealand. The second is whether the alleged negligence was Wednesbury unreasonable and therefore outside the statutory discretion. This test was at one stage favoured by Lord Hoffmann. ${ }^{57}$

\footnotetext{
${ }^{52}$ See $X v$ Bedfordshire, above $\mathrm{n} 12$, at 736.

${ }^{53}$ Connor v Surrey County Council [2010] EWCA Civ 286, [2011] QB 429.

${ }^{54} \mathrm{Ibid}$, at [92]. The Parliamentary sovereignty argument is at [82].

55 Ibid, at [92].

${ }^{56}$ See Elias CJ and Anderson J in Couch, above n 50, discussed below.

${ }^{57}$ See his speech in Stovin v Wise, above n 30.
} 
The starting point for consideration of these tests is usually Lord Browne-Wilkinson's judgment in $X v$ Bedfordshire. Unfortunately, the judgment is "dense" a discussion than a setting out of clearly defined rules.

\section{The policy-operational test}

Lord Brown Wilkinson first applied the policy/operational test. He held that the allegations in $X v$ Bedfordshire "would not require the court to consider policy matters which are not justiciable." He described the non-justiciable policy issues in this way: ${ }^{59}$

In deciding whether or not this requirement is satisfied, the court has to assess the relevant factors taken into account by the authority in exercising the discretion. Since what are under consideration are discretionary powers conferred on public bodies for public purposes the relevant factors will often include policy matters, for example social policy, the allocation of finite financial resources between the different calls made upon them or ... the balance between pursuing desirable social aims as against the risk to the public inherent in so doing. It is established that the courts cannot enter upon the assessment of such "policy" matters.

The scarce allocation of resources is usually seen as a textbook example of a nonjusticiable policy issue. If the plaintiff's allegation is that the Crown's under-funding caused a failure in the system which prevented the plaintiff being rescued from abusive parents, the claim is likely to fail as raising non-justiciable issues. However, the allegation in such cases is usually more concrete than that. In White, for example, Miller J found that the social workers had failed to speak to children alone when they were under court ordered supervision. There may have been an underlying problem with the resources available to the defendant, but it will often be possible to cast this as operational negligence.

In Couch, Elias CJ and Anderson J (dissenting in approach) made a similar point. It was alleged that but for the Parole Board's negligence parolee Bell would not have attacked the plaintiff. In their joint decision, Elias CJ and Anderson $\mathbf{J}$ suggested that what may at first seem like an attack on the government's resource allocation policy may on closer inspection (at trial) be more accurately described as an "administrative blunder": ${ }^{60}$

Counsel for the Attorney-General has throughout acknowledged that the probation supervision of Bell was deficient. The general picture of an underresourced and overwhelmed Probation Service, described by the statement of claim, has not been

\footnotetext{
${ }^{58}$ Connor, above n 53, at [79].

${ }^{59} X v$ Bedfordshire, above $\mathrm{n} 12$, at 737.

${ }^{60}$ Couch, above n 50, at [12].
} 
resisted ... For the purposes of considering fault or any policy reasons why liability may not ultimately be appropriate, it cannot be assumed that the state of the office was a result of high policy assessment of priorities (which might be a consideration against duty of care or its breach, depending on the view taken of the statutory obligation) rather than administrative blunders (which may raise no such concerns of policy or excuse).

Such blunders are appropriately vindicated through litigation, since discovery can help to reveal what went wrong. However, discovery is less likely to disclose government decisions concerning the allocation of resources for public authorities such as child welfare services.

\section{Wednesbury unreasonableness}

The second main justiciability test is whether the act or omission is so unreasonable, applying the Wednesbury threshold, that it cannot be said to be within the statutory power created by Parliament. The standard of Wednesbury unreasonableness is controversial: the label comes from the case Associated Provincial Picture Houses Ltd $v$ Wednesbury Corporation ${ }^{61}$ in which Lord Greene MR observed that a decision may be set aside in judicial review if it could be said that no reasonable statutory authority would have made the decision. The example he gave of a teacher dismissed for having red hair suggests a very high standard.

The rationale of the rule's application in negligence actions is that if the alleged negligence is within the discretion of the statute, the statute provides a defence. Lord Brown-Wilkinson in $X v$ Bedfordshire put it this way: ${ }^{62}$

Where Parliament has conferred a statutory discretion on a public authority, it is for that authority, not for the courts, to exercise the discretion: nothing which the authority does within the ambit of the discretion can be actionable at common law.

However, the application of the high standard in Wednesbury can lead to overkill. When Parliament confers a discretion through statute, it does not follow that Parliament also intends the statute to provide a defence for everything which can be described as within the statutory discretion in judicial review terms but negligent in tort law terms. Perhaps for this reason, the test has not been used by judges much since $X v$ Bedfordshire with the notable exception of Lord Hoffmann. ${ }^{63}$

\footnotetext{
${ }^{61}$ Associated Provincial Picture Houses Ltd v Wednesbury Corpn [1948] 1 KB 223 (CA).

${ }^{62} \mathrm{X} v$ Bedfordshire, above n 12, 737.

${ }^{63}$ See Barrett v Enfield London Borough Council [2001] 2 AC (HL), at 586, Phelps v Hillingdon London Borough Council [2001] 2 AC 619 and Lord Steyn in Gorringe, above n 10.
} 
Lord Hoffmann applied the Wednesbury test in Stovin v Wise. In Stovin Lord Hoffmann held that the allegation that the defendant had failed to exercise its statutory power to make the road safer was not actionable because it was an omission and there was no pre-existing duty between the plaintiff and defendant. However, he went on to hold that the negligence was not actionable because it was not public law unreasonable and therefore not beyond the discretion of the authority. This assumes that a public authority can be liable for a failure to exercise a statutory power even though there is no pre-existing relationship or the tort of breach of statutory duty, an assumption Lord Hoffmann was quick to recant in the later case Gorringe: ${ }^{64}$

... misunderstanding seems to have arisen because the majority judgment [in Stovin] goes on to discuss, in the alternative, what the nature of such a duty might have been if there had been one. It suggests that it would have given rise to liability only if it would have been irrational in a public law sense not to exercise the statutory power to do the work. And it deals with this alternative argument by concluding that, on the facts, there had been no breach even of such a duty. The suggestion that there might exceptionally be a case in which a breach of a public law duty could found a private law right of action has proved controversial and it may have been ill-advised to speculate upon such matters.

On this approach Wednesbury unreasonableness is never relevant. If the tort of breach of statutory duty is not established, there is no pre-existing relationship and the defendant does not make the plaintiff worse off in the East Suffolk sense, the defendant will not be liable whether or not their decision is a breach of public law.

Other judges have also distanced themselves from the severe Wednesbury standard. In Barrett (decided in between Stovin and Gorringe), Lord Hutton limited the Wednesbury unreasonableness test to complaints that a statutory power was not exercised. ${ }^{65}$ Barrett was another strike out action in which the plaintiff had been removed from his parents shortly after his birth and placed in the care of various foster parents and state-owned care facilities. The defendant argued that its decision could not be said to be Wednesbury unreasonable, relying on the dicta in Stovin v Wise by Lord Hoffmann. Lord Hutton held that as Stovin was concerned with the failure to exercise a statutory power, it was not relevant to Barrett, in which the complaint was about the way the power was exercised. Justiciability would therefore only apply to omissions, rather than where it is alleged that the defendant exercised the statutory power in a way that caused the plaintiff loss. Lord Steyn repeated part of

\footnotetext{
${ }^{64}$ Gorringe, above n 10, at 26. See also Lord Hoffmann, above n 38, at [13].

${ }^{65}$ Barrett, above n 63, at 586.
} 
Lord Hutton's speech in his own reasons in Gorringe, observing that these had "qualified" Lord Hoffmann's introduction of the Wednesbury standard in Stovin. ${ }^{66}$

The current status of the Wednesbury test is therefore unclear in England. Where there is a pre-existing relationship or the defendant makes the plaintiff worse off in the East Suffolk sense, then the test is not applicable. For example, in Connor the defendant local body was liable because it was the plaintiff's employer: they had a pre-existing relationship which meant that the defendant owed the plaintiff a common law duty in the way it exercised its statutory authority. However, in general there seems to be a retreat from the stringent requirement of Wednesbury, and disinterest in applying public law standards in tort law.

\section{H Summary}

The Wednesbury test seems unpopular with judges in both England and New Zealand, perhaps because it sets an overly high standard. The policy operational test, however, continues to be used, for example by Elias CJ and Anderson $\mathrm{J}$ in Couch. It can be a useful tool in attempting to answer the question whether an allegation is beyond the competence of the courts. This is most likely where the pleadings concern the allocation of scarce resources. If the complaint concerns funding, litigation is unlikely to be able to vindicate the underlying wrong. The allegation can, however, usually be rephrased as an administrative blunder. Such wrongs are well within the competence of the courts.

Aside from the justiciability test, this chapter has been chiefly concerned with the conservative East Suffolk approach to liability for the way statutory power is exercised. This approach considers that statutes are in the public interest, and that this excludes private individuals having an interest which is actionable in damages. Under the vindicatory approach, however, the public interest is seen as a reason for making public authorities liable, not a reason against liability. In the child welfare cases, while the children are the immediate victims and have a private interest in seeing their wrongs vindicated, the wider public also has an interest in making sure that the breach of the community obligation to look after children is recognised.

\footnotetext{
${ }^{66}$ Gorringe, above n 10, at [4].
} 


\section{Conclusion}

This thesis has argued that vindicatory damages should be available in tort law, including negligence, to mark wrongs where compensatory damages are insufficient to vindicate the wrong or because they are impossible to quantify in any meaningful way. The child welfare cases were analysed as an example of this. The plaintiffs have framed their loss in these cases by emphasising their lack of employment, their alcohol addictions and sometimes by pleading a history of broken relationships. Although these may well be the result of the child abuse which the plaintiffs want to hold the government responsible for, it has usually been possible for the defendants to point to other possible causes of the plaintiffs' sad lives. Apart from the difficulty of disentangling the multiple possible causes, quantifying the loss is inevitably artificial because of the nature of the loss itself. Lack of employment, for example, is usually dealt with through social welfare assistance. However, although judges may be unable to quantify the plaintiffs' loss, the courts might usefully be able to mark the wrong suffered through an award of vindicatory damages, which would also enable the facts leading to the wrong to emerge through the litigation process.

Part of the focus in this thesis has been on how vindicatory damages reflect a public law aspect to the damages award. Where the government is the defendant and the wrong concerns constitutional rights, as in actions for breach of the New Zealand Bill of Rights Act 1990 (NZBORA), or where there is a wider community obligation, like the duty to take care of children in the negligence cases, the public has an interest in seeing the wrong vindicated. Vindicatory damages in these cases serve a wider purpose in addition to remedying the immediate victim: society as a whole benefits from having the wrong vindicated.

This thesis has focused on government liability, but wrongs between private individuals may also require vindication. The wrongful birth cases already provide a good example of this, where the plaintiff's autonomy interest (which includes the decision not to have any more children) is undermined by the defendant's negligence. In many of the child welfare cases the defendant might not be a public authority but a private sector child care institution, but it might still be appropriate to mark the defendant's responsibility through vindicatory damages. A further example is elder abuse, which might also engage wider community obligations although the defendant might be in either the public or the private sector.

In many of the cases analysed in this thesis, it was alleged that the Crown was vicariously liable for its employees or foster parents. While vindicatory damages for

vicarious liability might seem incongruous because liability is imposed whether or not the defendant is at fault, an analysis of the child welfare cases suggests that the courts 
do not ignore the relationship of the plaintiff and defendant when imposing vicarious liability. It was argued in chapter six that these would be better framed as liability for breach of a non-delegable duty, but in the alternative that where liability is imposed because of the relationship between the defendant and plaintiff, this could form a subset of vicarious liability, in which vindicatory damages would be appropriate.

In other cases liability is imposed for the defendant's own negligence, for example where the Crown negligently fails to investigate a complaint it receives that a child has been abused or is in danger of being abused. In these cases, distinct issues arise concerning liability for omissions and liability for the way a statutory power is exercised (or a statutory duty is breached). It was argued in chapters seven and eight that thinking of liability as vindicating a wrong rather than shifting loss may help in understanding the way negligence has been developed to accommodate these cases.

Making public authorities liable for a failure to exercise a statutory power puts them in a different position from private individuals, who are usually not liable for omissions in order to protect their autonomy, and who typically lack special statutory powers. Although according to the equality principle public authorities and private individuals should to be subject to exactly the same tortious liabilities, Prince and East Suffolk suggest that this principle is not always applied. One explanation is that public authorities are representative of the wider community, whose duties to protect children are breached when the authorities fail to exercise their powers. Although the statutes which provide these powers are intended to benefit a specific class (the children), the general public also has in interest in seeing the statutory duties complied with. For example it is the duty of the Chief Executive of Child Youth and Family Services in New Zealand "to take such positive and prompt action and steps" as will "promote the well-being of children, young persons, and their families and family groups". This duty is intended to protect the interests of children, but it is also in the interest of the wider community.

Vindicatory damages are a well recognised part of NZBORA remedies, but they are more controversial when applied in tort law. However, not all awards in tort law are compensatory, as nominal, aggravated and exemplary damages demonstrate. These all have an element of vindication to them, although they are not identical to the separate vindicatory damages award advanced in this thesis. Like vindicatory damages in NZBORA, they should not be barred in New Zealand by the accident compensation scheme.

Whether vindicatory damages would be available would depend on the underlying right or duty, the consequences of the wrong and whether other remedies were sufficient to provide vindication. Quantifying the damages will not be easy, but a 


\section{Chapter IX Conclusion}

body of cases should build up gradually over time to provide appropriate guidance. Although determining quantum will be an issue, the current practice of calculating the plaintiff's loss based on evidence such as lost income leads judges into difficulties that are better avoided. Calculating vindicatory damages is made easier by the growing body of damages cases for human rights statutes, which judges will be able to draw on in developing tortious vindicatory damages. 


\section{Bibliography}

\section{Bibliography}

\section{Cases}

\section{A New Zealand}

Av Roman Catholic Archdiocese of Wellington [2007] 1 NZLR 536 (HC).

A v Roman Catholic Archdiocese of Wellington [2008] NZCA 49, [2008] 3 NZLR 289.

Altimarloch Joint Venture Ltd v Moorhouse HC Blenheim CIV-2005-406-91, 3 July 2008.

Ashley v Chief Constable of Sussex [2008] UKHL 25, [2008] 1 AC 962 (HL).

Attorney-General v Carter [2003] 2 NZLR 160 (CA).

Attorney-General v Chapman [2011] NZSC 110.

Attorney-General v Niania [1994] 3 NZLR 106 (HC).

Attorney-General v Prince and Gardner [1998] 1 NZLR 262 (CA).

B v Attorney-General [1999] 2 NZLR 296 (CA).

B v Attorney-General [2004] 3 NZLR 145 (PC).

Re Chase [1989] 1 NZLR 325 (CA).

Comerford-Parker v Accident Compensation Corporation [2011] NZAR 481 (HC).

Couch v Attorney-General (on appeal from Hobson v Attorney-General) [2008] NZSC 45, [2008] 3

NZLR 725.

Couch v Attorney-General (No 2) (on appeal from Hobson v Attorney-General) [2010] NZSC 27,

[2010] 3 NZLR 149.

Cox \& Coxon Ltd v Leipst [1999] 2 NZLR 15 (CA).

Daniels v Thompson [1998] 3 NZLR 22 (CA).

Donselaar v Donselaar [1982] 1 NZLR 97 (CA).

Dunlea v Attorney-General [2000] 3 NZLR 136 (CA).

East Agriculture Ltd v Manawatu-Wanganui Regional Council HC Palmerston North CIV-2008-454317 September 2011.

Falwasser v Attorney-General [2010] NZAR 445 (HC)

Gv Auckland Hospital Board [1976] 1 NZLR 638 (SC).

Horsburg v NZ Meat Processors Industrial Union of Workers [1988] 1 NZLR 698 (CA).

Howse v Attorney-General SC Palmerston North, A 132/75, 22 December 1977.

Huljich v Hall [1973] 2 NZLR 279 (CA).

JMM v Legal Services Agency HC Wellington CIV-2010-485-1306, CIV-2010-485-1375, CIV-2010485-1630, CIV-2010-485-1740, CIV-2010-485-1961, CIV-2010-485-2527, CIV-2010-485-1559, 14 April 2011.

Knight v Crown Health Financing Agency HC Wellington CIV-2005-485-2678, 16 November 2007. Legal Services Agency v W HC Wellington CIV-2009-485-2191, CIV-2010-404-78, 21 April 2010. Legal Services Agency v LAE HC Wellington CIV-2009-404-3399, CIV-2009-404-3400, CIV-2009- 


\section{Bibliography}

404-3401, 6 August 2009.

Manga v Attorney-General [2000] 2 NZLR 65 (HC).

McCallion v Dodd [1966] NZLR 710 (CA).

Murray v Gebbie [2009] NZAR 630 (HC).

North Shore City Council v Body Corporate 188529 [2010] NZSC 158, [2011] 2 NZLR 289 [Sunset

Terraces].

Pettersson v Royal Oak Hotel Ltd [1948] NZLR 136 (CA).

Prince v Attorney-General [1996] 3 NZLR 733 (HC).

$S$ v Attorney-General [2003] 3 NZLR 450 (CA).

Simpson v Attorney-General [1994] 3 NZLR 667 (CA) [Baigent's Case].

Sivasubramaniam v Yarrall [2005] 3 NZLR 268 (HC).

$T v H$ [1995] 3 NZLR 37 (CA).

Taylor v Beere [1982] 1 NZLR 81 (CA).

Taunoa v Attorney-General [2007] NZSC 70, [2008] 1 NZLR 429.

Timmins v Legal Aid Review Panel [2004] 1 NZLR 708.

van Soest v Residual Health Management Unit [2000] 1 NZLR 179 (CA).

Wv Attorney-General [1999] 2 NZLR 709 (CA).

Wilding v Attorney-General [2003] 3 NZLR 787 (CA).

Wilson \& Horton Ltd v Attorney-General [1997] 2 NZLR 513 (CA).

White v Attorney-General HC Wellington CIV-1999-485-85, CIV-2001-485-864, 28 November 2008.

White v Attorney-General [2010] NZCA 139.

Wv Attorney-General [2010] NZSC 69, (2010) 19 PRNZ 921.

\section{B England}

Anns v Merton London Borough [1978] AC 728 (HL).

Ashby $v$ White (1703) 2 Ld Raym 938.

Associated Provincial Picture Houses Ltd v Wednesbury Corp [1948] 1 KB 223 (CA).

B v London Borough of Ealing [2008] EWHC 1262 (QB).

Barrett v Enfield London Borough Council [2001] 2 AC (HL).

Cassell \& Co Ltd v Broome [1972] AC 1027 (HL),

Chester v Afshar [2004] UKHL 41, [2005] 1 AC 134.

Connor v Surrey County Council [2010] EWCA Civ 286, [2011] QB 429.

Constantine v Imperial Hotels Ltd [1944] KB 693 (QB).

D v East Berkshire Community NHS Trust [2003] EWCA Civ 1151, [2004] QB 558 (CA).

D v East Berkshire Community Health [2005] UKHL 23, [2005] 2 AC 373.

East Suffolk Rivers Catchment Board v Kent [1941] AC 74 (HL).

Gorringe v Calderdale Metropolitan Council Borough [2004] UKHL 15, [2004] 1 WLR 1057.

Hedley Byrne and Co Ltd v Heller and Partners Ltd [1964] AC 463 (HL).

Lister v Hesley Hall Ltd [2001] UKHL 22, [2002] 1 AC 215.

Livingstone v Reywards Coal Co (1880) LR 5 App Cas 25 (HL).

Lloyd v Grace, Smith \& Co [1912] AC 716 (HL). 


\section{Bibliography}

MacFarlane v Tayside Health Board [2002] 2 AC 59 (HL).

Murphy v Brentwood District Council [1991] 1 AC 398 (HL).

O’Rourke v Camden London Borough Council [1998] AC 188 (HL)

Parkinson v St James and Seacroft University Hospital NHS Trust [2001] EWCA Civ 530, [2002] QB

266.

Phelps v Hillingdon London Borough Council [2001] 2 AC 619 (HL).

Pierre v Doncaster Metropolitan Borough Council [2007] EWHC 2968 (QB).

$R$ (Quark Fishing Ltd.) v Secretary of State for Foreign \& Commonwealth Affairs [2003] EWHC 1743.

Rees v Darlington Memorial Hospital NHS Trust [2004] 1 AC 309, [2004] 1 AC 309(HL).

Rooke v Viscount Chelmsford [1965] 1 QB 248 (CA).

Rookes v Barnard [1964] AC 1129 (HL).

Sheppard v Glossop Corporation [1921] 3 KB 132 (CA).

Sidaway v Board of Governors of the Bedlam Royal Hospital [1985] AC 871 (HL).

Smith v Littlewoods Organisation Ltd [1987] AC 241 (HL).

Stovin v Wise [1996] AC 923 (HL).

Watkins v Secretary of State for the Home Department [2004] EWCA Civ 966, [2005] QB 883.

Watkins v Secretary of State for the Home Department [2006] UKHL 17, [2006] 2 AC 395.

White and Others $v$ Chief Constable of South Yorkshire [1992] 2 AC 455 (HL).

Wilkes $v$ Wood (1763) Lofft 1.

$X$ (Minors) v Bedfordshire [1995] 2 AC 633 (HL).

Yetkin v Mahmood [2010] EWCA Civ 776, [2011] QB 827.

\section{European Court of Human Rights}

Osman v United Kingdom (2000) 29 EHRR 245 (ECtHR).

Z v United Kingdom (2002) 34 EHRR 3 (ECtHR).

\section{Canada}

KLB v British Columbia 2003 SCC 51, [2003] 2 SCR 403.

MB v British Columbia 2003 SCC 53, [2003] 2 SCR 477.

Bazley v Canada [1999] 2 SCR 534.

Blackwater v Plint 2005 SCC 58, [2005] 3 SCR 3.

EDG v Hammer 2003 SCC 52, [2003] 2 SCR 459.

HL v Canada (Attorney-General) 2005 SCC 25, [2005] 1 SCR 401.

Mustapha v Culligan of Canada Ltd 2008 SCC 27, [2008] 2 SCR 114.

The Queen v Saskatchewan Wheat Pool [1983] 1 SCR 205.

$R v$ Imperial Tobacco Canada [2011] SCC 42.

Vancouver (City) v Ward 2010 SCC 27, [2010] 2 SCR 28.

\section{E Australia}

Cattanach v Melchior (2003) 199 ALR 131 (HC).

New South Wales v Ibbett [2006] HCA 57, (2006) 229 CLR 638. 


\section{Bibliography}

State of South Australia v Lampard-Trevorrow [2010] SASC 56, (2010) 106 SASR 331.

Stuart v Kirkland-Veenstra (2009) 237 CLR 215 (HC).

\section{F South Africa}

Fose v Minister of Safety and Security [1997] 3 SA 786 (CC).

\section{Trinidad and Tobago}

Maharaj v Attorney-General of Trinidad and Tobago (No 2) [1979] AC 385 (PC).

\section{Articles and Chapters of Books}

Anderson, Stuart "'Grave injustice': the insecure foundations of crown liability for torts in New Zealand" (2009) 12 Otago LR 1.

Atkin, Bill and McLay, Geoff "Suing Child Welfare Agencies: A Comparative View from New Zealand" in John Dewar and Stephen Parker (eds) Family Law: processes practices pressures (Hart Publishing, Oxford, 2003) 161.

Beever, Allan “The Structure of Aggravated and Exemplary Damages” (2003) 23 OJLS 87.

Birks, Peter "Harassment and Hubris: The Right to an Equality of Respect" (1997) 32 Irish Jurist 1.

Callaghan, Catherine “What is a 'Target Duty’?” (2000) 5 JR 184.

Charters, Claire "The Foreshore and Seabed Act 2004 and Crown Fiduciary Duties to Maori: How does it Compare and What Have Maori Lost?" in Claire Charters and Andrew Erueti (eds) Maori Property Rights and the Foreshore and Seabed: The Latest Frontier (VUW Press, Wellington, 2007) 143.

Cooper Legal “2"2 Quarter 2011” (2011)<www.sonjacooperlaw.co.nz>.

Eekelaar, John “Are Parents Morally Obligated to Care for Their Children? (1991) 11 OJLS 340.

Eekelaar, John "The Importance of Thinking that Children Have Rights" in Philip Alston, Stephen Parker and John Seymour (eds) Children, Rights and the Law (Oxford University Press, Oxford, 1992) 221.

Eekelaar, John "Parental Responsibility: State of Nature or Nature of the State? (1991) 13 JSWFL 37.

Feldthusen, Bruce, Hankivsky, Olena and Greaves, Lorraine "Therapeutic Consequences of Civil Actions for Damages and Compensation Claims by Victims of Sexual Abuse" (2000) 12 Can J Women \& L 66.

Freeman, Michael “Taking Children's Rights More Seriously” in Michael Freeman (ed) The Moral Status of Children: Essays on the Rights of the Child (Kluwer Law International, The Hague, 1997).

Giliker, Paula "A 'new' head of damages: damages for mental distress in the English law of torts" (2000) 20 Legal Stud 19.

Foster, Neil "The Merits of the Civil Action of Breach of Statutory Duty" (2011) 33 Syd LR 67. Handford, Peter “Intentional Negligence: A Contradiction in Terms?” (2010) 32 Syd L Rev 29

Henaghan, Mark "Editorial: Suing for an appalling childhood” (1997) 2 BFLJ 174.

Hershovitz, Scott "Harry Potter and the Trouble with Tort Theory" (2010) 63 Stan L Rev 67.

Lord Hoffmann "Reforming the Law of Public Authority Negligence" (2009) The Bar Council $<$ www.barcouncil.org.uk>

Hohfeld, WN “Some Fundamental Legal Conceptions as Applied in Judicial Reasoning” (1913) 23 Yale LJ 16.

Landes, William M and Posner, Richard A "Salvors, Finders, Good Samaritans, and Other Rescuers: An Economic Study of Law and Altruism” (1978) 7 JLS 83.

Laws, Sir John "The limitations of human rights" [1998] PL 254.

Lord Lester of Herne Hill QC “The Impact of the Human Rights Act on Public Law” in Jack Beatson 


\section{Bibliography}

(ed) Constitutional Reform in the United Kingdom: Principles and Practice (Hart Publishing, Oxford, 1998) 105

Linden, AM “Tort Law as Ombudsman” (1973) 51 Can B Rev 155.

Luntz, Harold "Liability of statutory authorities for omissions" (1998) 6 TLJ 107.

Martin, Bevan "Exemplary Damages" in Blanchard J Civil Remedies (2nd ed, Brookers, Auckland, 2011)

McGregor, Harvey McGregor on Damages (18th ed Sweet \& Maxwell, London, 2009).

McIntyre, Sheila "Guardians of Privilege: The Resistance of the Supreme Court of Canada to Institutional Liability for Child Sexual Abuse" in Sanda Rodgers, Rakhi Ruparelia and Louise Bélanger-Hardy (eds) Critical Torts (LexisNexis, Markham, 2009).

McLay, Geoff "Antipodean Perspectives on Child Welfare Tort Claims against Public Authorities in Duncan Fairgrieve and Sarah Green (eds) Child Abuse Tort Claims Against Public Bodies: A Comparative Law View (Ashgate, Aldershot, 2004).

McLay, Geoff "Remedies for Breaches of 'Public' Obligation: The Equality Principle Meets the Welfare State and the New Constitutionalism" in Jeff Berryman and Rick Bigwood The Law of Remedies: New Directions in the Common Law (Irwin Law, 2010, Toronto) at 406.

Murphy, John "Judicial Foundations of Common Law Non-Delegable Duties" in Jason W Neyers, Erika Chamberlain and Stephen GA Pitel (eds) Emerging Issues in Tort (Hart Publishing, Oxford, 2007) 369.

Murphy, John "The nature and domain of aggravated damages" (2010) 69 CLJ 353.

Murphy, John "Rights, Reductionism and Tort Law” (2008) 28 OJLS 393.

Neyers, Jason W and Stevens, David "Vicarious Liability in the Charity Sector: an Examination of Bazley v Curry and Re Christian Brothers of Ireland in Canada" (2005) 42 Can Bus LJ 371.

Nolan, Donal "The liability of public authorities for failing to confer benefits" (2011) 127 LQR 260.

Nolan, Donal "New Forms of Damage in Negligence” (2007) 70 MLR 59.

Palmer, Phil and Steele, Jenny "Police Shootings and the Role of Tort" (2008) 71 MLR 801.

Pannick, David and Lester, Anthony “The impact of the Human Rights Act on private law: the knight's move" (2000) 116 LQR 380.

Pearce, David and Halson, Roger "Damages for Breach of Contract: Compensation, Restitution and Vindication" (2008) 28 OJLS 73.

Pollock, Frederick “Lloyd v Grace, Smith \& Co" (1913) 29 LQR 10.

Priel, Dan “A Public Role for the Intentional Torts” (2011) Social Science Research Network $<$ www.ssrn.com>.

Reid, Elspeth "Smith v Littlewoods Organisation Ltd (1985)" in Charles Mitchell and Paul Mitchell (eds) Landmark Cases in the Law of Tort (Hart Publishing, Oxford, 2010) 251.

Rosenberg, David "The Dusting of America: a Story of Asbestos - Carnage, Cover-up, and Litigation HLR" (1968) 99 HLR 1693.

Stapleton, Jane "The gist of negligence: Part 1 Minimal actionable damage" (1988) 104 LQR 213.

Stapleton, Jane "The golden thread at the heart of tort law: Protection of the vulnerable" (2003) 24

ABR 1.

Steele, Iain "Public law liability - the Human Rights Act and beyond" (2005) 64 CLR 8.

Stevens, Robert "Non-delegable Duties and Vicarious Liability” in Jason W Neyers, Erika Chamberlain and Stephen GA Pitel (eds) Emerging Issues in Tort (Hart Publishing, Oxford, 2007).

Stevens, Robert “Why do agents 'drop out'?” [2005] LMCLQ 101.

Varuhas, Jason "A Tort-Based Approach to Damages under the Human Rights Act 1998" (2009) 72 MLR 750.

Wilberg, Hanna "Defensive practice or conflict of duties? Policy concerns in public authority negligence claims” (2010) 126 LQR 420. 


\section{Bibliography}

Windsor, Matthew "Exemplary damages and government liability” [2010] NZLJ 171.

Witzleb, Norman and Carroll, Robyn "The role of vindication in torts damages" (2009) 17 Tort L Rev 16.

Lord Woolf of Barnes "The Human Rights Act 1998 and Remedies” in Mads Andenas (ed) Judicial Review in International Perspective (Kluwer Law International, The Hague, 2000) 429.

\section{Books}

Atiyah, PS Vicarious Liability in the Law of Torts (Butterworths, London, 1967).

Beever, Allan Rediscovering the Law of Negligence (Hart Publishing, Oxford, 2007).

Booth, Cherie QC and Squires, Dan The Negligence Liability of Public Authorities (Oxford, Oxford University Press, 2006).

Butler, Andrew and Butler, Petra The New Zealand Bill of Rights Act: a commentary (LexisNexis, Wellington, 2005).

Cane, Peter Atiyah's Accidents, Compensation and the Law (7th ed, Cambridge University Press, Cambridge, 2006).

Cane, Peter The Anatomy of Tort Law (Oxford University Press, Oxford, 1997).

Cornford, Tom Towards a Public Law of Torts (Ashgate, Aldershot, 2008).

Dicey, Albert V Introduction to the Study of the Law of the Constitution (8th ed, Macmillan, 1915

Dworkin, Gerald Theory and Practice of Autonomy (Cambridge University Press, Cambridge, 1988).

Dworkin, Ronald Life's Dominion: An Argument about Abortion, Euthanasia and Individual Freedom (HarperCollins, London, 1993).

Fleming, John G The Law of Torts (Sweet \& Maxwell Ltd, 1992, 8th ed, London).

Fleming, John G The Law of Torts (9th ed, Sweet \& Maxwell Ltd, London, 1998).

Giliker, Paula Vicarious Liability in Tort: A Comparative Perspective (Cambridge University Press, Cambridge, 2010).

Harlow, Carol State Liability: Tort Law and Beyond (Oxford, Oxford University Press, 2004).

Heuston, RFV and Buckley, RA Salmond and Heuston on the Law of Torts (21st ed, Sweet \& Maxwell, London, 1996).

Hogg, Peter W and Monahan, Patrick J Liability of the Crown (3ed, Carswell, Scarbourgh, 2000).

Jones, Michael A (ed) Clerk \& Lindsell on Torts (20th ed, Sweet \& Maxwell, London, 2010).

Linden, Allen M and Feldthusen, Bruce Canadian Tort Law (9th, LexisNexis, Markham, Ontario, 2011).

Moules, Richard Actions against Public Officials: Legitimate Expectations, Misstatement and Misconduct (Sweet \& Maxwell/Thomson Reuters (Legal) Ltd, London, 2009).

Pollock, Sir Frederick The Law of Torts: A treatise on the principles of obligations arising from civil wrongs in the common law (13th ed, London, Stevens \& Sons Ltd, 1929).

Salmond, John W The Law of Torts (1st, Stevens and Haynes, London, 1907).

Stanton, Keith and others Statutory Torts (Sweet \& Maxwell, London, 2003).

Stevens, Robert Torts and Rights (Oxford University Press, Oxford, 2007).

Todd, Stephen (ed) The Law of Torts in New Zealand (5th ed, Brookers, Wellington, 2009).

Waddams, Stephen Dimensions of Private Law: Categories and Concepts in Anglo-American Legal Reasoning (Cambridge University Press, Cambridge, 2003).

Walton, Christopher (ed) Charlesworth \& Percy on Negligence (Thomas Reuters, London, 2010).

Watts, Peter and Reynolds, FMB Bowstead and Reynolds on Agency (19th ed, Sweet \& Maxwell, London, 1010). 


\section{Bibliography}

\section{Legislation}

\section{A New Zealand}

Accident Compensation Act 2001 (originally the Injury Prevention, Rehabilitation, and Compensation Act 2001).

Accident Rehabilitation and Compensation Insurance Act 1992.

Children and Young Persons Act 1974.

Children, Young Persons, and Their Families Act 1989.

Child Welfare Act 1925.

Crimes Act 1961.

Crown Proceedings Act 1950.

Human Rights Act 1993.

Limitation Act 2010.

New Zealand Bill of Rights Act 1990.

\section{B United Kingdom}

Fatal Accidents Act 1976

The Highway Act 1980.

Human Rights Act 1998.

Land Drainage Act 1930 (UK) 20 \& 21 Geo V c 44.

The Highway Act 1980.

\section{Canada}

The Court of Appeal Act SS 2000 c C-42.1.

Ministry of Transportation and Highways Act RSBC 1979 c 280

\section{$V$ Treaties}

European Convention on Human Rights (opened for signature 4 November 1950, entered into force 3 September 1974).

Convention on the Rights of the Child (opened for signature 20 November 1989, entered Into force 2 September 1990).

\section{Reports}

The Green Paper for Vulnerable Children Every child thrives, belongs, achieves (2011)

$<$ www.msd.govt.nz>.

Law Commission Administrative Redress: Public Bodies and the Citizen (UKLC R322, 2010).

Parliamentary Commissioner for Administration, Maladministration and Redress, HC 112 (1994-5).

Parliamentary and Health Service Ombudsman “A Breach of Confidence: A report by the

Parliamentary Ombudsman on an investigation of a complaint about HM Revenue \& Customs, the

Child Support Agency and the Department for Work and Pensions" (2011)

$<$ www.ombudsman.org.uk $>$. 


\section{Bibliography}

\section{E-mails}

Cooper, Sonja to Neild, David regarding the ex gratia payments in White (19 September 2011). 